Konstantinos Kalogeropoulos

\title{
Vasileios Petrakos: A Life Dedicated to the Service of Greek Archaeology
}

\begin{abstract}
It was undoubtdedly a day of great consequence to Greek archaeology in June 1959 when Vasileios Petrakos was appointed Epimeletes at the Greek Archaeo-

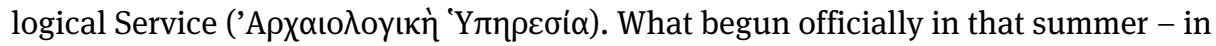
fact actually three years earlier in summer 1956 - now spans 64 years and one spectacular career. This brief essay cannot, of course, address all of Petrakos' contributions to the field of Greek archaeology, but it tries to highlight some of his innumberable interests and talents, to put his work in the proper perspective.
\end{abstract}

\section{Childhood (1932-1950)}

Vasileios Petrakos was born on 7 October 1932 in the harbor town of Peiraieus as the third child in a family of four children (one older brother, one older sister, one younger sister). Both of his parents came to Peiraieus from different parts of Greece. His father, a tailor, who from 1912 to 1922 participated in three consecutive wars (Balkan Wars, World War I and Greco-Turkish War), moved there from Gytheion (Laconia), his mother came from Aidepsos (Euboea). Petrakos' later childhood, that time which constructs someone's individuality, coincided with the Nazi occupation of the Greek mainland (1941-1944). During this period Peiraieus, the town where he was born and grown up, was twice devastated by aerial bombing (1941 by the Germans and 1944 by the Allies). This was a time of fear, terror and confusion characterized by the destruction of homes, loss of beloved persons and separation of families. Petrakos himself was sent with the other children of his family from Peiraieus for safety to Aidepsos. His adolescence corresponded with the Greek Civil War (1946-1949). All these traumatic experiences generated life-long effects on him, as it is evidenced by personal statements, especially in his later work. ${ }^{1}$

Information cited in this article derives either from the honoree's own published work or from personal conversations I had with him. I am grateful to co-editor Mrs. Dora Vassilikou for providing me with the photographs 1-3. Bold numbers in the footnotes refer to the publications of the honoree at the end of the article. Many thanks are also due to Don Evely for polishing my English.

1 Two examples concerning his visual memories from the Nazi occupation, one made in 2013 and

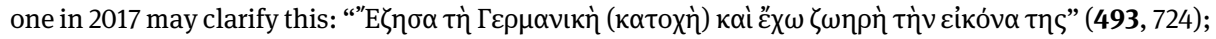

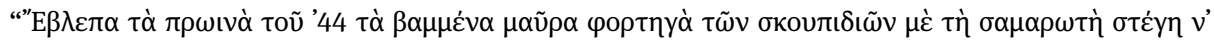

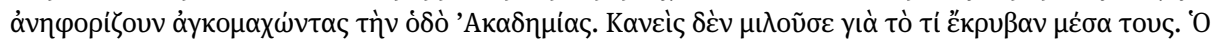

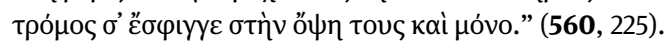

https://doi.org/10.1515/9783110699326-206 


\section{University (1951-1956)}

From 1951 to 1956, i.e. during the Post Civilian War / Early Cold War Era of Greece, Petrakos studied History and Archaeology at the University of Athens. He was educated in classical, prehistoric and byzantine Archaeology by significant scholars such as Anastasios Orlandos, Spyridon Marinatos, and Georgios Mylonas and in byzantine, post-byzantine History, and the History of modern Greece by leading Greek scholars such as Dionysios Zakythinos and Nikolaos Vlachos. After an intermezzo in 1955, when he did his military service in Kalamata, he received his diploma in early 1957.

\section{Early Career (1956-1963)}

Petrakos' introduction to the archaeological fieldwork of Attica came in the summer of 1956 when he joined the Agia Triada excavations in Peiraieus directed by Ioannis Papadimitriou, ${ }^{2}$ at that time Director of Antiquities of Attica. Papadimitriou, who would become an important mentor for Petrakos, was since at least 1951 internationally famous (primarily through his discovery of Grave Circle B in Mycenae), but in the period of Petrakos involvement in Attica (1956) he was at the beginning of administering his great project for the excavation of the Artemis sanctuary in Brauron (19551963). During the subsequent period 1958-1963, in his leading position as Director of Antiquities and Restoration (1958-1963) Papadimitriou played a central role in the reorganization of the administration of the Greek Archaeological Service. ${ }^{3}$

From the beginning of 1957, Petrakos accompanied Papadimitriou every Saturday on his trips while getting acquainted with the problems of Attic topography. Between 1957 and 1959, Papadimitriou sent him to conduct works in the Amphiareion of Oropos on the occasion of the construction of an archaeological museum within the sanctuary. ${ }^{4}$ During these works Petrakos found in Skala Oropou, near the sea, pottery fragments of the Middle Helladic and the Early Mycenaean period, that offered for the first time archaeologically documented evidence for the existence of this formative period in the border area between Attica and Boeotia. ${ }^{5}$ Papadimitriou also assigned Petrakos with the task of preparing a catalogue of the inscriptions from Oropos stored in the Amphiareion, a work which he did in 1957 and which then formed the foundation for his $\mathrm{PhD}$ thesis completed eight years later in Lyon. ${ }^{6}$

$2193,67$.

$3233,163$.

4 76, 148.

$534,97$.

6 Compare nos 9 and 252. 
In December 1957, Petrakos, together with Olga Alexandri, cleaned out and produced for the first time a drawing of the temple of Artemis Tauropolos in Loutsa (Halai Araphenides), which had been identified by Nikolaos Kyparissis in the 1920s and was re-discovered by Papadimitriou in $1956 .^{7}$

In the next year (1958) Petrakos was employed by the Archaelogical Society at Athens together with Leandros Vranousis and Menelaos Tourtoglou to classify the archival material of the Society, a work completed under the supervision of Manousos Manousakas, a historian of medieval and early modern Greece. During this period, he read anything and everything related to the documentary holdings of the Archaeological Society's Archive. ${ }^{8}$ This laid the foundations of much of his later research in the history of Greek Archaeology.

The beginning of 1959 was for Petrakos an examination period, since he prepared

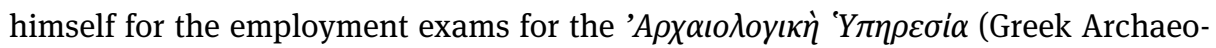
logical Service). In June 1959, he entered the Archaeological Service after passing the exams that had taken place in March 1959, ${ }^{9}$ for the first time since $1933 .{ }^{10}$ Five candidates were successful, which, in comparison to modern standards, is a very low number: Petrakos himself, Olga Alexandri, Manto Oikonomidou, Katerina Rhomiopoulou and Maria Karamanoli-Siganidou. ${ }^{11}$

Petrakos' first task as an Epimeletes (Curator) was to organize in summer 1959 the Museum in Delphi. He continued in the autumn of the same year with similar duties in the museum of Sparta under the directorship of the then Ephor of Laconia, Chrysanthos Christou.

In December 1959, he returned to Attica, where he begun his work in the ancient deme of Rhamnous. It was the 10th of December of 1959, when he visited the site for the first time as a young Epimeletes: that day proved to be a turning point not only in his life but also in the history of Greek archaeology. It was then that he began recording scattered and undocumented findings of previous archaeological investigations in the sanctuary of Nemesis under the supervision of Ioannis Kontis, by that time Ephoros of Antiquities in Attica, ${ }^{12}$ with the assistance of the sculptor Stelios Triantis. Retrospectively, the project "Rhamnous", which started some 60 years ago and ended this year (2020) with his monumental multi-volumed final publication entitled

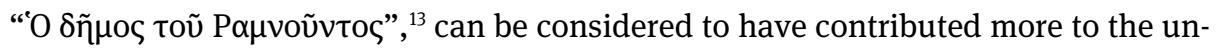
derstanding of an ancient deme's life in Attica than any other undertaking in the 20th

7 255, 32f.; Papadimitriou 1957, 46 fig. 2. On the temple and its finds, see now Kalogeropoulos 2013.

$8493,375$.

$9255,36$.

$10233,156$.

11 59, 102 (nos 99-103); 233, 130.

12 Ioannis D. Kontis was Ephor of Antiquities of Attica from November 1959 until October 1960 (see 233, 211 n. 117).

$13577 a-d$. 
century. His work fundamentally altered our picture of Attic demes and immeasurably increased our historical understanding, especially of Classical, Hellenistic and Roman Attica.

Already in 1960, while clearing away the 1890-1892 debris of Valerios Stais' excavations piled west and east of the Nemesis sanctuary, Petrakos was able to identify important, until then unnoticed, fragmented material such as column drums of the great temple, new relief fragments of the classical marble basis of the cult statue of Nemesis, as well as an important inscription connecting events of the Chremonidean War (267-261 BC), assigning them to specific buildings in Rhamnous. ${ }^{14}$ Until today (2020) and with the exception of a twelve-year period where he operated outside Attica (1963-1974), Petrakos devoted himself to the mission of exploring, preserving and publishing the monuments of Rhamnous and despite (or perhaps because of) his innumerous other interests and major publications related to many different aspects and topics of ancient Greek society, it is fair to say that he succeeded admirably.

The years after 1960 saw the rapid growth in the standards of living and of building activities in Greece and especially in Attica and in the islands of the Saronic Gulf, which as a consequence has been threatening to destroy huge amounts of material, documents of prehistoric and ancient Greek culture. Petrakos' salvage work in these areas during the period 1960-1963 was crucial. His rescue excavations recovered, documented and definitely protected large numbers of ancient monuments, that would otherwise have been lost due to building activities. Representative cases include the recovery of a portion of the Mycenaean chamber tomb cemetery at the hill of Kamini, which otherwise would have been destroyed by the extension of the SW suburb of Athens Varkiza, ${ }^{15}$ or the discovery in Kephissia of marble busts and body fragments belonging to Herodes Atticus and his pupils Polydeukion and Memnon, ${ }^{16}$ at a place where the Villa of Herodes must have been sited. ${ }^{17}$ Directly related to the scientific documentation and protection of the ancient monuments, but also to his (and later so characteristic of him) holistic approach to archaeology is the way he conducted restoration work during this period both in theory and in practice. Two cases may serve to exemplify this. First, there is his decision to write in November 1960 an architectural critique on the "barbaric" methods used by the architects of the Direction of Anastelosis (E. Stikas) to restore the Aphaia temple on Aegina, using extensively new materials. According to Petrakos the restoration "killed" the monument and it was certainly in contrast with what he has learned from Kontis about anastelosis-principles appropriate for temples. ${ }^{18}$ Although in his main point of criticism he

$141,37 \mathrm{f}$.

15 1, 40; on this Mycenaean cemetery, see Polychronakou-Sgouritsa 1988.

16 3, 30; 52, fig. 131 (Herodes Atticus), 132 (Polydeukion).

$1752,148$.

18 233, 152-154 n. 218; $158 f$. 
was certainly right, the fact that Petrakos was not an architect, i.e. not a "expert" in matters of anastelosis, in combination with the fact that in that period (November 1960) he was still very young, led to the result that his report failed to stimulate a scientific debate about the role of aesthetic matters in anastelosis. The second case was the difficult but scientifically successful stone by stone dismantling, transferring and re-erecting of one of the largest late classical funerary enclosures (periboloi) in Attica, that of Elliniko, near the Saronic Gulf, which would otherwise have been destroyed by the construction of the Runway of the Athens Airport (East). ${ }^{19}$

Petrakos' third archaeological point of focus in the period 1960-1963 was Eretria. While commissioned with the task to organize the exhibition of the new Eretria museum (constructed in 1959), he was able between 1961 and 1963 not only to clear the visible ancient structures of the site but also to reveal important new monuments such as the tholos, ${ }^{20}$ fragments from the pediment of the archaic temple of Apollon Daphnephoros, ${ }^{21}$ and an Ionic capital of votive character, ${ }^{22}$ and also to identify others (e.g. the Thesmophorion), ${ }^{23}$ as well as to publish for the first time useful architectural plans, among them an up-to-date topographical outline of the walled town. ${ }^{24}$ Furthermore, in the gully to the west of the site, i.e. in the area of the archaeological museum, he discovered in 1963 a great number of funerary inscriptions, which he published in two sets, ${ }^{25}$ testifying to the presence of a cemetery at this area. In addition to his fundamental field research, which had a strong impact in the subsequent fieldwork conducted in Eretria the last 55 years by the Swiss School of Archaeology, ${ }^{26}$ Petrakos published in this period some of his first epigraphical studies. The first piece was an inscribed base found in Eretria in December 1961. It concerns a dedicatory inscription on an honorary statue made by sculptor Teisikrates in the first half of the 3rd century BC for one Aeschylus Antandrides from Eretria, Hieromnemon in Delphi, known from other inscriptions and the literary tradition. ${ }^{27}$ The second one was an inscription on a square base which commemorates the erection of a Herm by a group of people named

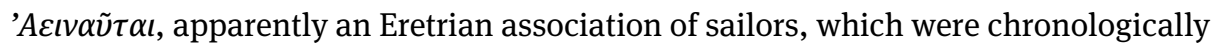
related to a board of three magistrates. ${ }^{28}$

\footnotetext{
$193,30-35$.

20 4, 148-151 fig. 6-7.

21 4, $144 \mathrm{f}$.

22 6, 127 fig. 7.

23 4, 145 fig. 2.

24 4, 153.

25 In 1968 (18), and in 1974 (34). On these funeral inscriptions, see the contribution of D. Knoepfler in this volume.

26 See the contribution of P. Ducrey in this volume.
}

27 2, 211-214 pl. 89-90.

287. 


\section{Epigraphical Studies in France (1963-1965)}

In July 1963, Petrakos moved with his wife to France for two years. Holding a scholarship of the French Government, he studied there Greek Epigraphy with Jean Pouilloux, Georges Roux and Henri Metzger in Lyon and with Louis Robert in Paris (Collège de France)..$^{29}$ Based on these seminars and lessons and on the catalogue of inscriptions he had compiled in 1957 in the Amphiareion, he wrote in the first months of 1965 his doctoral dissertation with the title Les inscriptions d'Oropos under the supervision of Jean Pouilloux in Lyon (Institut d'épigraphie Grecque - Institut Fernand Courby). ${ }^{30}$ Petrakos' dissertation contained partly the corpus of the inscription of Oropos but was partly also historical since it dealt with the history, the geography, the institutions and the prosopography of Oropos. ${ }^{31}$

\section{The Years as the Head of the Ephorates at Mytilini (Lesbos), Delphi and Patras (1965-1974)}

Returning from France back to Greece, he was appointed by Kontis as the head of the Ephorate of Antiquities of the Aegean Islands, succeeding in this position Serapheim Charitonides. Based in Mytilene on Lesbos, he was responsible for the islands Lesbos, Chios and Lemnos. During his stay there (summer 1965 until spring 1969) he was very active not only in digging sites in advance of development and in restoring, conserving and protecting important monuments, but also in publishing his earlier and current archaeological research.

The most important rescue and restorational work was done on Mytilene itself. First, he excavated the vaulted vomitoria and restored the famous Roman theatre of Mytilene. He offered the first accurate plan of the stage building and the orchestra of a monument, which according to Plutarch was to become the archetype of all Roman theatres, and provided drawings of the inscriptions and detailed descriptions of the older findings of Dimitrios Evangelides. ${ }^{32}$ Second, he conducted systematic restoration and conservation work in the Castle of Mytilene, which had been systematically looted during the crisis years of 1912 and $1922 .{ }^{33}$ Furthermore, he provided new and in comparison with those of Robert Koldeway and W.R. Paton - more accurate draw-

$29233,150$.

$309 ; 252,13$.

31 10, 45 n. 1 .

$3214,22,24$.

33 14, 460 pl. 337 y; 38. 
ings and plans of the main castle, the Middle, South and North Gates, the Great Enclosure, as well as plans and sections of the Gunpowder Magazine. ${ }^{34}$ Third, he recovered a large building with a high-quality mosaic floor, enclosing representations of winged Erotes, fauna and human portraits. ${ }^{35}$ The floor had been found in 1967 in the excavations during demolition of the old hospital in front of the church of Agios Therapon. In the modern deposits of this site he has also found a Roman inscription honouring Marcus Pompeius Theophanes described as cipovó $\mu \alpha{ }^{36}{ }^{36}$ Finally, Petrakos provided for the first time convincing evidence for the existence of a Jewish community on Lesbos during the $16^{\text {th }}$ century. ${ }^{37}$ In the area of the Post Trajan-Valaneion, he discovered and published a funerary inscription bearing the name of a certain Nadji Ispisansa di Alba, a Jewish rabbi or cantor, who seems to have reached Lesbos after the expulsion of the Jews from Spain and Portugal in the 15th or 16th centuries.

In addition to his work on Mytilene, he cleared in three campaigns (1966-68) the remains of the pseudo-dipteral Ionic temple at Mesa, in the middle of the island, excavated in 1885-86 by Koldeway. Within the covering soil of the temple, he found a hoard of 48 gold ducats of Andrea Dandolo (1343-1354). ${ }^{38}$ South of the surviving foundations, he uncovered stylobate blocks, bases, drums and parts of the stone sima. ${ }^{39}$

During his stay on Mytilene he was also able to publish several important works, two of which became sources of particular scholarly interest. The first one was pub-

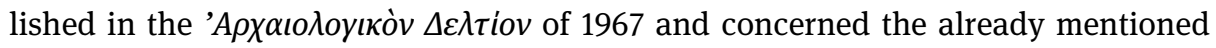
inscription found in Rhamnous in 1960, an important decree of the year 268/67 BC. The decree refers to activities of the Athenian general Epichares, who was elected

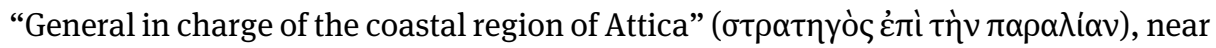
the coast of Rhamnous. According to this document, Epichares protected crops, vine-

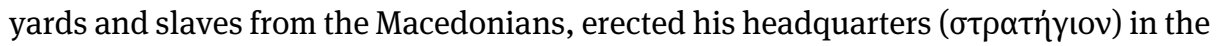
sanctuary of Nemesis (obviously to control among other places the whole plain of Limiko) and built shelters for the soldiers of the Ptolemaic general Patroklos, who was sent to help the Athenians against the Antigonids. ${ }^{40}$ Petrakos' 1967 -article broke new ground in that it testified, among other matters, that during the beginning of the Chremonidean War Rhamnous was under Athenian control. ${ }^{41}$

34 38, drawings $1-7$.

35 24, 368-370 pl. 378-381 (mosaics).

36 24, 370 no 1 (inscription).

3714,449 pl. $333 \alpha$.

$3815,98$.

$3915,100 \mathrm{pl} .80 \alpha$ (stylobate blocks), $80 \beta$ (sima); 19, 84 pl. $63 \beta$ (drums).

4013 ; 281b, 6-9 no. 3.

41 On the impact of this publication on our understanding of the Chremonidean War, see Oetjen 2014, 12f. notes 18-22 (lit.). 
The second work was one of his most prominent studies - the well-known monograph about Oropos and the monuments of the oracular healing sanctuary of Amphiaraos, which was published in $1968 .{ }^{42}$ It contained the history of ancient Oropos and an analytical description of the Late Classical, Hellenistic and Roman monuments of the sanctuary of Amphiaraos, whose cult was introduced at this border site during the Peloponnesian War, apparently from a place called Knopia near Thebes, where it was originally established. ${ }^{43}$ Based (a) on the results of the largely unpublished excavations of the Archaeological Society in the Aphiareion conducted between 1884 and 1930 under the directorship of Spyridon Phintiklis and Vasileios Leonardos ${ }^{44}$ and with the collaboration of Wilhelm Dörpfeld ${ }^{45}$ in the first campaigns, (b) on new research which he conducted on the monuments (inscriptions included) and (c) on the study of the relevant literary tradition, Petrakos offered a systematic monograph which completely replaced Félix Dürrbach's 1890 dissertation on the subject. ${ }^{46}$ In this monograph Petrakos demonstrated, with his characteristic clarity and precision not only his perception of the inscriptions as "monuments who carry inscriptions" (and not just as "inscriptional writings"), ${ }^{47}$ but also his particular ability to combine meaningfully the skills of an archaeologist with those of a philologist in elucidating the historical significance of the monuments under study.

Besides archaeology, the service years on Lesbos were in general very exciting and productive ones for Petrakos. This is well documented in many articles of his later periods. Mytilene was at this time still one of the most active cultural and social centres in Greece. These were the years with the intense relationship with several writers and artists who influenced him such as Asimakis Panselinos, Stratis and Miltis Paraskevaidis and Takis Eleftheriadis. ${ }^{48}$

While serving on Lesbos, but also later in Delphi, he participated in the Local Commissions on Toponyms of the Greek Ministry of Interior. From his writings one appreciates that he was not always willing to accept the decision of the Commissions

42 16. Among the new material observed by him is also an important archaic votive capital found in Sykamino(s) ca $2 \mathrm{~km}$ west of Oropos incorporated in the Agia Eleousa church (16, $16 \mathrm{n}$. 5). On this find, see now M. Korres in this volume.

$4316,66 f$.

44 On V. Leonardos s. 573.

45 On W. Dörpfeld's relations to the Archaeological Society at Athens s. 112.

46 Dürrbach 1890.

47 See for example 16, 145 fig. 35, which shows a plan of the bases of the sanctuary indicating with shadowing the readable, inscribed sides of the monuments. On this methodological approach in the case of the inscriptions, see Raubitschek 1964.

48 356, 81f. 
especially in the cases when these Commissions tried to change place names seemlingly not Greek but in reality, either common in the Byzantine heroic poetry ${ }^{49}$ or indeed ancient Greek. ${ }^{50}$

In Spring 1969, he was moved to Delphi, where he continued his work on the protection and publication of Greek antiquities. Due to his efforts the wider archaeological site of Delphi (including Desfina, Arachova and Itea to the south) was declared as a "protected area". ${ }^{51}$ As a result of this declaration the abuse of the area by man was severely curtailed. He also conducted important excavations and cleanings, including those on the sanctuary of Demeter and Kore at Souvala/Polydroso (ancient Erochos) in northern Phocis (formerly excavated by Christos Karouzos), where he found a great amount of pottery and small finds (figurines) ranging from the Archaic to the Hellenistic periods, ${ }^{52}$ and also those in the coastal site of Kirrha, where he recovered Middle Helladic graves and part of a Late Mycenaean settlement..$^{53}$ During his stay in Delphi he also published two monographs: the Delphi Guide for visitors (1971) ${ }^{54}$ and

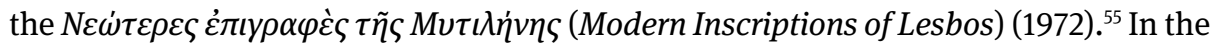
second study, he published important inscriptions from Lesbos of the 18th and 19th centuries found on churches, bridges, fountains and houses. By doing so he included in the publication not only the text of the inscriptions but also drawings of the architectural monuments in which they were incorporated, as well its decoration.

Between 1973 and 1974 he was based in Patras, where he operated as Ephor of Antiquities and simultaneously as Inspector of Culture and Science in the Peloponnese and Western Central Greece. During this time, he published important works such as his study on the Mycenaean Oropia ${ }^{56}$ and the first edition of his Guide on the Amphiareion of Oropos (1974)..$^{57}$

$49194,72$.

50 Such was, as Petrakos explains, the place name "Chriso" in Phokis (an altered form for ancient "Krisa") which was falsely transformed with "y" as "Chryso". Decades later, in 1993, another state Council on Toponyms was of the opinion, contrary to the historical truth, that the modern place name "Mesa" should be replaced as not signifying anything in particular, but Petrakos was able to demonstrate that it was a survival of the epigraphically-attested ancient place name "Messon", on Lesbos, a temple site where he himself had excavated in 1967 (194, 72f.).

51 Iakovidis 2000, 557.

5228.

5331.

5427.

5529.

5634.

5736. 


\section{The Years as Ephor of the Sculpture Collection in the National Archaeological Museum (1974-1976) and Ephor of Attica (1976-1994)}

In 1974, Petrakos returned to Attica, to take up the position of Ephor of the Sculpture Collection in the National Archaeological Museum in Athens. Two years later, in 1976, he became Ephor of Attica and held that post until 1994.

During his Attica-Ephorate (1976-1994), besides supervising numerous "rescue" excavations he took concrete actions to preserve the heritage of Attica's past as well as Attica's natural and historical landscape and to protect both (monuments and surrounding area) from destruction. These efforts included fighting against illegal digging and exporting of antiquities, attempts to control international exhibitions, actions to ensure that large areas surrounding ancient relics had been designated as archaeological sites (e.g. the relevant designation of the entire valley of Limiko, to the south of Rhamnous in 1977) or legal initiatives that led to the stopping of the construction of mines promoted by governments (as for example in the case of the marble quarries of Rhamnous in the period 1993-1995). ${ }^{58}$ However, as in his early years of service in Attica (1957-1963) both with the case of the above mentioned non-scientific restoration of the Aphaia temple on Aegina and in that of the "barbaric" use of the ancient theatre of Piraeus by Dora Stratou, ${ }^{59}$ (in which disagreement, he was strongly reproached by his supervisor I. Papadimitriou) ${ }^{60}$ so too in his mature years: his opposition to actions, which he rightly considered harmful for the monuments, in many instances was unable to turn the opinion of the official state and most of his colleages in favour of the antiquities, as was the case with his attempts to cancel the construction of the new Aegina-Museum at the archaeological site of Kolonna in $1977^{61}$ or to prevent the conversion of the island of Psyttaleia near Salamis into a reservoir of sewage for the Athens basin in $1985 .^{62}$

His scientific interests retained a specific geographical focus: the region of northeast Attica and especially the sites of Oropos, Marathon and especially Rhamnous.

As regards Oropos: first, based on fresh examinations of the Oropian stones, which he undertook after 1976, he proposed new readings, descriptions and interpretations of the inscriptions of this border city. As a result, he published in 1980 a valu-

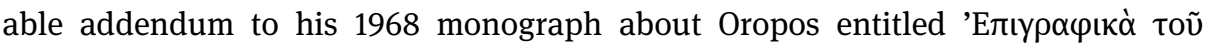

58 418, 154; 493, 581 n. 39.

$59271,71$.

60 239, 106.

$6192,20$.

$62369,33$. 
' $\rho \omega \pi о \tilde{.}{ }^{63}$ It contained chiefly inscriptions from the ancient site near the sea (modern Skala Oropou), related especially to the cult of Halia Nymphe, in honour of whom games were celebrated in the 3rd cent. B.C.

Second, in 1997 he published in a monumental monograph the definite publication of "The Inscriptions of Oropos", ${ }^{44}$ which contained some 770 epigraphical texts from the 4th century to the Roman imperial times, among them proxeny decrees, inscriptions concerning the sanctuaries and the city, as well as dedications. It constitutes the complete corpus of Oropos inscriptions, which reveals the political, religious and to a degree the daily life of a city located on the borders of Attica. In the words of Michael H. Jameson ${ }^{65}$ a "masterful publication", with "excellent drawings" which made "it possible to understand the nature of each monument", a publication which set new standards in the study and publication of Greek inscriptions. ${ }^{66}$

As far as Marathon is concerned, he published in 1995 a very useful Guide on the topography, mythology and the finds stored in the Archaeological Museum of Marathon from prehistoric to Roman times with a special emphasis on the contribution of all the above data to understanding aspects of the battle of Marathon. ${ }^{67}$

\section{Excavations and Studies in Rhamnous (1975-2001)}

His greatest contribution to the academic discipline came, however, in his work at Rhamnous. As already stated, Petrakos' involvement in the exploration and study of Rhamnous began in December 1959, where under the supervision of Kontis he initiated long-term works in the sanctuary of Nemesis. In 1975, he was able to resume excavations in Rhamnous and to continue hereby the pioneering work of John Peter Gandy Deering (1813-1814), Dimitrios Philios (1880), Valerios Stais (1890-1892), Jean Pouilloux (1954) and Efthymios Mastrokostas (1958).

For 27 consecutive years (from 1975 to 2001) he dedicated his life to excavating systematically this Attic deme on behalf of the Archaeological Society at Athens in the quest first to dispel the scientific confusions caused by the early excavators (especially those by Stais, which were due to the lack of systematic research methods and proper documentation of his findings) ${ }^{68}$ and second to reveal its many hidden

6348.

64252.

65 Jameson 1999, 323.

66 So Doukellis 1998.

67230.

6844 , 1f. 
secrets in order to reconstruct the real picture of the ancient deme. ${ }^{69}$ During this period, he brought to light impressive evidence for monumental sacred, funerary and defensive architecture, hundreds of new inscriptions, marble sculpture and reliefs, coins, pottery, lamps, and several other finds from different materials far beyond anyone's expectations, in the words of Christian Habicht, “... with such success that one could perhaps say that over the last 20 years no other place on Greece ... has yielded as much as Rhamnous". ${ }^{70}$

The research design applied by Petrakos in Rhamnous was sound and exemplary. He not only was the first in Rhamnous to open broad-based excavation areas (horizontal stratigraphy) rather than to randomly dig holes to unearth spectacular sculptures or inscriptions as earlier excavators at the site have done, but he always began with the thankless task of re-excavating finds already revealed either by earlier excavators or by looters. Whenever possible, any previous excavation was also studied along with relevevant field note diaries (e.g. the relevant pages of the 1813-diary of J. P. Deering, now in the British Museum) ${ }^{71}$ maps, historical documents, drawings and photographs. His intention was always to clarify and whenever possible to solve old scientific problems before proceeding to the new ones.

Directly related to the effectiveness and successful completion of his research planning was his talent to assign within his overall research plan the right person to the right position. As far as the archaeological fieldwork was concerned, he persisted for example in digging and working with a small but very competent and dedicated staff, including the archaeologist Eleni Theocharaki who oversaw the whole excavation project until her death in 1995, the very skillful Ioannis Karamitros, ${ }^{72}$ known from his work at Mycenae and Marathon, as excavation forman, the excellent Tenian marble worker Nikos Karamalis and his son Giorgos, both with a keen eye in every matter concerning the marble monuments. As far as the final stage of the excavation process is concerned, for the final publication he hired artists for the documentation of his finds, including the painter Kostas Iliakis for the drawings of the excavated monuments, the talented conservator and artist Tasoula Voutsina for preserving the excavated artifacts and the painter Manolia Skouloudi for the drawings of the objects. ${ }^{73}$ As a result he kept during all the 27 years of the excavation meticulous records of his excavations (plans, photographs and drawings of monuments and thousands of artifacts). In a later stage, he begun to bring also scientific experts to study the human

$6999,10$.

70 Habicht 1998, 388.

71 44, 46-55.

72360 .

7344. 
skeletal remains found in the site,$^{74}$ the pottery and the small finds from the Thesmophorion $^{75}$ and to conduct geophysical surveys in order to define the form of the two harbours of Rhamnous. ${ }^{76}$

Some results of this research principle are mentioned below, selectively using cases relating to all three constitutional parts of the deme: the Nemesis-sanctuary, the funerary periboloi and the fort.

The Nemesis Sanctuary: By clearing the debris of the old excavations of Stais in the sanctuary of Nemesis, Petrakos recovered hundreds of fragments of the base of the cult statue of Agoracritus' Nemesis, to which other fragments already found by him in the National Archaeological Museum have been attached. This led to the restudy and reconstruction of the base, three faces of which carried relief sculptures known from Pausanias' description (1.33.8) as showing the story of Helen brought by her mother Nemesis to be reared by Leda. ${ }^{77}$ Through Petrakos' new reconstruction it became clear that Pausanias' description of the base is inaccurate since it refered to fewer (12) human figures than actually existed (14 or 15 as well as two horses). He also showed that reconstructions previously proposed for the form of the base were also misleading, since the base was in reality constructed of two Pentelic marble blocks and the crowning element was of black Eleusinian marble.

In the same debris, he recovered also a great number of architectural elements which have been identified as belonging to the classical Temple of Nemesis, ${ }^{78}$ the latest of a series of four temples which were erected in the sanctuary of the Goddess. These identifications enabled the restoration of the entablature of the classical temple ${ }^{79}$ a process which began in August 1980 within a building constructed by him in 1979 for this very purpose. The building which also included under its roof the reconstructed base of the cult statue of Nemesis, ${ }^{80}$ has continued until our days to protect the monuments but at the same time it operates as a site-museum for study purposes.

Furthermore, it was especially pleasant to him to confirm through these recoveries an earlier opinion expressed about a puzzled dedicatory epigram by Jean Pouilloux, his teacher in Lyon. It concerns the epigram IG II ${ }^{2} 3105$, which has been also known since Stais' campaign of 1891. Through the addition of two new marble fragments Petrakos was able to certify that this epigram was in fact an Ephebic document dated to 332/1 BC, as Pouilloux had suggested years before. ${ }^{81}$

74 577c, 348 (investigation of grave 8 in the north-east cemetery conducted in 2000 by Anna Lagia).

75 Nawracala 2014.

76 577a, 328 (conducted between 2003 and 2011 by David Blackman and his team).

7768 ; 281a, 251-266.

78 577b, 273-311.

79 118, fig. 20.

80 118, fig. 19.

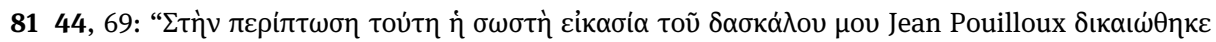

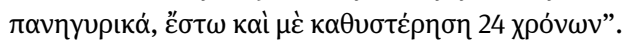


Petrakos' meticulous examination of the finds as well as his holistic approach to the publication of the results of the older and his own excavations in the Nemesis sanctuary stands as a model for a sanctuary excavation and publication. His final publication includes not only the reconstruction of the base of the Nemesis statue and catalogues accompanied with numerous photos and line drawings of the architectural fragments of the classical temple and its three predecessors, but also thorough catalogues of all the - mostly votive - objects found in the sanctuary terrace fill and in the fill within the ill-started shaft of the north spring-house. As a result, the "Nemesion" of Rhamnous ${ }^{82}$ can be regarded as one of the most throroughly investigated sanctuaries in Attica, especially for the period between the second quarter of the 6th until the mid 5th centuries BC.

The Funerary Periboloi. On the sacred way to the south and north of the Nemesis sanctuary several funerary periboloi (family graves), excavated between 1890 and 1892 by Stais and which had been left scattered in the field, undocumented and unprotected, have been studied by Petrakos and some new restorations of their appearance have been proposed. These include the family graves and their associated grave stelae, grave reliefs and marble funeral vases (loutrophoroi, lekythoi) - originally displayed above the front wall of the periboloi for public viewing - of important Rhamnousians of the 4th century BC such as Menestides and Euphranor (whose inscription reveals that he was 105 at his death) to the south sacred way or Diogeiton, Phanokrates, Pytharchos to the northern and most importantly the remarkable funerary peribolos of the conspicuous family of Hierokles. ${ }^{83}$

The Fort. Already in 1977 but especially after the beginning of the 1990s Petrakos turned his attention to the coastal acropolis with the classical fort. Through his excavation method (clearing the full horizontal extent of the acropolis) he revealed great parts of the settlement within the fort basically in its latest phase, that is of the Roman period. But he also revealed older material dating back from the Early Neolithic to the Early Bronze Age, and especially from the Archaic and Classical through the Hellenistic periods. This older material came to light either after digging test pits, because of its secondary use (e.g. the re-use of the flat and durable inscriptions as building material in the houses) or as a result of secondary processes (redepositions, mixed strata). A characteristic example of the first case is a votive deposit especially of blackfigured kylikes, skyphoi and kraters dating from c. 565 to 475 BC which he found within the so called Gymnasion. These votive vases had been deposited there presumably after they had lost their primary function. The deposit, which has been con-

$82577 b$.

83 On the funerary peribolos of Hierokles s. 41, 49, 281a, 387-399. On the periboloi of Rhamnous s. 281a, 340-413; 577c, 207-256. 
nected by him with a Dionysos-sanctuary, stood initially in a prominent area, presumably in the area of the Agora. ${ }^{84} \mathrm{~A}$ typical example of the second case are, as stated above, the inscriptions. By documenting always their physical support and find place, Petrakos was able to publish (or to republish with enhanced and expanded versions of old readings) a total of c. 980 inscriptions from the site which constitutes the greatest number of inscriptions among the Attic demes. These inscriptions were dated mainly to the Hellenistic period and include decrees mostly of the Athenian garrison stationed in Rhamnous (often together with the demotai of Rhamnous) honouring Generals by describing their duties, ${ }^{85}$ dedicatory ${ }^{86}$ and funerary ${ }^{87}$ inscriptions and graffiti ${ }^{88}$ and other written documents reflecting the daily life within and outside the fortress. His meticulous studies led also to corrections in the reference corpus of the Inscriptiones Graecae. As in the case of the marble fragments deriving from the fill of the Nemesis-sanctuary, where Petrakos revealed that several inscriptions which were until then published as being decrees of the demos of Sounion, e.g. the lease of land at Herme IG II 2493 (339/8 BC) ${ }^{89}$ or the "deme decree" II $^{2} 1181$ from Sounion" were not from Sounion but in fact belonged to Rhamnous. It turned out that the confusion was due to the fact that in the turn of the 20th century, when Stais transported some inscriptions which he found in Rhamnous to the National Archaeological Museum along with inscriptions from Sounion. Many of these inscriptions are of great historical interest (for example the already mentioned decree honouring General Epichares for services during the Chremonidean War). Others are of special chronological value since they supplied important contributions to a better understanding of the Athenian calendar (e.g. the honorific decree for General Archandros, which helped to specify the chronology of the Diomedon's archonship in the year 248/7 BC. $\left.{ }^{91}\right)$. Others, in turn, document important religious practices such as the decision of the demos of Rhamnous to make an annual sacrifice to king Antigonos Gonatas (form of deification) $)^{92}$ or the existence in Rhamnous of a specific group of youths, named "критто'", ${ }^{93}$ which have been described as being different from the normal citizen

84 577a, 226-271 figs 94-125. See M. Tiverios in this volume.

85 99, 10; 281b, 5-63 nos 1-61; 577d, 13-15 no 401, 18-60 nos 403-445.

86 281b, 71-131 nos 74-166; 577d, 61-101 nos 446-505.

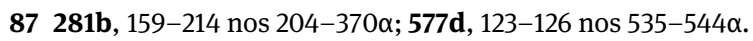

88 281b, 215-221 nos 371-400; 577d, 127-154 nos 545-807ๆ.

89 281b, 143-146 no. 180.

90 The deme degree $\mathrm{II}^{2} 1181$ from Sounion was in fact a base found in Rhamnous with the inscription showing that it belongs to the ephebes of Aiyni (281b, 85f. no 99).

91 Oliver 2002, 7.

92 281b, 11-13 no. 7.

93 281b, 8-9 no. 3, 26-28 no. 20. 
soldiers (stratiotai). The word indicates a special relationship with the Spartan kryptoi, the age group which underwent the Greek rites of passage, where young people were subjected to trials before being incorporated in the community. ${ }^{94}$

Petrakos' ability to appreciate quickly the significance of his findings, combined with the careful and swift documentation of his excavations resulted in regular, detailed and comprehensive preliminary reports published uninterruptedly for 27 years

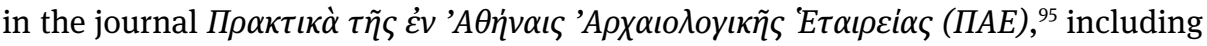
also an important report of the campaign of 1978 with a summary of his first five years

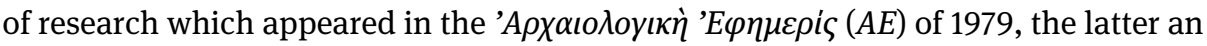
example of Petrakos' method and erudition. ${ }^{96}$ The final results of these excavations

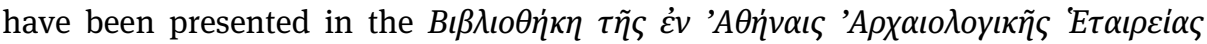
$(B A E)$, the publications series of the Archaeological Society at Athens. There are six

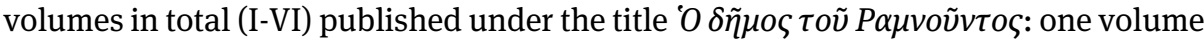
on topography (I), two on epigraphy, graffiti, weights and written evidence (I, VI), one on the fortress (III), one on the Nemeseion (IV) and one on coins, lamps and sculpture (V). ${ }^{97}$

\section{Secretary General of the Archaeological Society at Athens (1988-Present)}

While still serving as Ephor of Attica, in June 1988, at the age of 56, distinguished for his passionate determination in protecting and publishing Greek antiquities and for being one of the most brilliant and prolific members of the Archaeological Service in Greece (both as Epimeletes and as Ephor), Petrakos was elected as the 11th Secretary General of the Archaeological Society at Athens, replacing in this position the prominent Aegean archaeologist Georgios Mylonas. It was the first time that a state archaeologist - and not a university-based archaeologist, philologist or architect - was elected to this position.

Founded in 1837 with the aim to support scientifically the young Greek Archaeological Service in its tasks of the protection, study and presentation of Greek antiquities, the Archaeological Society played - besides the splendid results of its field activities at important archaeological sites such as Akrotiri on Thera, Mycenae, Zakros, Vergina, Epidaurus, Messene, Dodona, Eleusis or Brauron, to name only some typical

94 Ma 2008, 194.

$9537,39,41,43,45,50,53,60,62,65,67,69,71,77,87,103,117,154,181,214,229,242,251,267$, 280, 293, 304.

9644.

97 281a-b; 577a-d. 
examples - a crucial role also in the construction of the identity and national unity of the modern Greek nation-state. Following Mylonas' death in April 1988, however, the Society had fallen into a crisis - seemingly of financial, but in reality of a deep-rooted existential nature. For decades the institution had been slowly declining towards something akin to fossilization. Consequently, Petrakos was faced with a number of problems, ${ }^{98}$ caused not only by the mismanagement of grant funds, but also by the non-publication of the archaeological fieldwork sponsored by the Archaeological Society by those archaeologists responsible for it. As a solution he proposed a set of significant and innovative measures. ${ }^{99}$ In the next decades, Petrakos committed himself with all his energy, initiative as well as his organizational and administrative skills, to the materialization of these measures. These constituted a break with the past. In retrospect, it is fair to say that under his leadership the Society not only survived the critical years of 1987-1988, but actually entered into a period of rapid academic development and social responsibility. This finally led to the transformation of the Archaeological Society from a basically funding mechanism for archaeological excavations to a real research-oriented institution, ${ }^{100}$ generating also innovative ways to engage broader parts of the scientific community, especially younger people, in this research.

The most important measures taken by Petrakos in order to master these problems can be summarized as follows:

(a) Excavating less and instead investing in long-unpublished material brought to light by excavations sponsored by the Archaeological Society.

In order to overcome the widespread failure to publish in a timely manner the enormous quantity of the material from excavations of the Society, material long residing in repositories and slowly being forgotten over the course of time, he decided first to limit the number of new excavations carried out by the Archaeological Society and second to initiate an editorial project aiming to increase final publications of excavations in which the Society was directly involved. ${ }^{101}$ At the same time he encouraged the study of material housed in museum-magazines and warehouses. ${ }^{102}$ This project eventually proved to be a pragmatic solution, since he managed to push up the number of publications in the series of the Archaeological Society $(B \iota \beta \lambda \iota \theta \dot{\eta} \kappa \eta \tau \tilde{\eta} \varsigma$

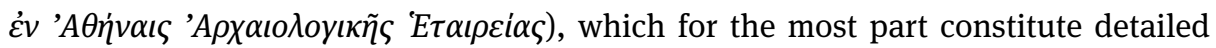

\footnotetext{
$98493,568$.
}

99 127, 1f.

100 In a declaration of intent already published by Petrakos in 1987 in the Ideography of the Archaeological Society $(\mathbf{7 2}, 181)$ he speaks of "a scientific centre of Greek archaeology”.

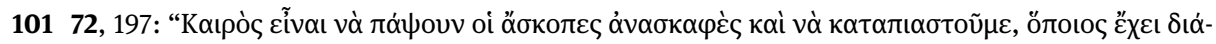

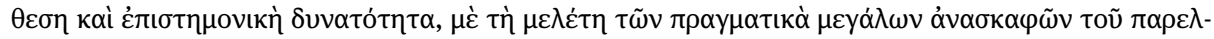

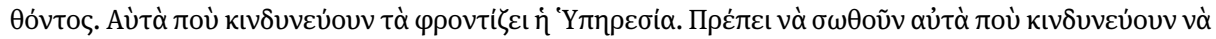
$\lambda \eta \sigma \mu о v \eta \theta 0 \tilde{v}{ }^{\prime}$.

102 493, 565-569. 
publications of the results of the Society's excavations, to an unprecented record: he rapidly tripled the number of the volumes published in the first 150 years of the Society's existence from 106 in 1988 to 327 in 2020. With this strategy of publishing the results of old excavations, he gave at the same time the opportunity to younger archaeologists (including the present writer) to analyze and to publish material from old excavations.

(b) He developed an effective archival infrastructure and a proper archival policy in order to ensure the preservation and dissemination of the archives of the Archaeological Society for present and future generations of researchers.

Until 1988, various categories of the valuable archive of the Archaeological Society at Athens (papers, photographs, drawings, diaries) were deposited in the basements of its main building, on Panepistimiou Str. 22, widly scattered, the majority of them unclassified and inactive. Based on personal knowledge he had gained from his involvement 30 years earlier (1958) in the organization of the archive of personal papers and manuscripts (copies of the Secretary's letters, archives of several archaeologists, original correspondence, secreterail papers) and already fully aware firstly of the fact that the Archaeological Society had a considerable amount of archived material from the 19th and 20th centuries and secondly that such material comprised a valuable research resource for the study of Greek archaeology, he proceeded to a systematic classification and conservation of the entire collection of original information records concerning Greek antiquities in order to facilitate access and usage of the documents by a variety of researchers.

This collection, which is a result of generations of archaeologists leaving personal and fieldwork-related material to the Archaeological Society because of its place at the foreground of archaeological research, comprised until 1988 three main categories: (1) personal archives of archaeologists (excavation diaries included), (2) photographic material and (3) drawings.

(1) Examples of personal archives of archaeologists from 1837 onwards included (a) the important archive-diary of Panagiotis Efstratiadis, who acted as General Ephoros of Antiquities from 1863 to 1884; (b) papers and manuscripts related to Panagiotis Stamatakis and his work in Mycenae, especially letters of Stamatakis to the Archaeological Society containing reports of his activities with descriptions of the antiquities he found and the places he saw; (c) the extensive archives of earlier Secretary Generals of the Archaeological Society such as those of Stephanos Ath. Koumanoudis (Secretary General from 1859 to 1894) or Georgios Oikonomos (Secretary General from 1924 to 1951), to name but a few.

Realizing that the Archaeological Society was well placed to develop historiographical research because of the depth and breadth of its archival holdings, Petrakos actively requested the deposit and donation of archival materials of members of the Archaeological Society and of other archaeologists of the Archaeological Service who posess archival material related to Greek archaeology. By incorporating after 1988 new and important archives of archaeologists into the Society's archive collections 
he made the Archaeological Society an important central archival authority. Among these newly bequested archives, which were acquired solely due to his own actions, belong the valuable archive of drawings, scientific notes and photographs of the architect and architectural historian Ioannis Travlos, donated to the Society by its family in $1993,{ }^{103}$ the archive of Ioannis Papadimitriou, donated by his son in 1994, a large part of the archive of Christos Karouzos, ${ }^{104}$ the archive of Dimitrios Pallas and a great part of the archival holdings of Apostolos Arvanitopoulos, including many diaries concerning the Society's excavations in Thessaly, donated to the Society by the Second Ephoreia.

(2) The second category of the collection comprises the photographic archive, which includes both negatives and positive images. The photographic archive, totally unknown before 1988, after the 1990s received constant requests to supply data related to the Greek monuments and the excavations of the Archaeological society. Tens of thousands of photos were for the first time available to researchers.

(3) The same holds true for the drawings archive, which was also organized for the first time: thousands of original drawings (architectural plans, object drawings, maps) and artwork (paintings of Émile Gilliéron fils and Alekos Kontopoulos) have been conserved and made available to researchers.

Furthermore, he increased public access to these archives. This has been achieved on the one hand through utilising modern technology (all the archival collections have been digitized and large portions of these became available via webbased links) and on the other through exhibitions performed within the central building of the Archaeological Society. Examples of the latter include the 1990 exhibition displaying photographs and drawings from the excavations of Wilhelm Dörpfeld ${ }^{105}$ and the 2005 exhibition entitled "Peloponnesos 1910, photographic documents" displaying photographs taken in 1910 by the Royal Prussian Photogrammetry Institution under the direction of the German architectural historian Theodor von Lüpke, which had been sent to the Archaeological Exhibition held in Rome in 1911. ${ }^{106}$

In the context of the dissemination of archaeological data in wider cicles it should also be noted that he provided users of the library of the Archaeological Society, one of the best archaeological libraries in Greece, with an on-line catalogue with advanced search options and enhanced content, such as summaries/abstracts and tables of contents in each item.

(c) He initiated an entirely new research area: Research programs related to the ancient monuments and cults of Athens and Attica. Besides the many research pro- 
grams which he, as Secretary General, promoted, either sponsoring them, as the Lexicon of Greek Personal Names (LGPN) project, or hosting them in the central building of the Society, such as the Greek department of Lexicon Iconographicum Mythologiae Classicae (LIMC), he initiated and developed under his direction three research programs related to the study of ancient Athens and Attica. The first one, the Archive of the Monuments of Athens and Attica (APMA), is a corpus of data comprising every possible source of information related to antiquities (e.g. from hard to find Greek journals of the 19th century such as Philistor, Athenaion, Ora, Ephemeris ton Philomathon) excavated or found in Athens and Attica in the last two centuries. The study is especially important for the 19th century, when regular publication of the excavations conducted in modern sense did not exist. The data were classified on the basis of topographic position and monument category, synthetically presented in order to gain a more complete picture of ancient Athens. In the second one, the Corpus of Attic Funerary Monuments ( $E$ EMA), he applied his solid method of examining not only the inscriptions as writings but also the archaeological aspect of the monuments, their physical support. ${ }^{107}$ The third project, which is still active, is a very useful collection of testimonia on the ancient cults of Athens and Attica. All of these projects have been conducted at the central building of the Archaeological Society by a team of experts in Greek epigraphy. ${ }^{108}$

(d) He initiated the School of Teaching the History of Art. In compliance with one of the initial aims of the Archaeological Society, he promoted the dissemination of knowledge in wider cicles of the Greek society regarding the history of ancient (Greek and Roman) and modern civilization (art and literature) by initiating the School of Teaching the History of Art. ${ }^{109}$ The latter owes much, especially after 2003, to the energy and organizing talent of his most trusted advisor and co-editor of this present volume, Dora Vassilikou.

(e) With articles in journals, especially in the newly founded Mentor and with substantial and significant public speeches at the Archaeological Society at Athens (fig. 2), he attempted to create an interest in the fate of Greek antiquities - especially among the modern Greeks - and to persuade public opinion that a revision of current attitudes and policies towards antiquities was necessary to avoid further destruction.

$107184,4$.

108 The results of these research projects have been published by the epigraphists Georgios Papadopoulos, Voula Bardani and Georgia Malouchou and by the archaeologist Ourania Vizyinou as separate monographs in the publication series of the Archaeological Society (APMA: BAE 127, 136, 177, 247, 265, 304; $\Sigma$ EMA: BAE 241).

$10972,181$. 


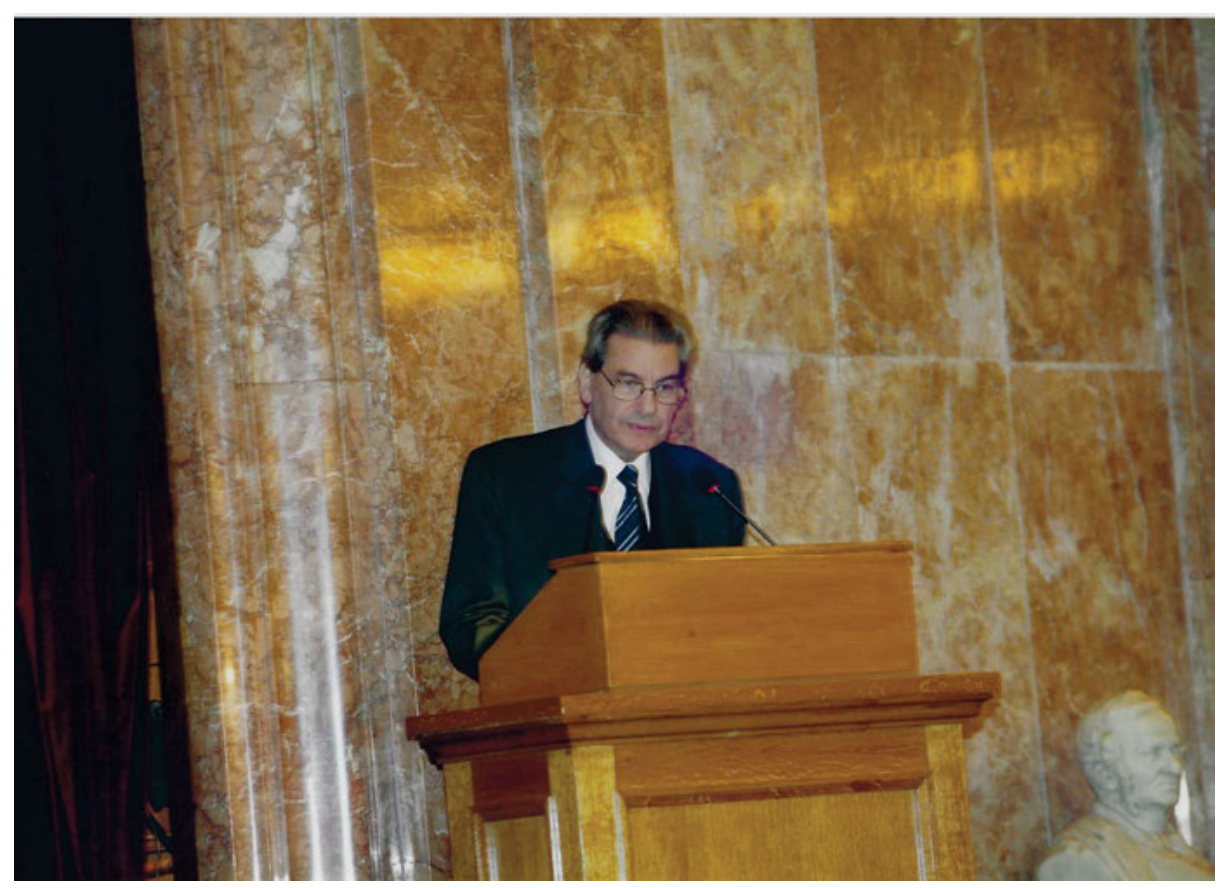

Fig. 2: Vasileios Petrakos, while lecturing in the Great Hall of the Archaeological Society at Athens. To the right is the bust of Alexandros Rizos Rangavis, first Secretary General of the Archaeological Society. Photo 2006: Courtesy of D. Vassilikou.

Besides becoming the general editor of the three already mentioned main periodicals

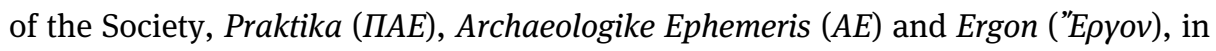
1988 he launched a new one featuring contributions primarily about the history of

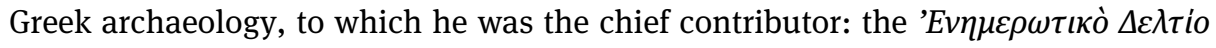

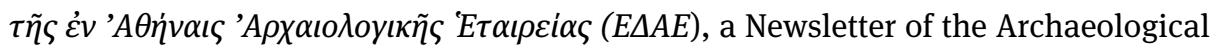
Society, which after 1992 was called $\dot{o}$ Mév $\tau \omega \rho$ (Mentor). In many of his Mentor articles and in the introductory speeches in the Ergon each May, Petrakos presented himself as an outspoken and often aggressive critic of acts, contemporary tendencies and attitudes he considered harmful for the Greek antiquities. These include not only acts with obvious irreversible harms such as looting, smuggling and desecrating antiquities but also others such as the opportunictic modern use of archaeological sites and ancient monuments (e.g. ancient theatres) for personal and commercial gain ${ }^{110}$ or the borrowing of antiquities for travelling exhibitions. The latter had been considered by him also as a harmful act since, ultimately, even a temporary display of an arti-

$110241,126$. 
fact can lead to the desire to acquire such a piece for a permanent collection, promoting in this way its cultural and economic value and, consequently, the illegal antiquities trade. As Secretary General of the Archaeological Society as well as a former Ephor of Attica, he succeeded in 2002 through his efforts in raising international awareness and in turning much of the scholarly opinion against building activities on the Marathon plain for the Olympics in 2004, the site being of great historical importance, since it was there that the Athenians and Plataeans defeated the Persians in 490 BC. But, as the construction of the Olympic Rowing and Canoeing Centre in Schinias finally showed, unfortunately, he had little success in changing the thinking of the official state and of most of his colleages.

\section{Studies in the History of Greek Archaeology}

\section{Definition of Subject and Method}

In addition to his archaeological and epigraphical work Petrakos developed in the early 1980s a strong interest on the historiography and history of Greek archaeology, which has been intensified in the following decades. The term "History of Greek archaeology" is typically understood either as the history of the development of the Greek branch of classical archaeology as an academic discipline (Bronze Age archaeology usually included, at least in name) or more generally still as a history of the exploration of the Greek world, sometimes even as a pure narrative of spectacular finds which have been through the ages brought to light in Greece. Petrakos concentrates on features of different sort. "History of Greek Archaeology" is for him the history of protecting, uncovering and publishing Greek antiquities. To Petrakos historiography of Greek archaeology is basically a history of the institutionalized, professionalized or "scientific" Archaeology in Greece, which begins conventionally on 21 October 1829 with the foundation of the National Museum of Aegina by Ioannis Kapodistrias under the directorship of Andreas Moustoxydis ${ }^{111}$ and comprises roughly the past 200 years.

Obviously, the best way to look at this issue is through surveying the development of the three main Greek institutions devoted to the above topic: The Archaeolog-

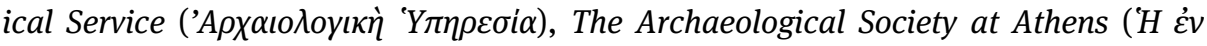

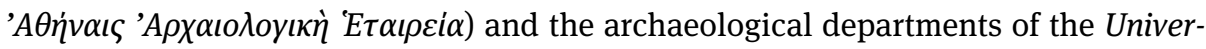
sity. Having a close and long-standing connection with the first two Greek institutions Petrakos focused, naturally, on a survey of their development rather than that of the University. Over the last 40 years (1981 to present) he wrote voluminously on them,

$111233,16$. 
while in the same time, by revealing the ideology and the contributions of the persons involved with them, he recognized and emphasized the importance - especially - of the internal political and social factors in the shaping of their development. Building on an extensive research of a mass of documentary data (letters, papers, manuscripts, photos, drawings) stored in the main in the Archives of the Archaeological Society at Athens (many of which were saved due to his own tireless efforts), in the Archives of

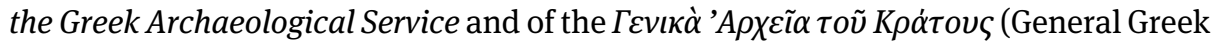
State Archives) and taking advantage of the extent of his first-hand information and personal memories, he achieved the Herculean task of having published (until now) no less than 22 monographs as well as 385 articles on the subject, the majority of the latter in the journal Mentor, telling us, among other things, attractive stories we would never known otherwise. ${ }^{112}$

\section{Main Works}

Petrakos' intention to write a history of the Greek Archaeological Service was already traceable in the early 1980s, ${ }^{113}$ especially with the publication in 1982 of his $\Delta$ oкi $\mu \iota$

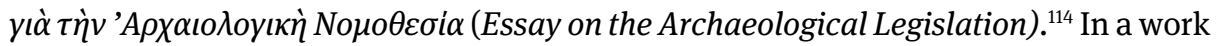
characterized by clear logical thinking combined with cautiousness, he offered for the first time a survey and a comprehensive discussion of the most important archaeological laws passed in Greece from 1834 to 1977. Beginning with the first systematic archaeological law, the Regency act of $1834,{ }^{115}$ a work of Georg Ludwig v. Maurer, which, following the law-model applicable in Rome, set the stage for a professional Archaeological Service and then continuing with Panagis Kavvadias' stricter "On antiquities" law 2456 of $1899,{ }^{116}$ which gave to the state the exclusive right of ownership over all antiquities and its derivative Codified Law 5351 of 1932, ${ }^{117}$ Petrakos discussed in extenso a series of lesser known, but yet groundbreaking laws, namely the works of Ioannis Kontis, passed during the period 1960-1966. One of them (the Royal decree 632 of 1960) led to the transfer of the direction of the Archaeological Service, sheltered until then within the Ministry of Education, to the Office of the Prime Minister

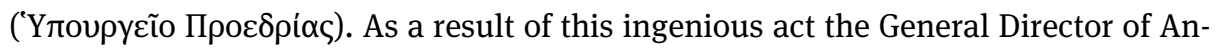

112 See Bibliography at the end of this text. His 22 monographs are the following: 59, 72, 76, 222,

233, 245, 283, 345, 347, 393, 394, 432, 472, 493, 501, 526, 527, 555, 556, 572, 573, 579.

$11355,59$.

11459.

$11559,19-21,123-141$.

116 59, 21f., 94.

11759, 23-28. 
tiquities, at that time Ioannis Papadimitriou (who was together with Kontis the moving spirit behind this project), acquired ministerial rights, ${ }^{118}$ something which gave additional prestige and autonomy to the Service, at least for the short period when the law was in force. The book was dedicated by Petrakos to Ioannis Kontis, his second mentor (after I. Papadimitriou), not only as a recognition of his significant contributions to the field of the Greek archaeological legislation but also to acknowledge his debts to him (for knowledge of the history of the Archaeological Service). ${ }^{119}$ At the time of the Essay's composition he had been Ephor of Attica and its is clear from his own statement in the preface ${ }^{120}$ that the book was intended as an aid offered to the staff of the Archaeological Service. The book, which is didactic in style, has rapidly become the standard text on the subject not only for archaeologists of the Archaeological Service, to whom it was basically addressed, but for all archaeologists who are active in Greece and who had to operate according to the provisions of these laws. The study contained also a systematic attempt to describe the structure of the Archaeological Service and its constitutional parts (Ephoroi, Epimeletes, Archaiologiko Symvoulio).

Two important monographs appeared five years later, in 1987, concerning the

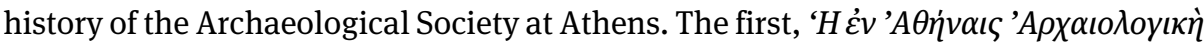

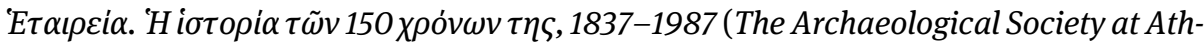
ens. The History of its 150 years, 1837-1987), ${ }^{121}$ was written on the occasion of the 150 th anniversary of the foundation of the Archaeological Society (at the invitation of G. Mylonas). By offering an outline of the organizational breadth of the Archaeological Society's history, it not only updated older versions of the same subject by Efthymios Kastorchis in 1879 and Panagis Kavvadias in 1900, as well as two relevant articles of Georgios Oikonomos ${ }^{122}$ but included also a valuable catalogue of the Society's ex-

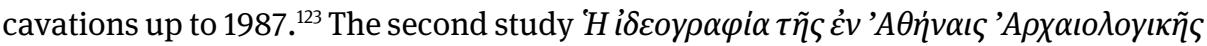

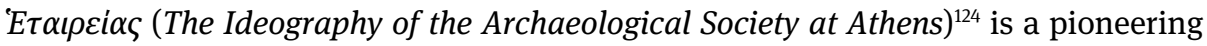
attempt to reveal the Society's intellectual unity throughout its existence, despite the political, ideological and personal differences of its members.

After Petrakos became General Secretary of the Archaeological Society (1988) he expanded the topics of his 1982 Essay on Archaeological Law to include important articles on the antiquities law, on issues of ethics and prosopographical matters, among

118493 I, 436.

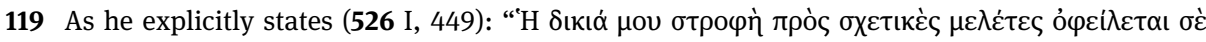

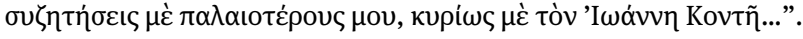

$12059,9$.

12176.

$12276,12$.

$12376,343-372$.

12472. 
other matters. Almost all of these articles appeared in the newly founded journal Mentor, which contained mainly contributions related to the history of the Greek archaeology.

Petrakos next important monograph appeared in 1994. It was a study about the position of Greek antiquities and Greek achaeologists during World War II and the period of the Nazi occupation of Greece (1940-1944). ${ }^{125}$ With this work he presented for the first time, in a comprehensive way, the coordinated activities and attitudes of the Greek archaeologists concerning the protection of the antiquities during the period of Germany's military administration. His story illuminates vividly the protection measures, especially the hiding of the antiquities in the cellars of the museums both in Athens (National Archaeological Museum, Acropolis Museum) and outside Attica (Museum of Delphi, Olympia etc). ${ }^{126}$ Furthermore he discussed the role of the newly established Nazi institutions related to the antiquities in Greece, especially the Kunstschutz for Greece. ${ }^{127}$ This valuable study was the result of original research based on a variety of documentary sources (papers, letters, manuscripts and notes) stored in the Archive of the Archaeological Service, the Archaeological Society's archive but also on letters of Hans Ulrich v. Schönebeck, the director of Kunstschutz for Greece, which are stored at the University of Cologne. ${ }^{128}$

The publication one year later (1995) of his well-known book entitled ' $H \pi \varepsilon \rho \iota \varepsilon \dot{-}$

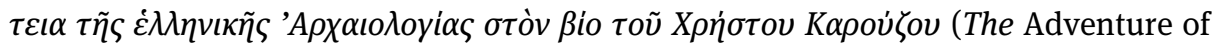
Greek Archaeology in the life of Christos Karouzos) $)^{129}$ is a milestone in the history of the archaeology of Greece for several reasons. First of all, Petrakos defined for the first time the framework within which institutionalized archaeology in Greece has been carried out and divided this timeframe into six main periods: ${ }^{130}$ (1) the period 18341885 (L. Ross, K. Pittakis, P. Efstratiadis and P. Stamatakis), (2) the period 1885-1909 (P. Kavvadias), (3) the period 1909-1933, (4) the period 1933-1958 (Georgios Oikonomos and of the University professors), (5) the period 1958-1967 (I. Papadimitriou and I. Kontis) and (6) the period 1967-1995 (the period of decline). The book bears, furthermore, striking evidence for Petrakos' use of prosopography as a historical tool in order to investigate not only the "adventurous" development and structure of the institutionalized Greek Archaeology during the period of the 48 years of Karouzos' archaeological action (between 1919 and 1967), but also to examine the social aspect of the work of the Greek archaeologists during this period. Focusing on Karouzos as a historical figure and using original archival material, Petrakos studied his correspondence, contacts and connections with other persons, often of very different

125222.

126 222, 87-102.

127 222, 117-128.

128 222, 177.

129233.

130 233, 22. 
ideological and intellectual background. A number of biographies of persons linked to Karouzos, among them Ioannis Miliades, Georgios Oikonomos, Apostolos Arvanitopoulos, Spyridon Marinatos, Antonios Keramopoullos, Phoibos Stavropoullos, Markellos Mitsos, Ioannis Papadimitriou and Ioannis Kontis were presented in this book, too, for this reason. But these are not individual biographies by themselves, at least not in the literal sense of the word, since they were used by Petrakos only in order to provide information about the general picture. By comparing and contrasting these persons with Karouzos he was able to reveal and determine specific configurations and patterns, such as the "wars" between ideologically opposed Ephors and University Professors (Karouzos, Papadimitriou and Kontis versus Oikonomos, Marinatos and Nikolaos Kontoleon) or between older and young members of the Archaeological Service (Karouzos versus Vasileios Kallipolitis). ${ }^{131}$ Hereby he offered insights into the social and political dynamics of Greek society following World War I until the regime of the Colonels in 1967. It is interesting to note that the same applies in the case for Karouzos. Petrakos' Karouzos is the "leader of the branch of the archaeology" in the post-war-period Greece not because he was a brilliant mind or a powerful individual but because "it was he who represented the scientific-national intentions of the archaeologists of the Service". ${ }^{132}$ Again the idea behind such statements is that the individual and exceptional (here Karouzos) is important only insofar as it represents the collective, which in our case are the archaeologists of the Archaeological Service as a whole.

This approach was, of course, not something that appeared here for the first time in Petrakos' work. It has been amply and well demonstrated already before this time (mid-1990s) with a number of "biographies” of Greek archaeologists, especially those of the 19th century, such as Kyriakos Pittakis, Panagiotis Efstratiadis, Panagiotis Stamatakis, Stephanos A. Koumanoudis, Panagis Kavvadias, Valerios Stais, but also those of the 20th century such as Ioannis Papadimitriou, Ioannis Kontis, Ioanna Konstantinou, Ioannis Travlos, Georgios Mylonas and Pavlos Lazaridis or even of foreign archaeologists, whose work was associated with any of the above, such as Wilhelm Dörpfeld and René Ginouvès. ${ }^{133}$ Given the quantity of his biographies, one gains the impression that his main aim was to create a database of persons related to the basic institutions of protecting and investigating Greek antiquities, a 'Who's Who' in Greek Archaeology in order to detect the common elements that connect these individuals.

$131233,155$.

132 233, 179.

133 Kyriakos Pittakis: 96, 115, 199, 432; Panagiotis Efstratiadis: 80, see also 394; Panagiotis Stamatakis: 105, 178, 179, see also 297, 568; Stephanos A. Koumanoudis: 85, 95, 101; Panagis Kavvadias: 176, 572; Valerios Stais: 130; Ioannis Papadimitriou: 84, 164, see also 255, 257; Ioannis Kontis: 89, see also 261; Ioanna Konstantinou: 90; Ioannis Travlos: 219; Georgios Mylonas: 102, see also 501, 592; Pavlos Lazaridis: 170; Wilhelm Dörpfeld: 112; René Ginouvès: 224. 
This claim is supported by a statement of Petrakos in his Ideography of the Archaeological Society at Athens: ${ }^{134}$ "The Archaeological Society", he writes, "is an abstract concept, it does not have a separate existence. It is the result of the work of the people who made it. If we substract even one portion from it, it ceases to be complete and the

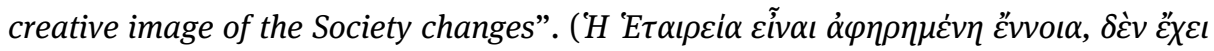

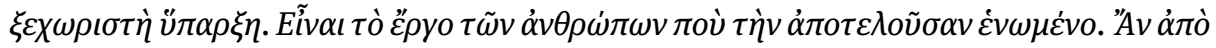

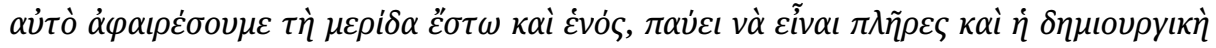

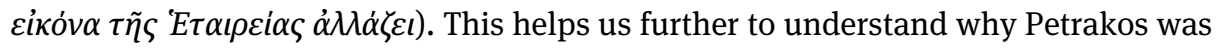
never interested to write an archaeological biography of a powerful individual such as Heinrich Schliemann or Arthur Evans, although both played a decisive role in the development and autonomy of Greek archaeology. Schliemann, for example, is not considered by Petrakos for his great achievements, but he is seen purely in a negative way, through the eyes of Stamatakis, his overseer at Mycenae, who represented the Archaeological Society and the Greek State ${ }^{135}$ and accordingly, the collective eye. Although this approach certainly emphasizes Petrakos' desire to give one underappreciated Greek archaeologist, as indeed Stamatakis was, his due, both for his role in protecting antiquities as well as for documenting and saving Schliemann's excavated monuments and finds and therefore advancing the knowledge of the past, ${ }^{136}$ the decisive element is here, in our opinion, the fact that the Ephor Stamatakis, "one of the most significant Greek archaeologists of the 19th century", a person who represented the Greek state, i.e. the common conceptual framework of the Greeks, ${ }^{137}$ was offended by the arrogant actions and attitudes of Schliemann and his wife.

In the following years, Petrakos added new biographies to his database. With the exception of some persons active in the the 19th century such as the painter Athanasios Iatrides and the historian of modern Athens Dimitrios Kambouroglou, the time span of all the others covered the whole 20th century. These include archaeologists such as Christos Tsountas, Vasileios Leonardos, Nikolaos Zapheiropoulos, Spyridon Marinatos, Sotirios Dakaris, Varvara Philippaki, Anastasios Orlandos, Georgios Oikonomos, Nikolaos Papachatzis, Maria Theochari, Athena Kalogeropoulou, Maria Oikonomakou, Panagiotis Velissariou, Georgios Dontas, Semni Karouzou, Eos Zervoudaki, Stylianos Alexiou, Georgios Despinis, Nikolaos Yalouris, Spyros Iakovidis, Angelos Delivorrias, the architect Aristeidis Passadeos, the numismatist Manto Oikonomidou, foreign archaeologists such as Humfry Payne, Pierre Amandry and Luigi Beschi, historians like Michael Sakellariou and Tasos Gritsopoulos, the art historian Chrysanthos Christou, the egyptologist Jean Leclant, as well as persons from

$13472,185$.

$135297,38$.

$136297,41$.

137 A similar view can be found in the Mentor of the year 1995: the power of the Ephors is "natural" because they "represent and protect the interests of the Greek people” $(\mathbf{2 3 4}, \mathbf{3})$. 
the field of art and literature who had a certain relationship to the World of the Greek Antiquities or the Greek consciousness in general, such as the linguist Dikaios Vagiakakos, the politicians and writers Angelos Vlachos and Maurice Druon, the writer and heroic soldier Patrick Michael Leigh Fermor, the poet Kiki Dimoula, the theatre director Spyros Evangelatos, and the archaeological photographer Nikolaos Tombazis. ${ }^{138}$ Part of this prosopographical work was illuminated in a brilliant photographic exhibition, which took place in 2011 at the Central Building of the Archaeological Society. The exhibition featured the work of some of the most important Greek archaeologists, especially excavators, who have shaped the continuity of the history of the Archaeological Society from 1837 to $2011 .^{139}$

In the last decade (2009-2019), building basically on this prosopographical method and work as well in publishing a mass of up to then unknown or unedited papers, Petrakos turned to what would be the culmination of his systematic historiography of Greek archaeology. Four monumental monographs testify to this:

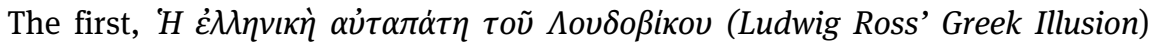
(2009), uses Kyriakos Pittakis as the protagonist of his story, in order to feature the bureaucratic and scientific aspects of the Greek archaeology during this early period, the period of Otto's reign (1833-1863). The book illustrates the indigenous scientific shortcomings of the Archaeological Service during the first decades after the successful end of the War of Independence. This was effected in particular by contrasting Pittakis' views against those of Ludwig Ross on several important issues, such as the freedom of scientific research (case of the Athenian Navy Lists, found by Ross in Piraeus in 1834, which finally led to Ross' displacement from his post as Ephor of Antiquities of Greece in 1836) $)^{140}$ or the view on the Greek past, which in the case of Pittakis was not far from a hero-cult. In contrast to earlier works in Greek scholarship, Petrakos here places emphasis on the different intellectual and scientific backgrounds of the persons responsible for the scientific archaeological policy of Greece.

138 Athanasios Iatrides: 288, see also 526 I; Dimitrios Kambouroglou: 420; Christos Tsountas: 529; Vasileios Leonardos: 573; Nikolaos Zapheiropoulos: 248 Spyridon Marinatos: 527, 528; Sotirios Dakaris: 249; Varvara Philippaki: 264; Anastasios Orlandos: 291; Georgios Oikonomos: 316; Nikolaos Papachatzis: 325; Maria Theochari: 352; Athena Kalogeropoulou: 359, 521; Maria Oikonomakou: 388; Panagiotis Velissariou: 387; Georgios Dontas: 490, 491; Semni Karouzou: 225, 263, 473, 474; Eos Zervoudaki: 417; Stylianos Alexiou: 505, 512; Georgios Despinis: 516; Nikolaos Yalouris: 476; Spyros Iakovidis: 497, 499, 514; Angelos Delivorrias: 567, 570; Aristeidis Passadeos: 389; Manto Oikonomidou: 570; Humfry Payne: 269; Pierre Amandry: 379, 380; Luigi Beschi: 531; Michael Sakellariou: 515; Tasos Gritsopoulos: 419; Chrysanthos Christou: 542; Jean Leclant: 367, 376, 468; Dikaios Vagiakakos: 541; Angelos Vlachos: 327, 333, 335; Maurice Druon: 435; Patrick Michael Leigh Fermor: 467; Kiki Dimoula: 328, 506, 564; Spyros Evangelatos: 551; Nikolaos Tombazis: 425.

139472.

$140432,84-112$. 


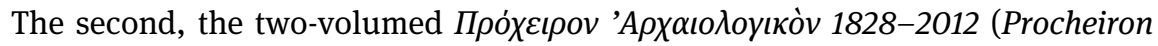
Archaiologikon 1828-2012) (2013), ${ }^{141}$ is Petrakos' most recent attempt at imposing order on the development of scientific archaeology in Greece from 1828 to 2012, hereby heavily revising many aspects of his 1982 Essay and in some cases also his 1995 Adventure. By stressing the existence of further important changes within the time frames of his initial six period-definition of Greek scientific archaeology, Petrakos succeeded in more sharply subdividing in his own periodization. The whole time span is now divided in 16 periods: (1) the period 1828-1829 (the first period of I. Kapodistrias), (2) the period 1829-1832 (A. Moustoxydis), (3) the period 1834-1863 (L. Ross/ K. Pittakis), (4) the period 1864-1885 (P. Efstratiadis/P. Stamatakis), (5) the period 1885-1898 (P. Kavvadias' first period), (6) the period 1898-1909 (P. Kavvadias' second period), (7) the period 1910-1925 (the period of the heads of departments), (8) the period 1925-1933 (the second period of K. Kourouniotis) (9) the period 1933-1938 (G. Oikonomos/Sp. Marinatos), (10) the period 1940-1944 (WW II and Nazi occupation), (11) the period 1945-1958 (the post-WW II era), (12) the period 1958-1963 (I. Papadimitriou) (13) the period 1963-1967 (I. Kontis) (14) the period 1967-1974 (Sp. Marinatos), (15) the period 1975-1981 (D. Lazaridis/N. Yalouris), (16) the period of decline (1981-present). Within these newly defined time frames which are, to a large extent, in accordance with the political changes which took place in Greece in the last two centuries, Petrakos arranged chronologically (a) actions and attitudes related to the Greek legislation on the protection of antiquities, ${ }^{142}$ the establishment of archaeological museums, ${ }^{143}$ the architectural restorations, ${ }^{144}$ but also the conducting of archaeological excavations within a controlled environment, the documentation of the excavated material (writing of archaeological publications), ${ }^{145}$ the creation of archaeological journals, the establishment of institutions such as the Archaeological Service and the Archaeological Society at Athens in 1828 and 1837 respectively and the foundation of the foreign schools, ${ }^{146}$ first the French Archaeological School in 1846 and than the others later in the 19th century.

Petrakos' fine periodization is significant for at least two reasons: first, because through the process of the "apostolic succession" he establishes a tradition in Greek institutionalized archaeology, which begins with Andreas Moustoxydis as the first

141493 I-II. As the choice of the title implies (it refers directly to the famous Middle Byzantine lawbook "Prochiron"), the two-volumed work is an archaeological handbook of didactic character addressed this time not just to the Greek archaeologists working in Greece, but to the younger generation: "I wrote this book", he says "because the older (things) must be known to the younger ones" (493 I, 722).

142493 II, 117-190.

143493 II, 215-219.

144493 II, 191-214.

145493 II, 225-246.

146 472, 39-44. 
state archaeologist (in the decree for his appointment of 21.10.1829 he is called "Director and Ephor of the National Museum") ${ }^{147}$ and through L. Ross, K. Pittakis, P. Efstratiadis, P. Stamatakis, P. Kavvadias reaches the Greek archaeologists of the 20th century and thereby the present day. Second, because by making clear that the above defined succession of periods is associated not only with specific persons but in most of the cases also with political changes, he draws attention to the fact that internal political changes in Greece had a greater impact on the development of the scientific archaeology of the country than previously thought. Future works may have to check the validity of such a finely differentiated scheme against some detailed case studies, and how such schemes may help the future study of the history of science.

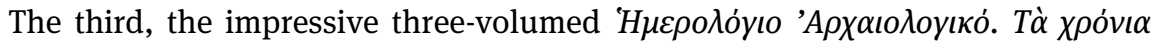

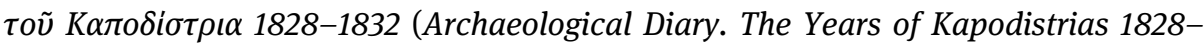
1832) (2015), focuses on the earliest history of the Archaeological Service during the period of the Ioannis Kapodistrias government. Petrakos' narrative of events, based on a thorough analysis of 734 written documents of this period stored in the General State Archives of Greece, on the manuscript archive of the National Library of Greece and on official papers from the Andreas Moustoxydis archive housed at the Metropolis on Corfu, demonstrates emphatically the substantial interest and importance of Kapodistrias' activities concerning the preservation of Greek antiquities. He shows that the "history of Greek archaeology" does not begin in May 1834 with the Regency Act of Maurer but six years earlier: first, with Kapodistrias letter no. 2400/12 May 1828 "to the acting commissioners to the Aegean", in which for the first time it is implied that the Greek antiquities belong to the State, with Panagiotis Anagnostopoulos' circular letter 73 dated on in 7 October 1829, which Petrakos considers (at least the last part of it) as a systematic archaeological law for this early period and thirdly with the foundation of the first National Museum on Aegina (founding law of 21.10.1829). This viewpoint comes into conflict with long-standing prejudices, e.g. that the Service was originated by the Regency, after the destruction of the Aegina museum and the transfer of the antiquities from Aegina to Athens. Petrakos' narrative continues with the analytical description of the work of Moustoxydis, director and Ephor of the first National Museum, a prominent philologist of his time and also familiar with the contemporary European museums, especially the Italian ones. Moustoxydis is the centerpiece of Petrakos' book, and Petrakos has done us a service in stressing his role in protecting and rescuing antiquities in Greek territory during the period 1829-1831, at a time when the borders of the country were reduced to the Aspropotamos-Spercheios line (London protocol of 3.2.1830) and in transferring them (mainly sculptures and inscriptions) to Aegina. Among Moustoxydis' activities, Petrakos highlights a draft decree for the protection of antiquities - somehow strange in its strictness. It became official law only in 1847 , substantially modified.

147526 I, 130; II, 275 no 224. See also 444, 18. 
With this eye-opening publication Petrakos pays tribute to his mentor Ioannis Papadimitriou. It was he who, during his service on Corfu in the period 1931-1948, having found the archive of Moustoxydis in the Metropolis of the Ionian island, initially studied and copied a mass of official papers of the correspondence between Moustoxydis and the acting commissioners. Busy with many and important other duties until his death in 1963, he never finished the task of its publication.

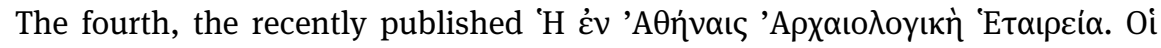
$\pi \rho \tilde{\omega} \tau \varepsilon \varsigma$ $\delta \varepsilon \kappa \alpha \varepsilon \tau i \varepsilon \varsigma ~ 1837-1909$ (The Archaeological Society at Athens. The First Decades 1837-1909) (2019), which is considered by Petrakos as a supplement to his Ideography of 1987, brings together a great selection of archival sources (handwritten acts of the Archaeological Society's Board of Administration, papers of the Society's archive, related records of contemporary newspapers) to illuminate the first 72 years of the turbulent history of the Archaeological Society at Athens, an institution which, especially until 1894, when P. Kavvadias became its Secretary, constituted the most important force within scientific Greek archaeology. From the displacement of Ludwig Ross in 1836 which caused a deep crisis in Greek archaeology and led to the foundation of the Archaeological Society in 6 January $1837^{148}$ through the creation of a scientific institution under the leadership of Stephanos A. Koumanoudis (1859-1894) until Panagis Kavvadias' first secretaryship (1894-1909), the honoree illustrates the Society's difficult transition from the "heroic" period (which according to Petrakos ends with Stamatakis) to the "scientific" era. Covering a period characterized by internal conflicts and division, Petrakos' wide-ranging volume presents the main work carried out by the Archaeological Society during this period, that is the work related to the recovery of Greek antiquities, among others the famous excavations of P. Efstratiadis and P. Kavvadias on the Athenian Acropolis, which yielded one of the most important collections of material in the history of Greek archaeology. Hereby this important book provides the basis for students of Greek archaeology to examine the way scientific work was carried out by Greek archaeologists in the 19th century, their archaeological ideology as well as the Archaeological Society's position in the Greek society of that time.

\section{Central Elements Integral to Petrakos' Concept of Greek Archaeology}

It is not possible to extract from Petrakos' work related to the history of Greek archaeology a single unified view of Greek archaeology. Nevertheless, it is possible to pick out certain recurring themes in his thoughts on the discipline:

(a) Greek Archaeology: The Systematic Attempt to Protect Greek Antiquities. "History of Greek Archaeology" is for Petrakos, as we have seen, above all, "history of protecting Greek antiquities", which comprises mainly the "pragmatic" and "systematic" attempts of mainly Greek and - to a lesser extent - foreign archaeologists to preserve and publish Greek antiquities.

$148572,345$. 
(b) Special Relationship Between Scientific and Legal Archaeology. In his concept of "systematic care for antiquities" and "scientific archaeology" the emphasis is always on archaeological legislation. It is obvious that he chooses this connection to make the point that legal archaeology and science are closely related, indeed inextricable: "Archaeology as a science in Greece, I repeat, takes shape only when it begins to

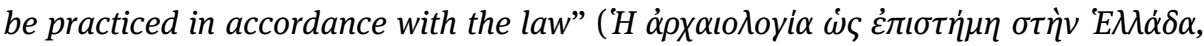

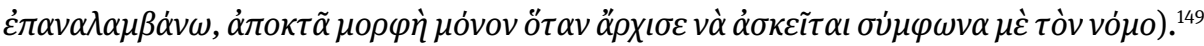

(c) European Style "Ethnocentric" or "Statecentric" Concept. The connection between science and legal archaeology implies that the "true" period of scientific research for Greek antiquities coincides completely with the period of life of the modern Greek nation-state. And indeed, Petrakos' history begins, as we have seen, with the beginning of Kapodistrias' government in 1828 and spans the entire period from 1828 to the present. In this sense one could also describe his work as an attempt to write a "history of Greece's national policy concerning the protection and preservation of the antiquities". Petrakos' concept can, therefore, be regarded somehow as "ethnocentric" or "statecentric", since it abides by the European-style concept concerning the history of the archaeology of a modern nation-state. Earlier attempts to re-discover the classical past in Greece (from the Renaissance until the early 19th century) are excluded from this delineation of research.

(d) Against “Archaeological Nationalism”. Petrakos' writings are not those of a national who tries to "defend" every action or attitude of his native nation-state and/or its population as related to Greek antiquities, and so to produce an aggravating polemic. On the contrary, for the honoree "archaeological nationalism", at least in its definition as a "pseudo-romantic" retrojection onto ancient Greece, either in the form of K. Pittakis' hero-cult or in the emotional connection between the modern population of Greece and the ancient Greek monuments, ${ }^{150}$ should be regarded as one of the greatest threats to Greek archaeology. In his opinion, identification with the ancient Greeks - as expressed in nationalistic archaeology - is a substitute for true identity and represents a regression to an earlier, primitive stage of cultural development.

(e) Against "Self-interested" Individualism. ${ }^{151}$ A common theme in Petrakos' writings, especially in his numerous "biographies" of archaeologists, is to praise the willigness of these archaeologists to do their duty and to handle matters for the benefit of the Archaeological Service, i.e. for the good of the antiquities, even if in this way someone works against his own interests and needs. Collectivistic thinking is implied here, a concept reinforced by the importance he attaches to similar principles such as the unity of the spirit of the members of a group related to the protection and study of

149526 I, VII.

150 Compare for example the case of Amphipolis (533).

151 The plea against the "spirit of scientific individuality" is a common theme in Petrakos' writings (e.g. 296, 22). 
Greek monuments (such as was the case with the Archaeological Society at Athens). Petrakos himself credited this way of thinking to his mentor Ioannis Papadimitriou. ${ }^{152}$

(f) An Aura of Pessimism Permeates Vasileios Petrakos' Sense of History of Greek Archaeology. As he repeatedly explains, the concept of progress, which prevailed in the period 1960-1967, became perverted during the period 1967-1974 and even more so after 1981. His disappointment stems, as one can understand, from the fact that Greek society allowed progress in archaeological matters to become a pawn in the hands of politicians whose goals centered upon political domination rather than upon an active promotion of the principles of the protection of Greek antiquities. This frustration should come as no surprise, since Petrakos belongs to the generation of Greek State archaeologists (employed in the first half of the 1960s), which experienced the adoption of an employment system based on hard work and study (meritocracy). Although the existence of a personal network was a further necessity, the employment was not solely based on personal or/and political connections, as is apparently the case in the later periods. The elimination of their hopes and expectations led them to challenge the notion of progress.

\section{Significance of his Work}

The brief development of the honoree's works related to the history of Greek archaeology presented above bears evidence for an orderly style of thought as well as for an intellectual confidence in handling a combination of complex matters deriving from several scientific fields: in addition to classical archaeology, we should add archaeological ethics, sociological and psychological theory and political science.

Consequently, it is clear that Petrakos' work is invaluable to the study of the history of Greek archaeology. Not just because his highly informative studies are a gold mine for anyone interested in the study of the history of Greek archaeology, but more importantly because he succeeded in transforming a mass of unstructured information related to the protection and systematic investigation of Greek antiquities into solid and normalized public memory. In this sense, Vasileios Petrakos can be considered as one of the "founding fathers of the historiography of scientific Greek archaeology."

\section{Member and Secretary General of the Academy of Athens (2000 to the present)}

In honour of his significant scientific work on Greek archaeology and epigraphy Petrakos was elected in 2000, at the age of 68, Member of the Academy of Athens as a holder of the chair of Archaeology-Epigraphy (fig. 3). From the time of his election (2000) and especially since 2010 as Secretary General of the Academy, Petrakos has

$152164,118$. 
unceasingly fostered the activities of the Academy of Athens with commitment and dedication to his duties.

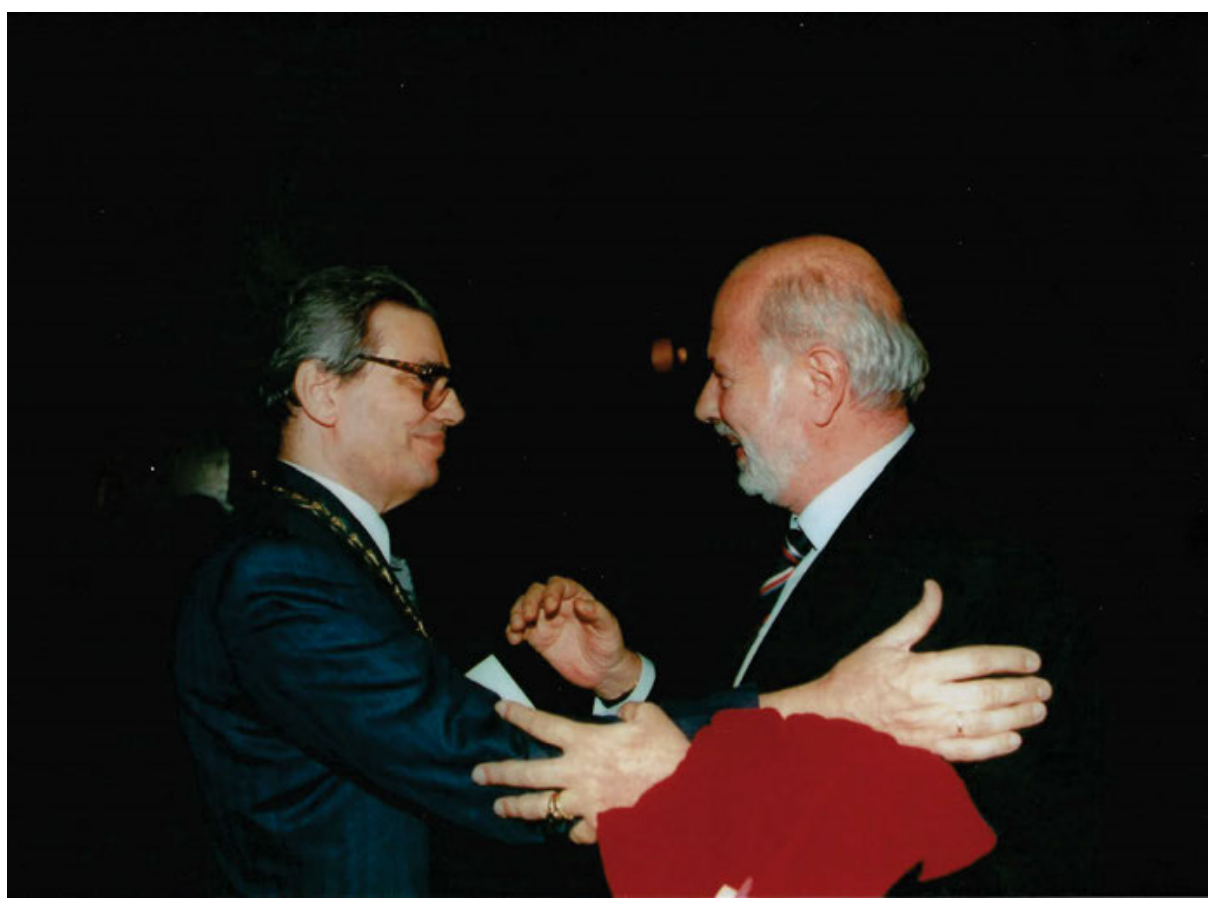

Fig. 3: Angelos Delivorrias (right) congratulating Vasileios Petrakos (left) on becoming member of the Academy of Athens. Photo 2000: Courtesy of D. Vassilikou.

From the beginning of his membership, besides giving substantial and significant public speeches on epigraphical matters, ${ }^{153}$ Petrakos played a central role in creating an interest among the public in the fate of Greek antiquities, especially during turbulent periods such as the period of the Greek War of independence (1821-1828) (54 $^{15}$ or the period of WW II (1940-1944) ${ }^{155}$. As already mentioned, his 2002-2004 initiatives as well as his energetic efforts against the building of the Olympic Centre in the historic site of Marathon were however ignored by the Greek government.

Petrakos' election to the position of the Secretary for the Publications of the Academy (2003-2008) and more so since 2010 as Secretary General of the Academy has given fresh impetus to the production of the Institution's scientific work. As in the 
case of the Archaeological Society, rather than organizing conferences, Petrakos promoted the publication policy of the Academy. Important archaeological projects-databases, lapsed over the course of time, such as the Tabula Imperii Romani (TIR) were now, under his scientific supervision, revitalized. ${ }^{156}$ The same holds true for the pub-

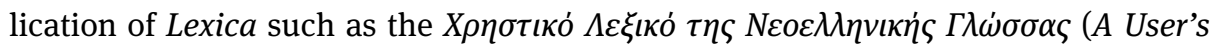
Lexicon of Modern Greek Language) (2014). ${ }^{157}$

Chief among his scientific contributions, which can be placed within the framework of his Academy duties, was the writing of two important monographs and a number of articles on the history and pre-history of the Academy of Athens. His first

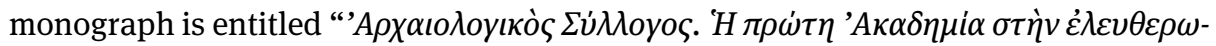

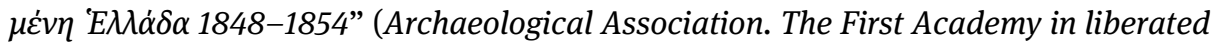
Greece 1848-1854) (2007) and deals with the first ambitious attempt on the part of liberated Greece to create an Academy of Science along the lines of the great western ones from Germany and especially akin to the Académie des Inscriptions et Belles Lettres of the Institut de France. ${ }^{158}$ The whole project was an idea of Alexandros Rangavis, the first Secretary General of the Archaeological Society, who desired to unite all the existing scientific associations in Athens. The results finally did not satisfy Rangavis and the association was dissolved in 1854, during the year of the Athenian plague. However, by focusing closely on this carefully selected organization that existed only over a relatively short period of time (1848-1854), Petrakos succeeded in exploring a number of important issues not only relevant to the history of the "ideas about the Academy" but also to the history of Greek archaeology. His thorough treatment of the subject provides solid evidence for the fact that this small circle of intellectuals, which included beside Rangavis such as P. Efstratiadis and Patriarch Konstantios I, had concrete and original ideas about the use of the past as well as about the role of their Academy within a wider European environment. Petrakos documents thus (a) actions which follow ancient Greek practices, such as the erection of a marble stele with the " $\psi \dot{\eta} \varphi ı \sigma \mu \alpha \tau \tilde{\omega} v E \dot{v} \varepsilon \rho \gamma \varepsilon \tau \tilde{\omega} \nu$ " (decree of the Benefactors) following the donation of Konstantions I, ${ }^{159}$ (b) the practice of sending the publications of their excavations and researches (here the inscriptions from the House of Louisa Psoma in Athens) to esteemed European scholars (to August Boeckh and Ludwig Ross in Germany), ${ }^{160}$ but also (c) matters of archaeological legislation (the right of publication of these inscriptions).

156 See http://www.academyofathens.gr/el/research/centers/antiquity/ekdoseis-2 under "Tabula Imperii Romani”.

157523.

$158394,49$.

$159394,56-61$.

$160394,70-77$. 
Petrakos' second monograph on the subject concerns the 20th century and is en-

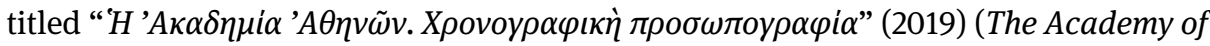
Athens. A Chronographical Prosopography). Following the method he used to reveal the history of the Archaeological Society, Petrakos brings together archival handwritten acts of the Plenary sessions of the Academy, acts of the sessions of the three sections of the institution and the rich relevant material published in the press in order to illuminate the first 93 years of the history of the Academy of Athens, an institution whose foundation, although conceived of in $1824,{ }^{161}$ only came to be in $1926 .{ }^{162}$ The centerpiece of the book is the narrative of persons and events of the second section, in which Petrakos also belongs, and chief among them is the case of Karouzos/Marinatos, i.e. the discussion in the Plenum of the Academy on the election of either Christos Karouzos or Spyridon Marinatos for the chair in archaeology. Both candidates played an important role in the Archaeology of Greece during the post-civil war period in Greece (1952-1954): important persons such as Antonios Keramopoulos, Anastasios Orlandos, Konstantinos Rhomaios and Sokratis Kougeas, who belonged to the social network of one or the other of the candidates, gave speeches in order to defend or to criticise on behalf of their man. In 130 pages ${ }^{163}$ Petrakos documents views which are expressed about the science of archaeology but also about non-archaeological matters such as the political and social ideology of the candidates or the back then intensively discussed Greek language question. This was the time, as Petrakos notes, when it was “a crime to have opposed the other's political views or to write in Demotic Greek". ${ }^{164}$

\section{Distinctions}

In the course of his career Vasileios Petrakos has been a member of numerous boards and committees and has received many honours and awards. He has also served as a member on public committees and councils, among them the Central Archaeological Council (KA $\Sigma$ ) and the Committee for the Conservation of the Acropolis Monuments (ESMA). He acted also as a Secretary General of the XII Conference of Classical Archaeology (1983). He has the distinction of having been awarded the Ministerial award of the Greek Government for the year 1981 and the Marangopoulos foundation award of the Academy of Athens for the year 1986. He is a corresponding member of the German Archaeological Institute in Berlin, member of the Historical and Ethno-

\footnotetext{
161394,5 n. 7.

$162574,25$.

$163574,357-487$.

$164574,487$.
} 
logical Society of Greece, of the Society of Laconian Studies, the Society for Peloponnesian Studies, a lifetime member of the Archaeological Society at Athens and since 1988 its Secretary General, foreign corresponding member (1996) and associate foreign member (1998) of the Académie des Inscriptions et Belles Lettres of the Institut de France, a member of the Academy of Athens as holder of the chair of ArchaeologyEpigraphy (2000), Secretary for the Publications of the Academy (2003-2008), and finally Secretary General of the Academy (2010-present).

\section{Publications (1960-2020)}

\section{Special Abbreviations}

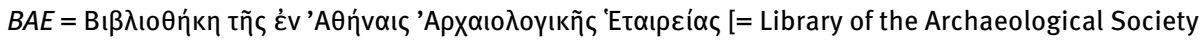
at Athens]

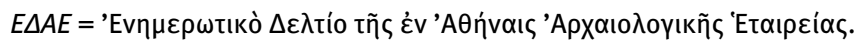

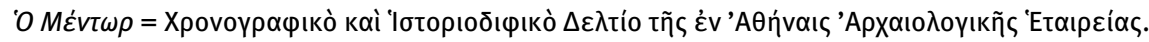

\section{0}

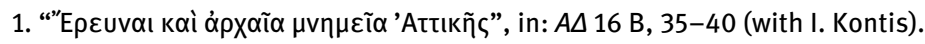

\section{$1961 / 1962$}

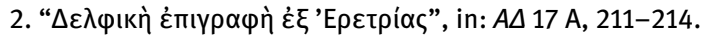

3. “'Атtıк'́", in: $A \Delta 17 \mathrm{~B}, 29-36$.

4. "Eüßoı", in: $A \Delta 17$ B, 144-157.

\section{3}

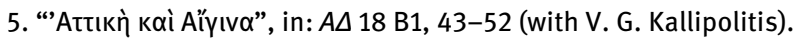

6. "Eüßoı", in: $A \Delta 18$ B1, 121-127 (with V. G. Kallipolitis).

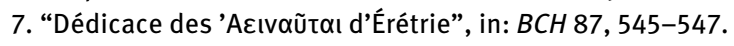

\section{4}

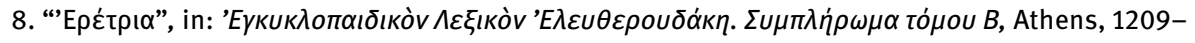
1211.

\section{5}

9. Doctoral Dissertation, University of Lyon, Institut d'épigraphie Grecque - Institut Fernand Courby. Title: Les inscriptions d'Oropos; published in 1997 in a revised and expanded form (see no 252).

\section{6}

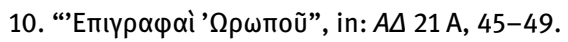

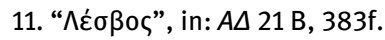

\section{7}

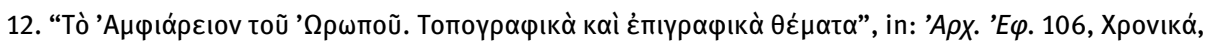
$1-13$. 


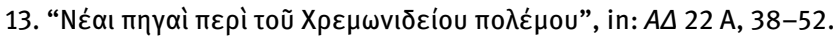

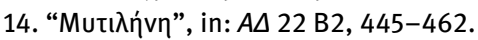

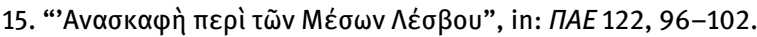

\section{8}

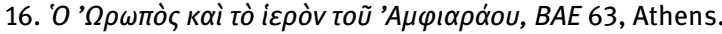

Review: D. M. Pippidi, in: Studii Clasice 12, 1970, $317 \mathrm{f}$

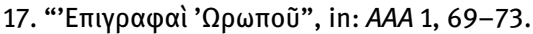

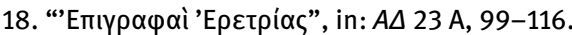

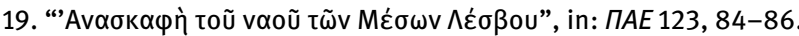

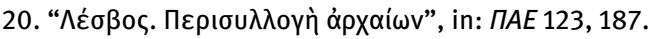

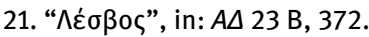

1969

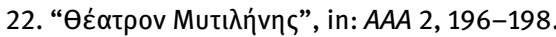

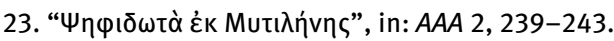

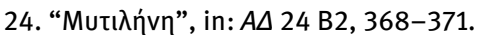

1970

25. “ $\Delta \varepsilon \lambda \varphi o^{\prime}$ ”, in: $A \Delta 25 \mathrm{~B} 1,264$.

\section{1}

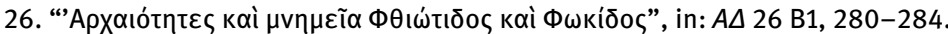

27. $\Delta \varepsilon \lambda \varphi o i$, Athens; English translation of first Greek edition: Delphi, Athens 1971; French translation of first Greek edition: Guide de Delphes, Athènes 1971.

1972

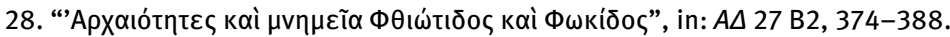

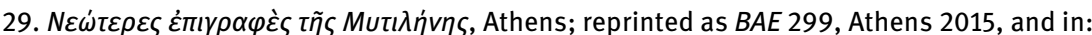

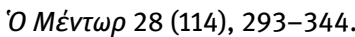

\section{3}

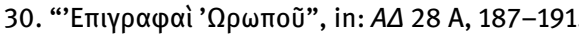

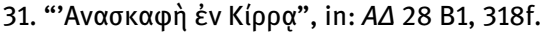

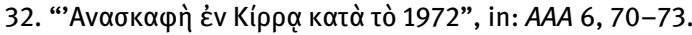

33. “Mitilene”, in: Enciclopedia dell’ Arte Antica, Supplemento 1970, Rome, $498 \mathrm{f}$.

1974

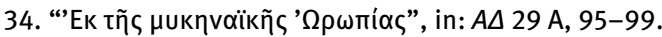

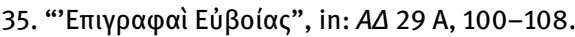

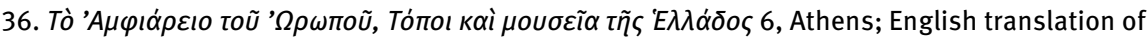
Greek edition: The Amphiareion of Oropos, Sites and Museums of Greece 6, Athens 1974. 1975

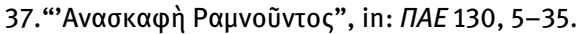

1976

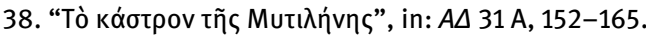

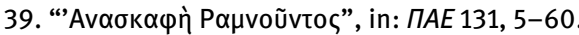


1977

40. $\Delta \varepsilon \lambda \varphi o^{2}$, Athens 1977 (reprint 1997); English translation of second Greek edition: Delphi, Athens 1977; French translation of second Greek edition: Delphes, Athens 1977; German translation of second Greek edition: Delphi, Athens 1977.

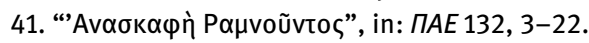

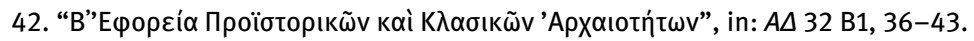

\section{8}

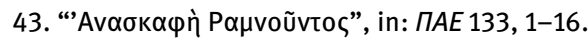

\section{9}

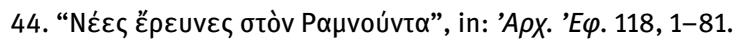

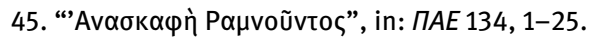

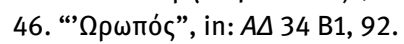

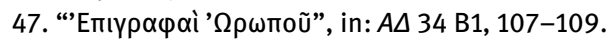

\section{0}

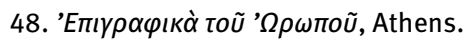

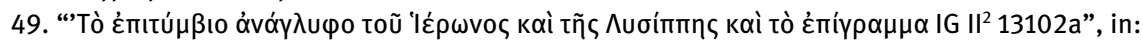

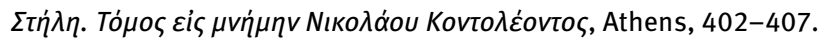

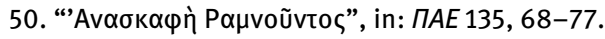

\section{1}

51. “La base de la Némésis d’Agoracrite (rapport préliminaire)", in: $B C H$ 105, 227-253.

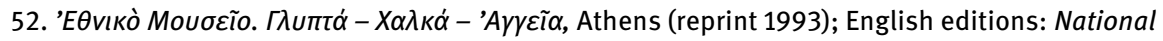
Museum. Sculptures - Bronzes - Vases, Athens (reprints 1993/1998/2000). German edition: Nationalmuseum. Skulpturen - Bronzen - Vasen, Athens 1981.

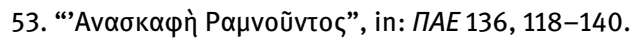

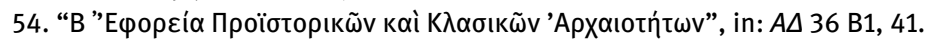

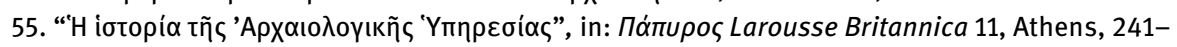
248.

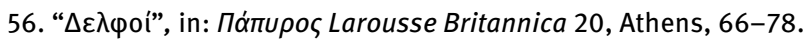

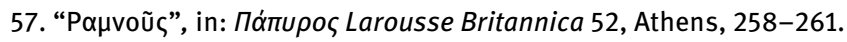

\section{1/1982}

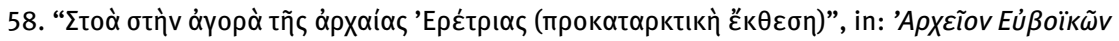

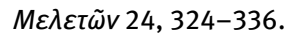

\section{2}

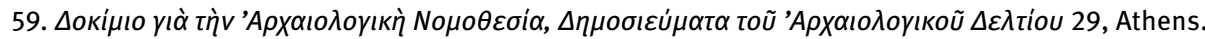

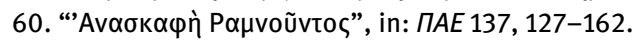

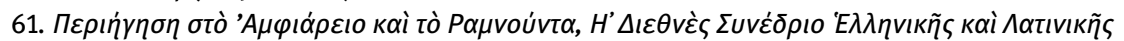

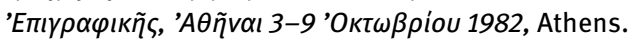

\section{3}

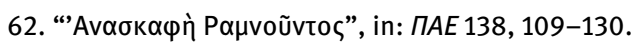

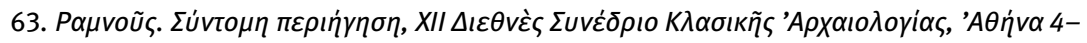
$10 \Sigma \varepsilon \pi \tau \varepsilon \mu \beta$ piou 1983, Athens; English translation of Greek edition: Rhamnous. A Concise 
Guide, XII International Congress of Classical Archaeology, Athens 4-10 September 1983, Athens 1983.

1984

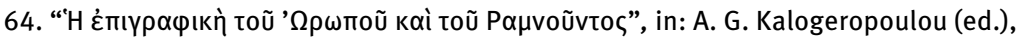
VIII. International Congress of Greek and Latin Epigraphy, Athens, 3-9 October 1982, I, Athens, 309-338.

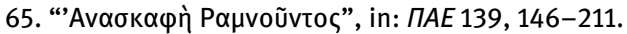

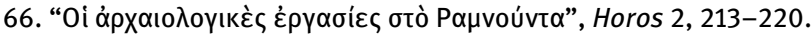

1985

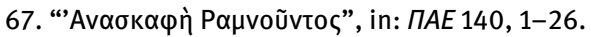

1986

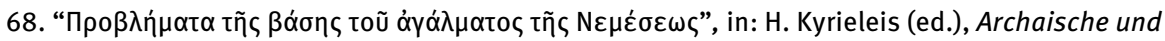
klassische griechische Plastik, Akten des internationalen Kolloquiums vom 22.-25. April 1985 in Athen, II, Mainz, 89-107.

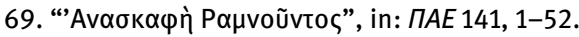

\section{7}

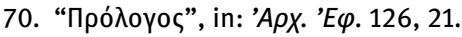

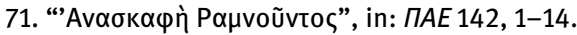

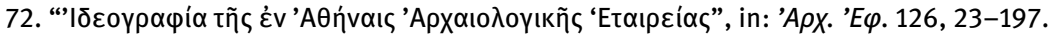

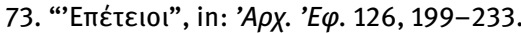

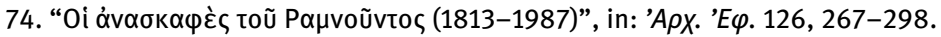

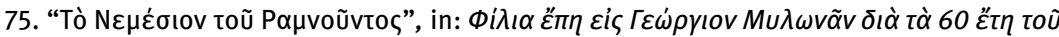

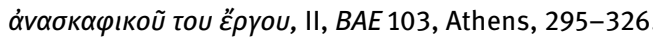

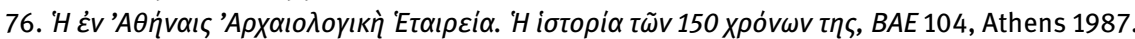

\section{8}

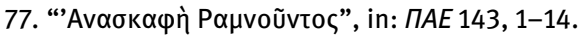

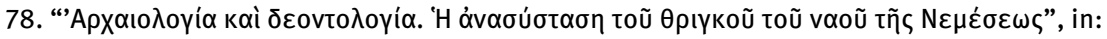

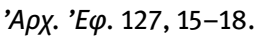

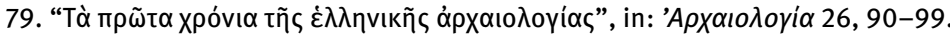

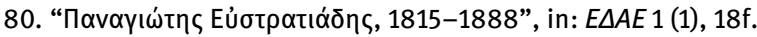

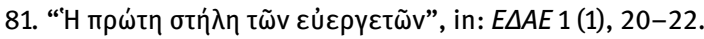

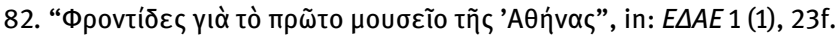

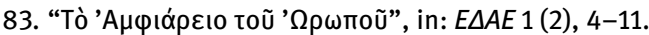

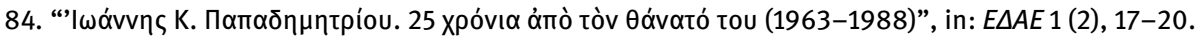

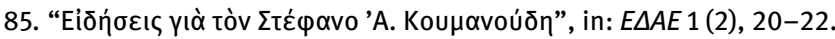

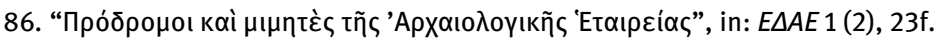

\section{9}

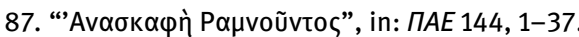

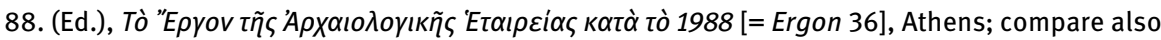
ПAE 143, 1988, к $\theta^{\prime}-\lambda \eta^{\prime}$.

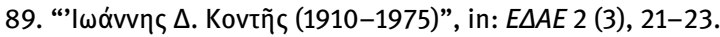

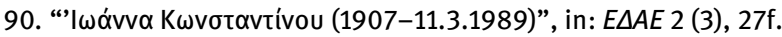

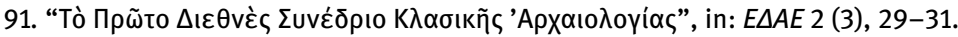




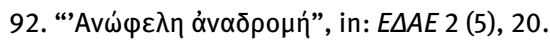

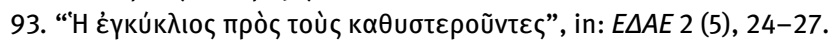

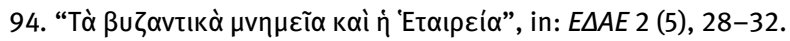

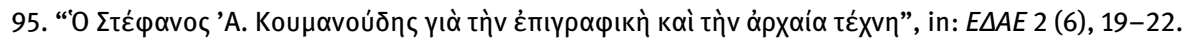

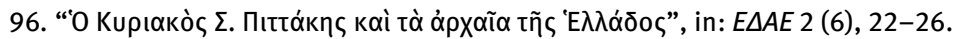

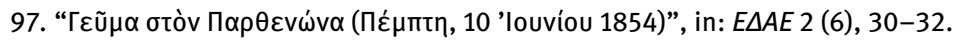

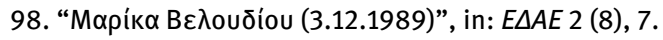

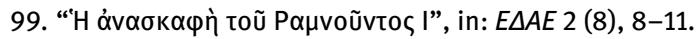

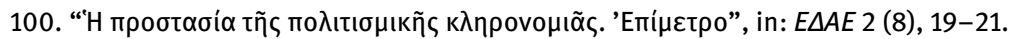

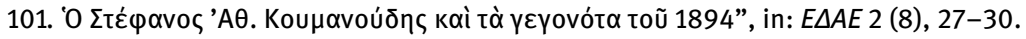

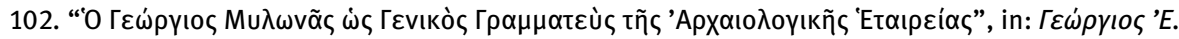

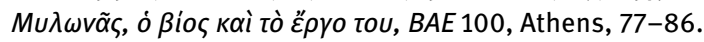

\section{0}

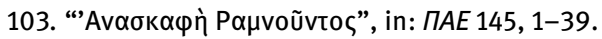

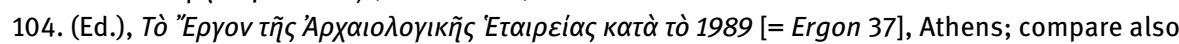
ПAE 144, 1989, $\lambda \zeta^{\prime}-\mu \delta^{\prime}$.

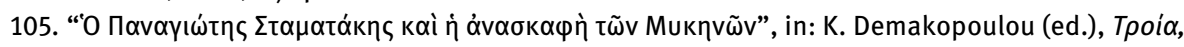

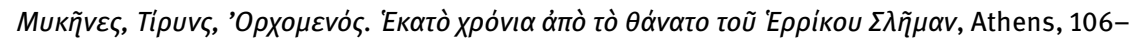
112. English translation of Greek edition: "Panayiotis Stamatakis and the Excavation at Mycenae”, in: K. Demakopoulou (ed.), Troy, Mycenae, Tiryns, Orchomenos. Heinrich Schliemann. The $100^{\text {th }}$ Anniversary of His Death, Athens, 106-112.

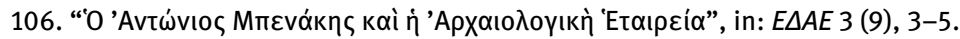

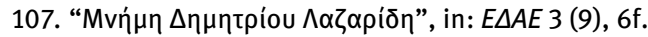

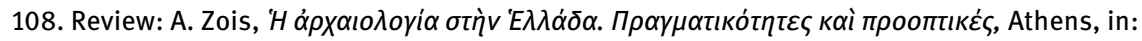
EDAE 3 (9), 8.

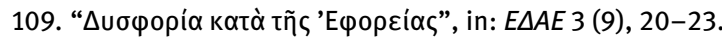

110. "Прòs toùs 'Etaípous", in: ELAE 3 (10), 25-31.

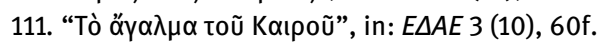

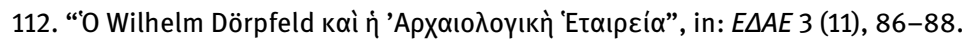

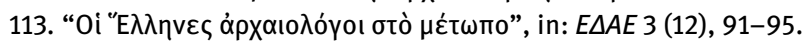

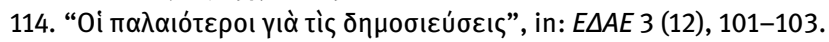

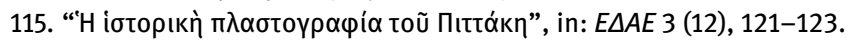

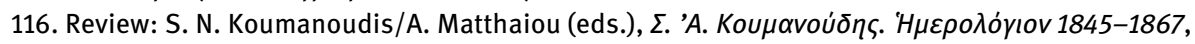
Athens 1990, in: $E \triangle A E 3$ (12), 123.

\section{1}

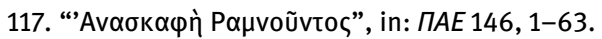

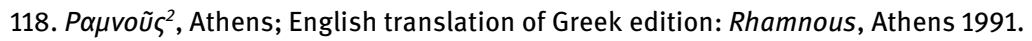

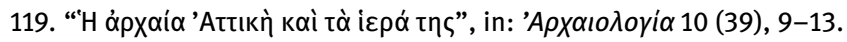

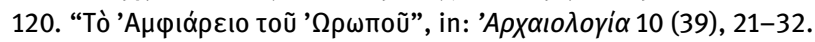

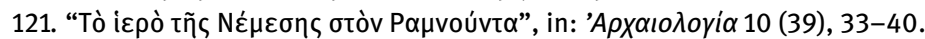

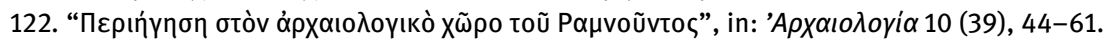

123. “Прó Athens, 17-19.

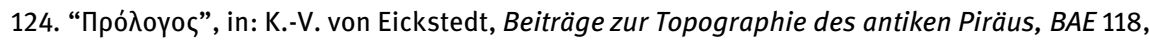
Athens, without page number.

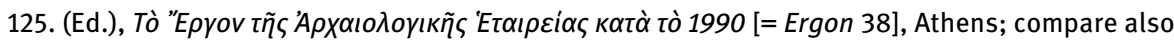
חAE 145, 1990, $\lambda \zeta^{\prime}-\mu \zeta^{\prime}$. 


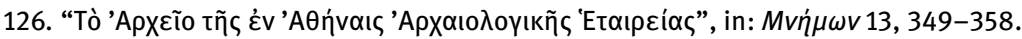

127. "Про̀ toùs 'Etaípous", in: EAAE 4 (14), 1-3.

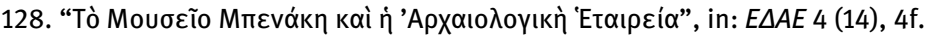

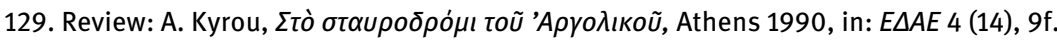

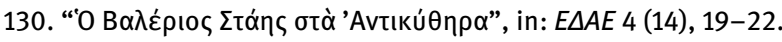

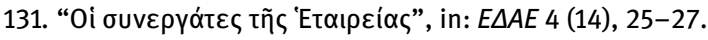

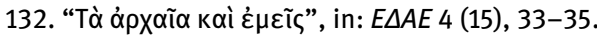

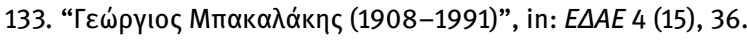

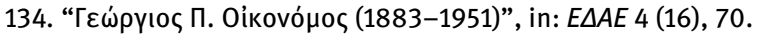

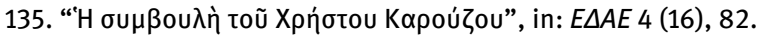

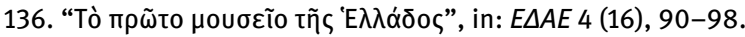

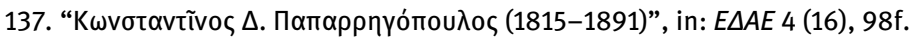

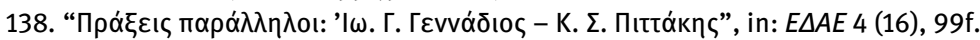

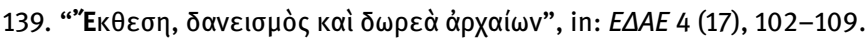

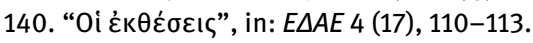

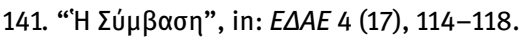

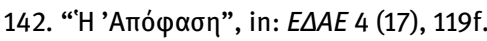

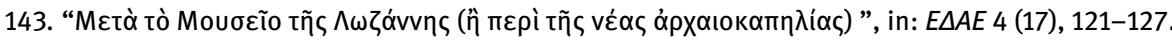

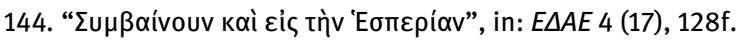

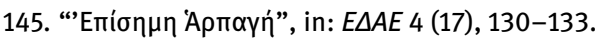

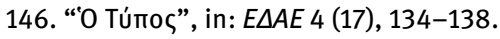

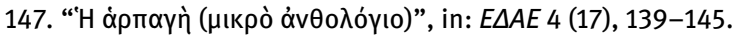

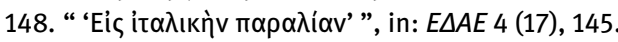

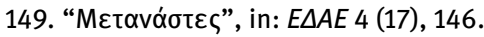

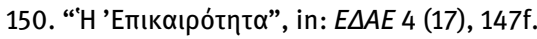

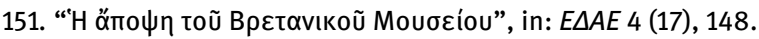

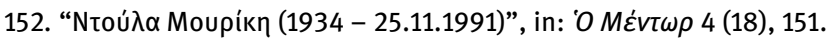

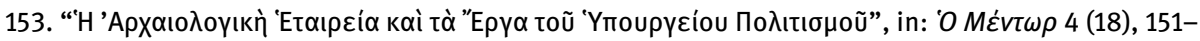
155.

1992

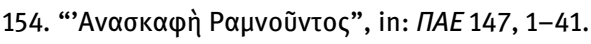

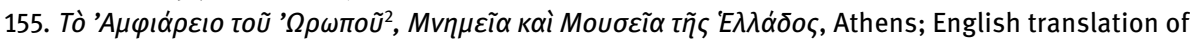
the second Greek edition: The Amphiareion of Oropos, Greece. Monuments and Museums, Athens 1995. German translation of the second Greek edition: Das Amphiaraion von Oropos, Athen 1996.

156. Review: Ch. W. Clairmont, Classical Attic Tombstones, I-VI, Kilchberg 1993, in: 'Apx. 'E $\varphi$. 131, 195-197.

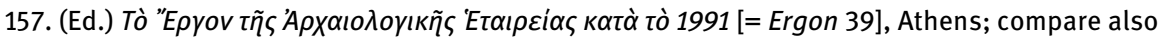
ПAE 146, 1991, $\lambda \varepsilon^{\prime}-\mu \zeta^{\prime}$.

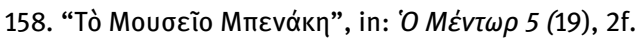

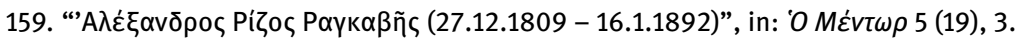

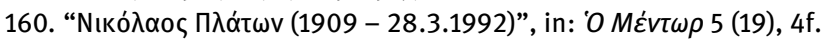

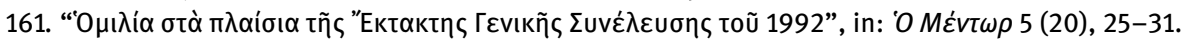

162. "'Епіं

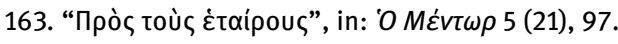

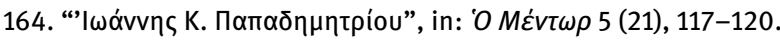

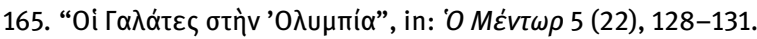

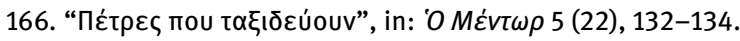




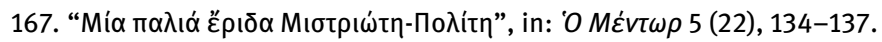

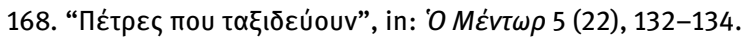

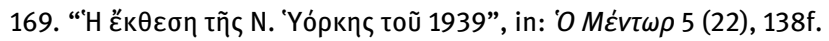

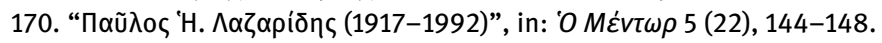

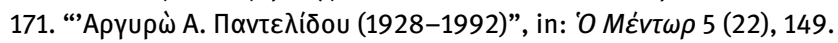

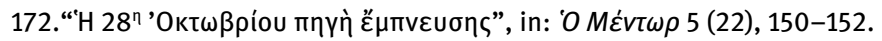

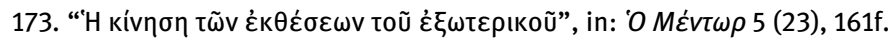

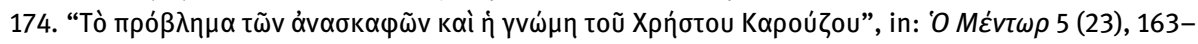
170.

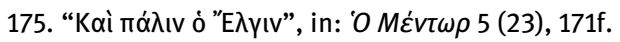

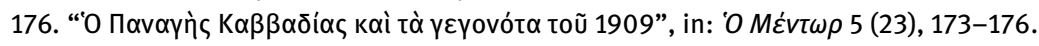

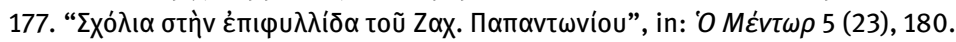

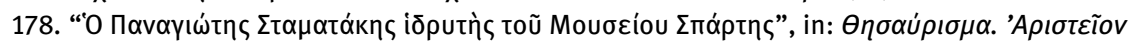

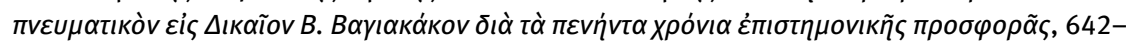
650.

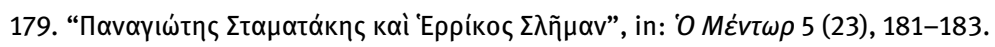

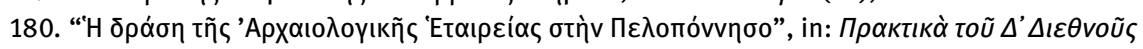

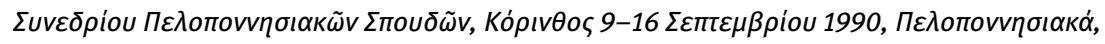

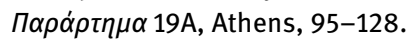

\section{3}

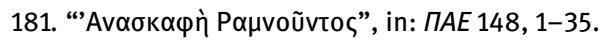

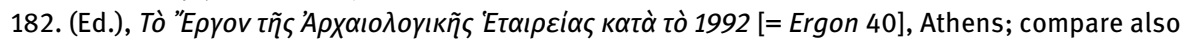
$\Pi A E 147,1992, \lambda \varepsilon^{\prime}-\mu \alpha^{\prime}$.

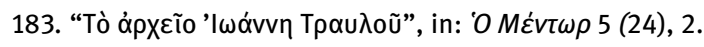

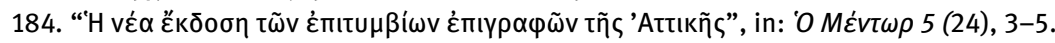

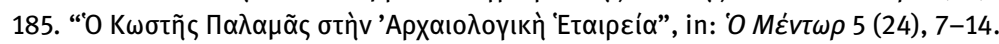

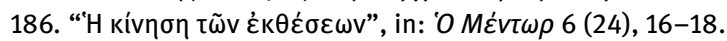

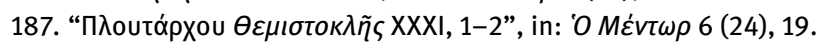

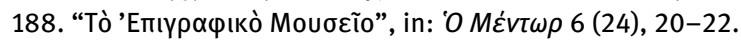

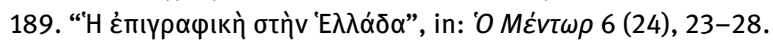

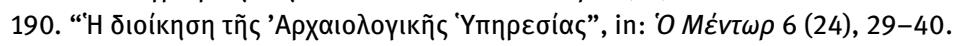

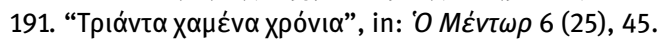

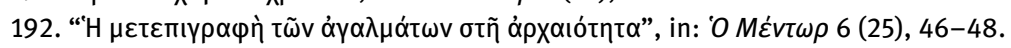

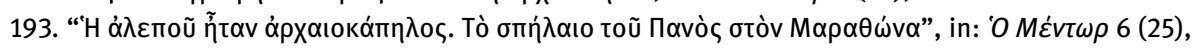
67-70.

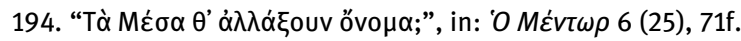

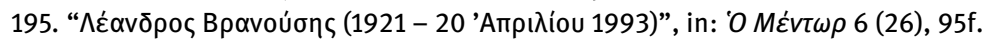

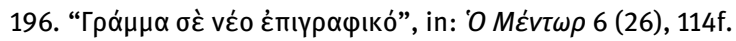

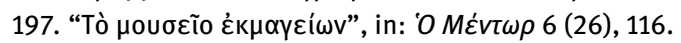

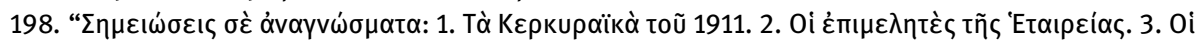

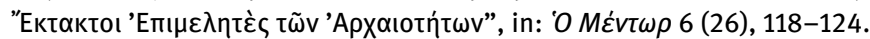

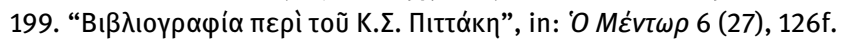

200. “Nó

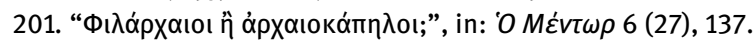

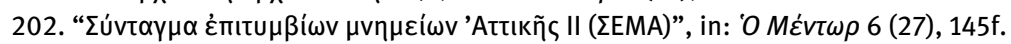

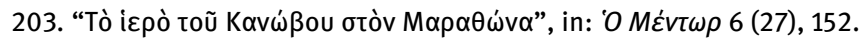

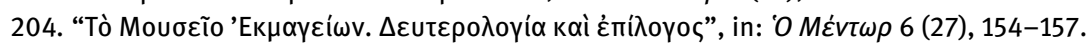

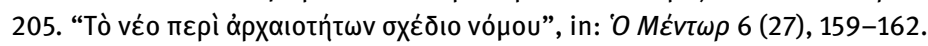




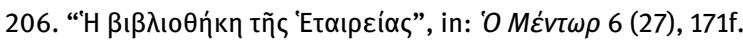

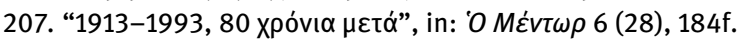

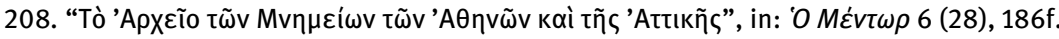

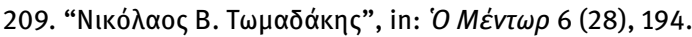

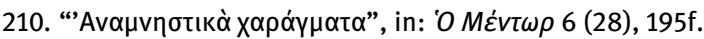

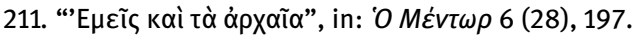

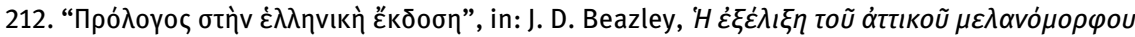
$\rho u \theta \mu o \tilde{,}$ BAE 134, Athens, XIII.

\section{4}

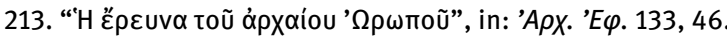

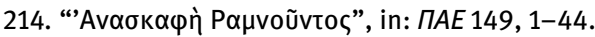

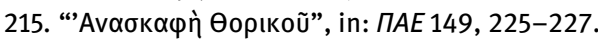

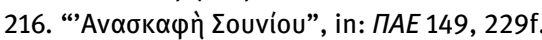

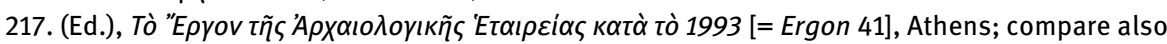
חAE 148, 1993, $\lambda \gamma^{\prime}-\lambda \eta^{\prime}$.

218. "Preface", in: A. Papageorgiou-Venetas, Athens. The Ancient Heritage and the Historic Cityscape in a Modern Metropolis, BAE 140, Athens, XIII.

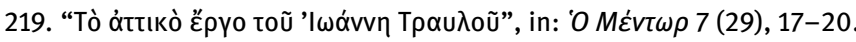

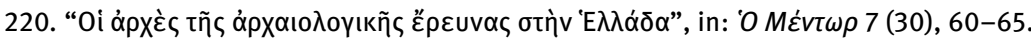

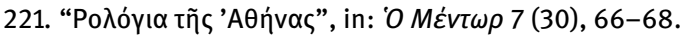

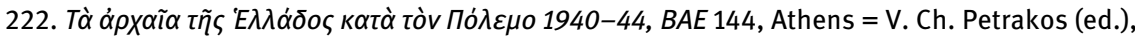
'A

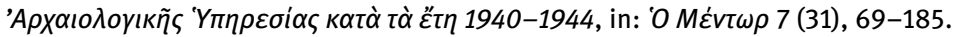

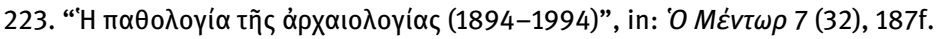

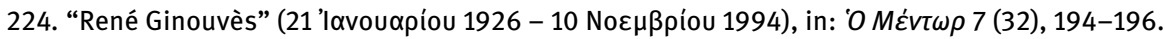

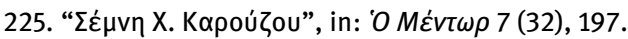

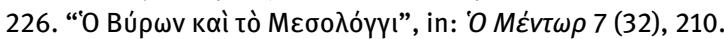

1995

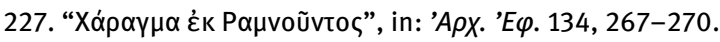

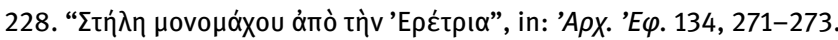

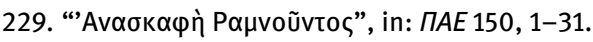

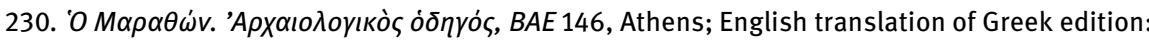

Marathon. An Archaeological Guide, BAE 155, Athens 1996; German translation of Greek edition: Marathon. Ein archäologischer Führer, BAE 172, Athens 1998.

Review: J.-J. Maffre, in: Rev. Arch 114(2) 2001, 693.

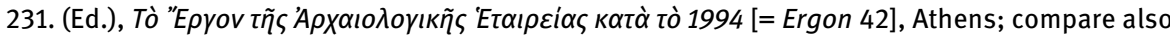
ПAE 149, 1994, ıү'-к $\beta^{\prime}$.

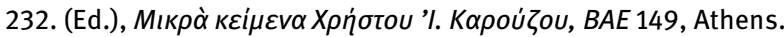

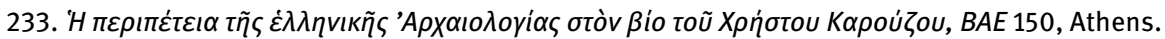

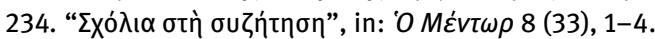

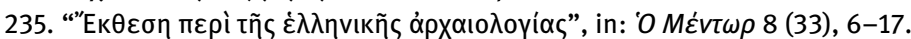

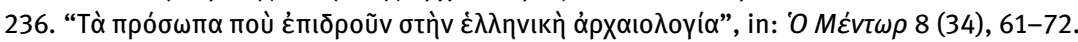

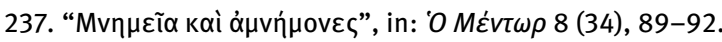

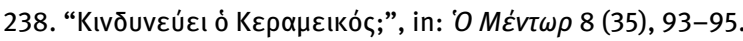

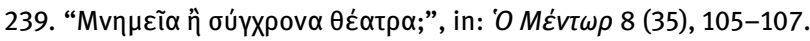

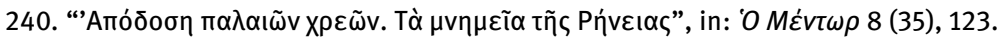

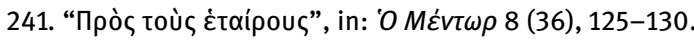




\section{6}

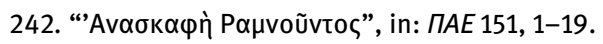

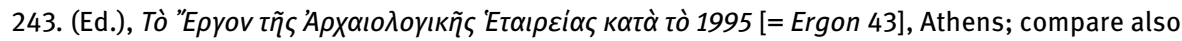
חAE 150, 1995, ıү'-к'.

244. "L’École française d' Athènes vue par les Grecs", in: BCH 120, 501-509.

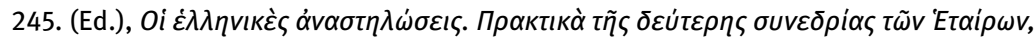
27 'lavouapiou 1996, BAE 154, Athens.

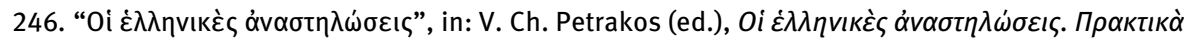

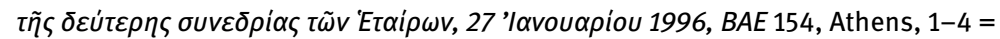

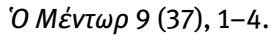

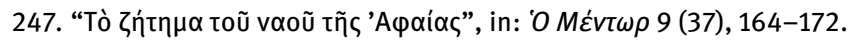

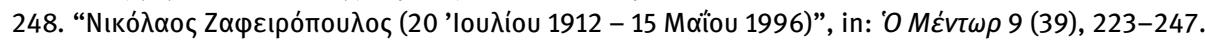

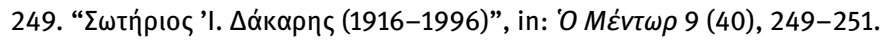

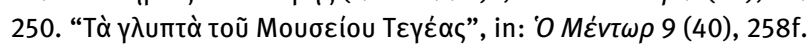

\section{7}

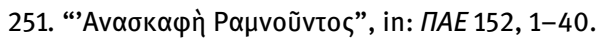

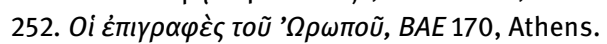

253. "La fortresse de Rhamnonte", in: CRAI 141 (2), 605-630.

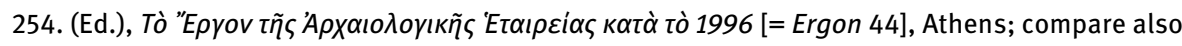
ПAE 151, 1996, ıү'-K'.

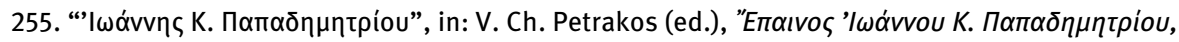
BAE 168, Athens, 9-51.

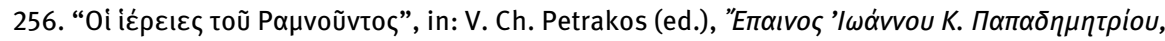
BAE 168, Athens, 405-421.

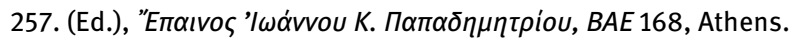

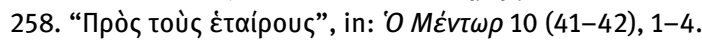

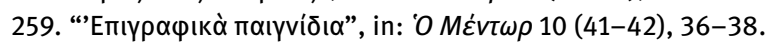

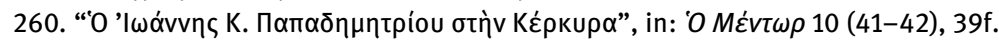

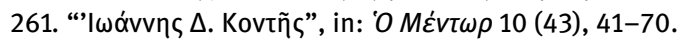

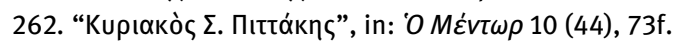

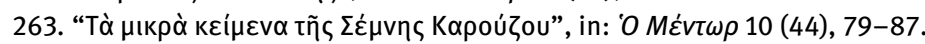

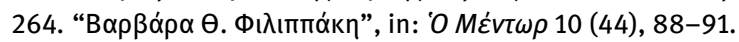

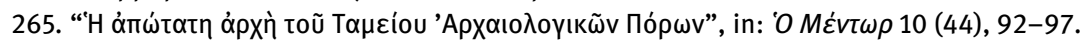

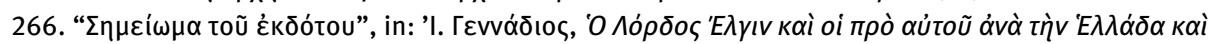

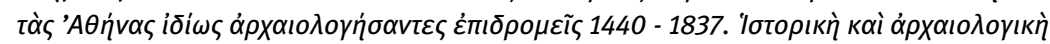
$\pi \rho \alpha \gamma \mu \alpha \tau \varepsilon i \alpha$, BAE 25 (reprint of 1997), Athens, $1 \alpha$ '.

\section{8}

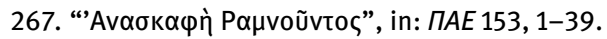

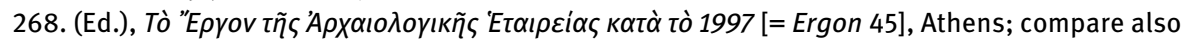
חAE 152, 1997, เү'-1 $\zeta^{\prime}$.

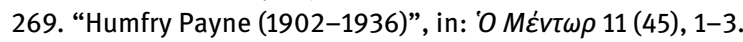

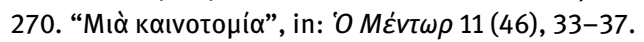

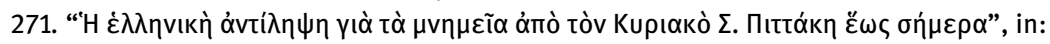

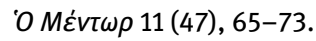

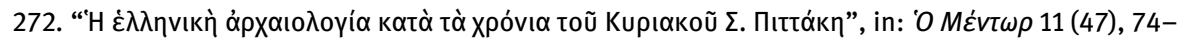
113.

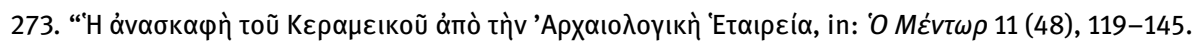




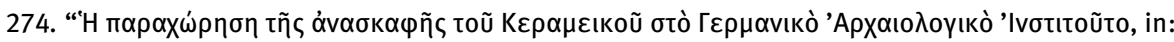
O MÉvt $\omega \rho 11$ (48), 146-149.

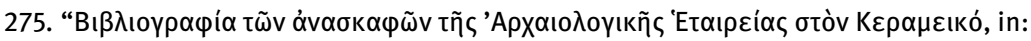

O MÉvt $\omega \rho 11$ (48), 150-162.

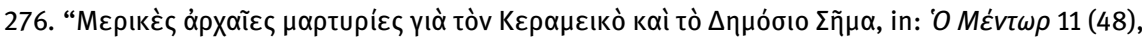
$163-167$.

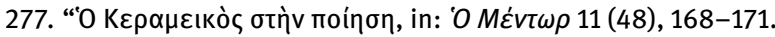

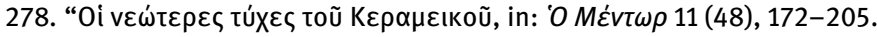

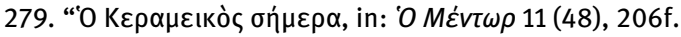

1999

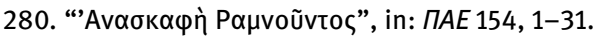

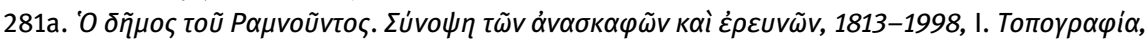
BAE 181, Athens.

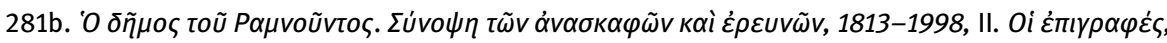
$B A E$ 182, Athens.

Review: J. C. Couvenhes/J.C. Moretti, Topoi 11, 2001, 767-784.

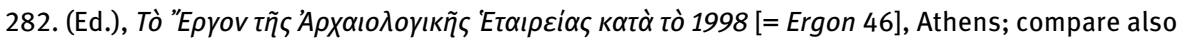
ПAE 153, 1998, เү'-K'.

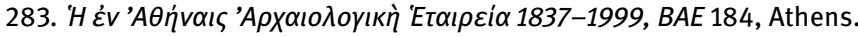

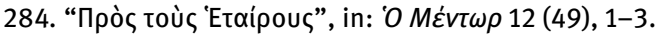

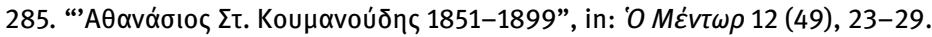

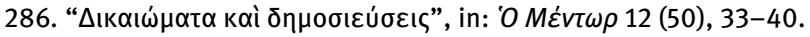

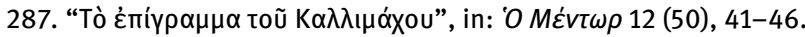

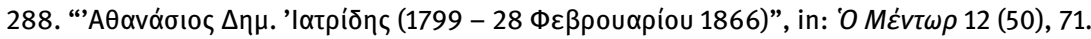

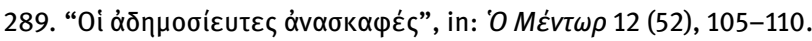

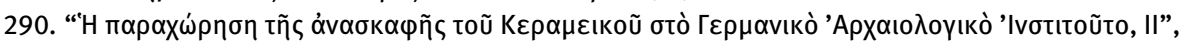

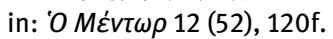

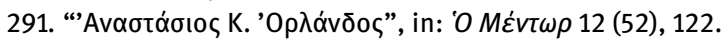

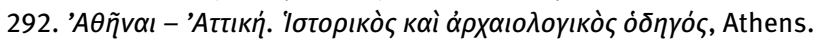

2000

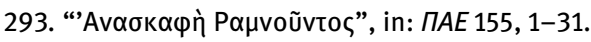

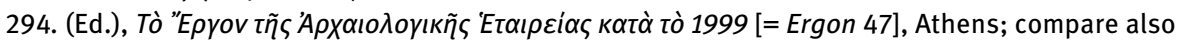
TAE 154, 1999, $\mathrm{t} \gamma^{\prime}-1 \varepsilon^{\prime}$.

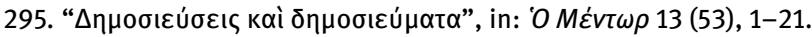

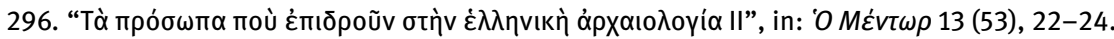

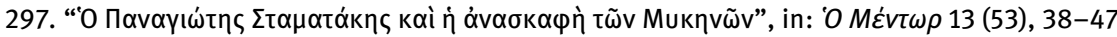
(reprint of no. 105).

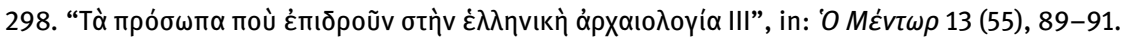

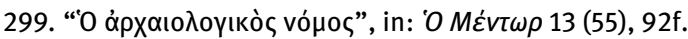

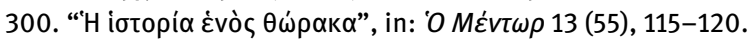

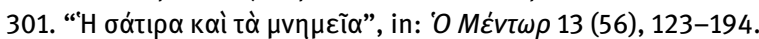

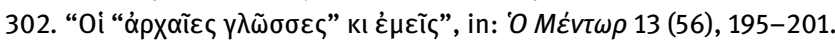

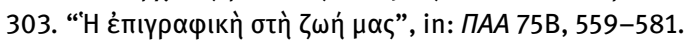




\section{1}

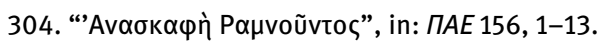

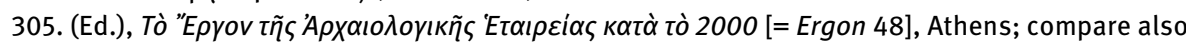
TAE 155, 2000, เү'-к弓'.

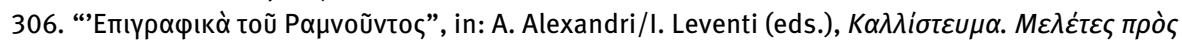

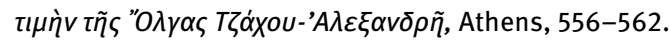

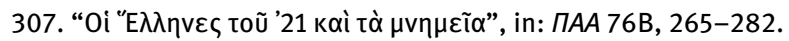

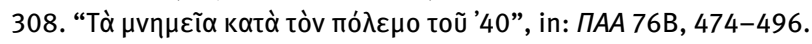

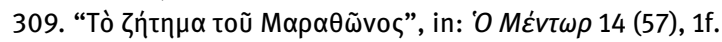

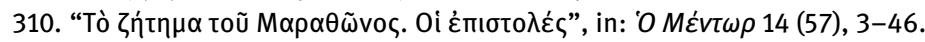

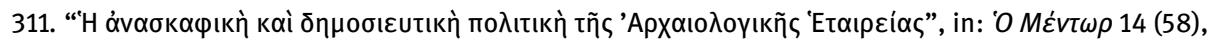
1-59.

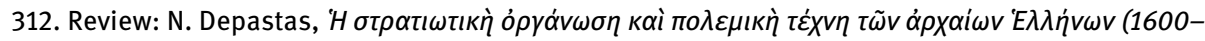

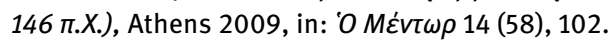

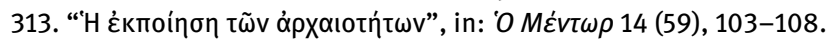

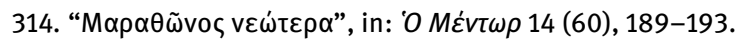

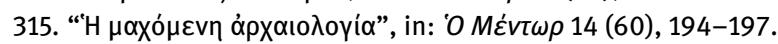

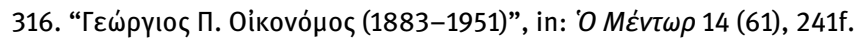

\section{2}

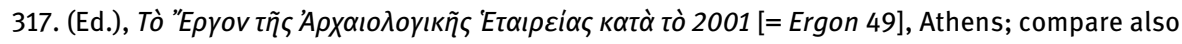
TAE 156, 2001, ıү'-к $\alpha^{\prime}$.

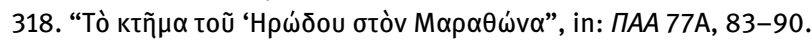

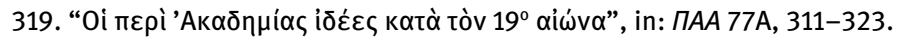

320. Review: A. Cambitoglou/J. K. Papadopoulos/O. T. Jones (eds.), Torone I, The Excavations of 1975, 1976 and 1978, Vol. 1-3, BAE 206-208, Athens 2001, in: ПAA 77B, 407-411.

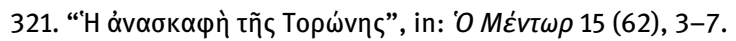

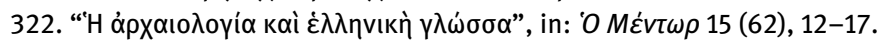

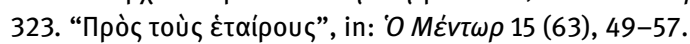

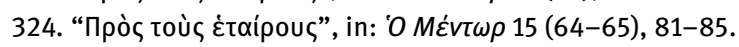

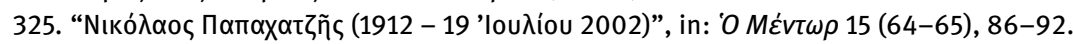

\section{3}

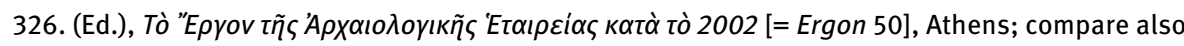
ПTAE 157, 2002, $1 \alpha^{\prime}-1 \theta^{\prime}$.

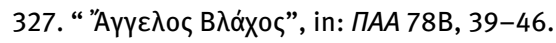

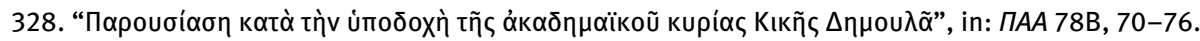

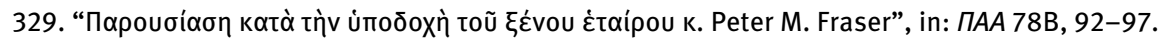

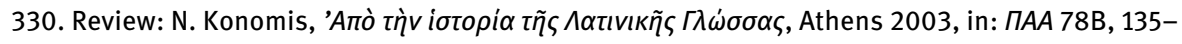
140.

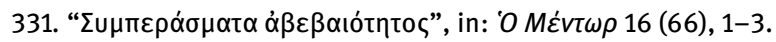

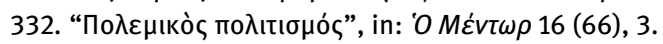

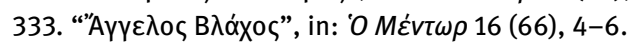

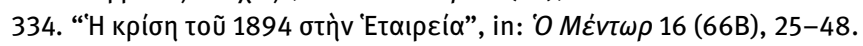

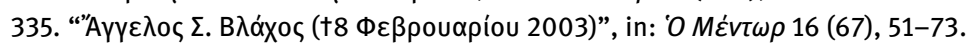

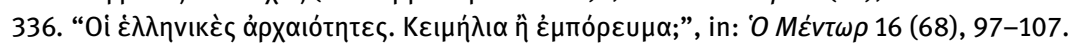

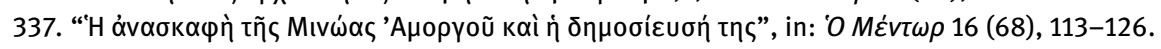

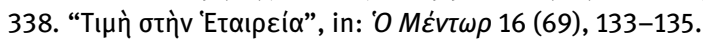

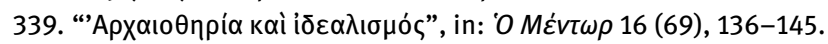


2003/2004

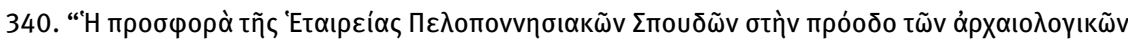

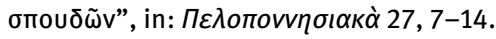

\section{4}

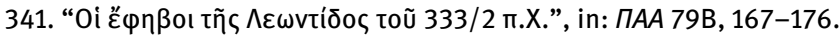

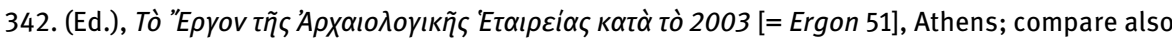
ПIE 158, 2003, $1 \alpha^{\prime}-1 \zeta^{\prime}$.

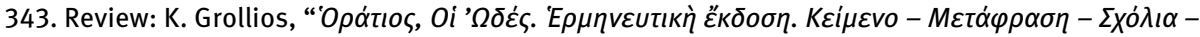

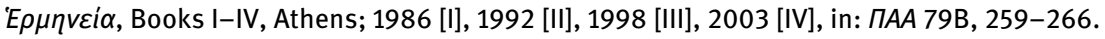

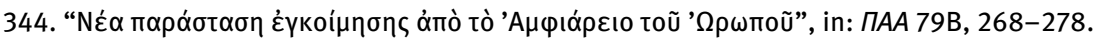

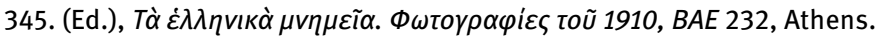

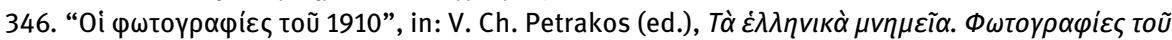
1910, BAE 232, Athens, $9 f$.

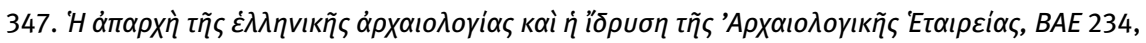
Athens = 'O MÉvt $\omega \rho 17$ (73), 111-222.

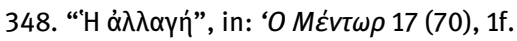

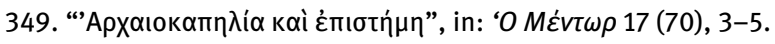

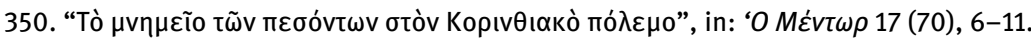

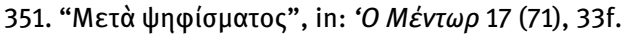

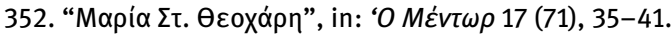

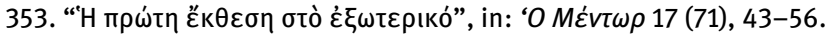

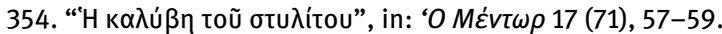

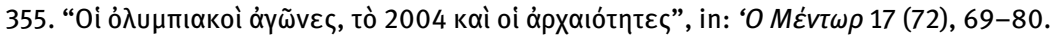

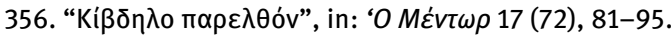

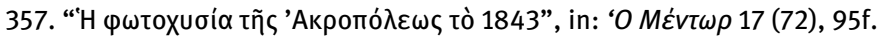

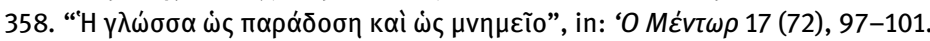

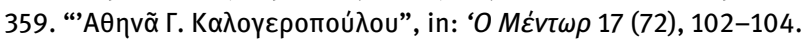

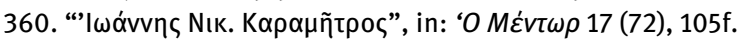

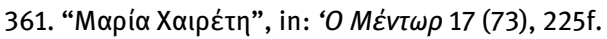

2005

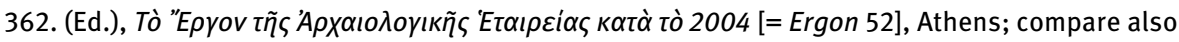
ПTE 159, 2004, $1 \alpha^{\prime}-1 \zeta^{\prime}$.

363. Review: S. lakovidis/E. B. French/K. Shelton/Ch. Ioannides/A. Jansen/J. Lavery, Archaeological Atlas of Mycenae, BAE 229, Athens 2003, in: ПAA 80B, 17-24.

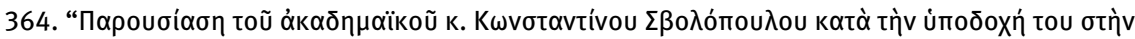

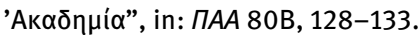

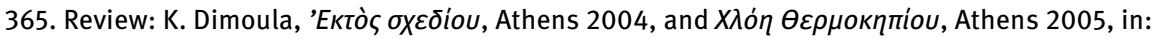
ПАА 80B, 155-164.

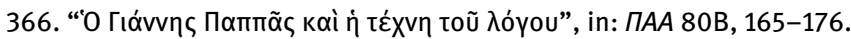

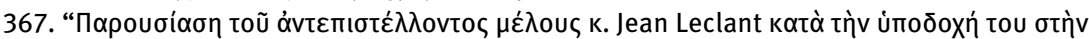

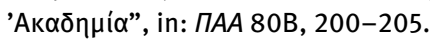

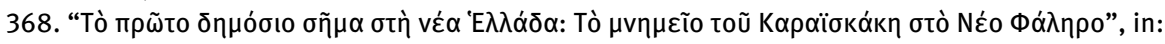
'O MÉvt $\omega \rho 18$ (74-75), 3-32.

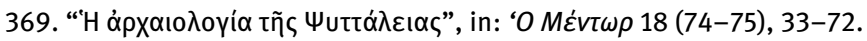

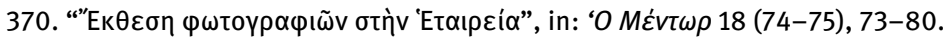

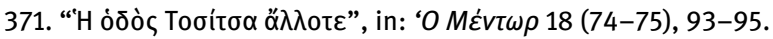

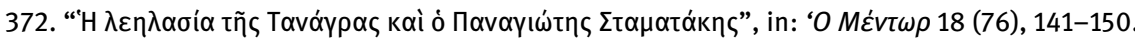




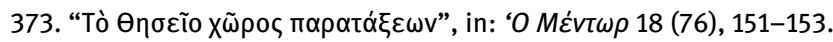

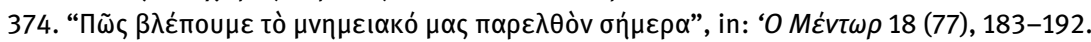

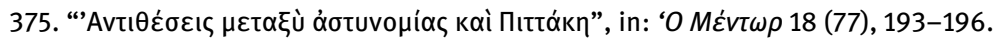

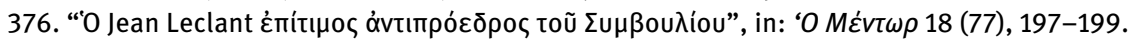

2006

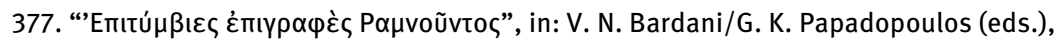

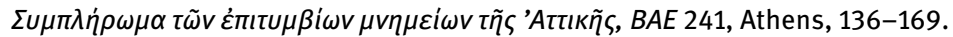

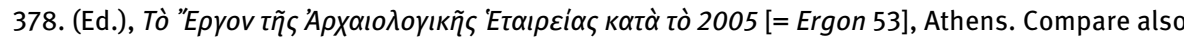
TAE 160, 2005, $1 \alpha^{\prime}-1 \eta^{\prime}$.

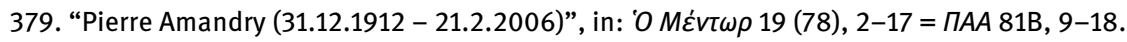

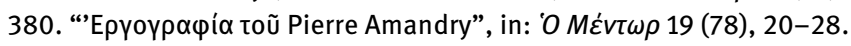

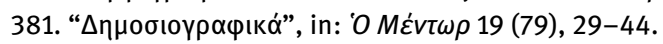

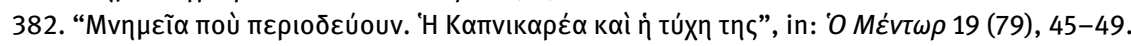

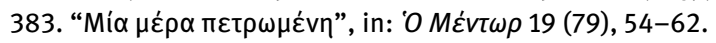

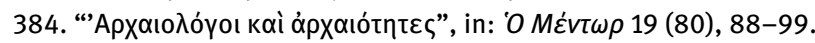

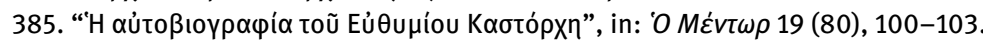

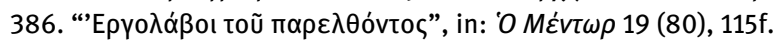

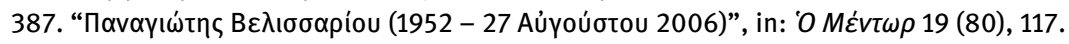

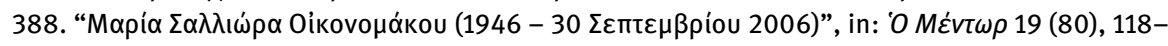
120.

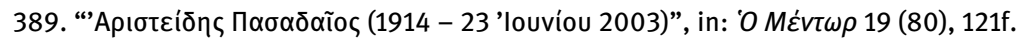

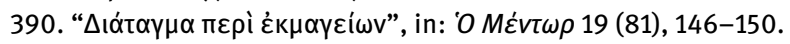

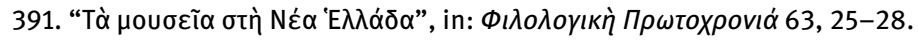

2007

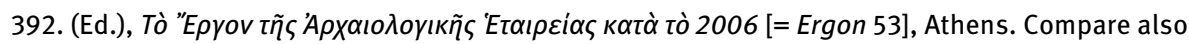
ПAE 161, 2006, $1 \alpha^{\prime}-1 \zeta^{\prime}$.

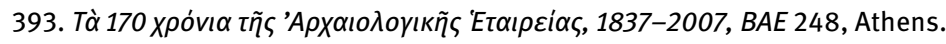

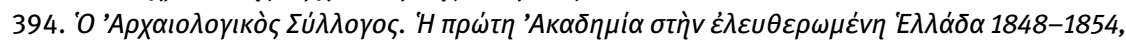
BAE 250, Athens.

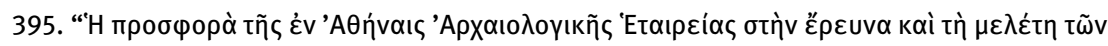

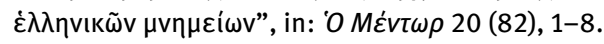

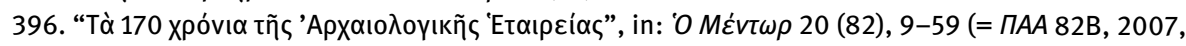
39-104).

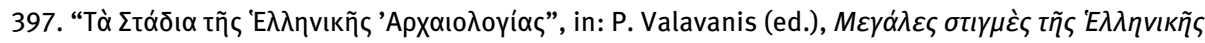
'Apxaıภoyias, Athens, 18-33. English edition: "The Stages of Greek Archaeology”, in:

P. Valavanis (ed.), Great Moments in Greek Archaeology, Los Angeles 2007, 16-33.

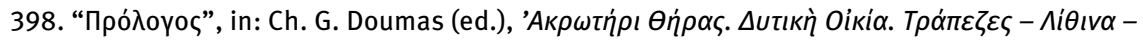

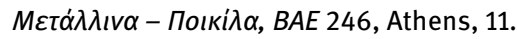

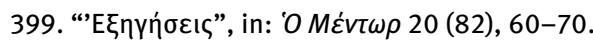

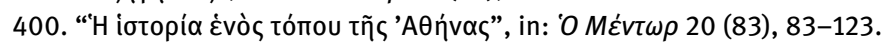

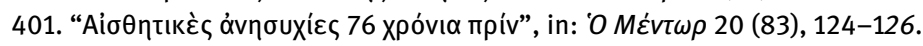

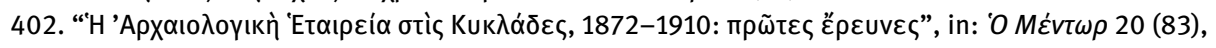
$135-141$.

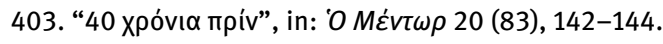

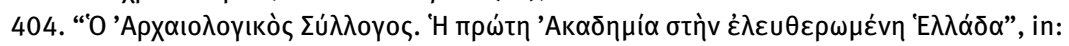

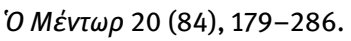

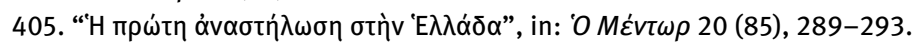




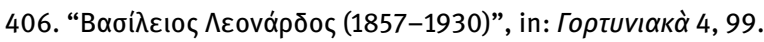

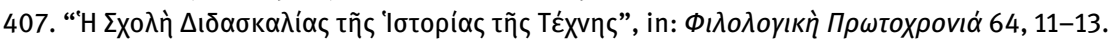

\section{8}

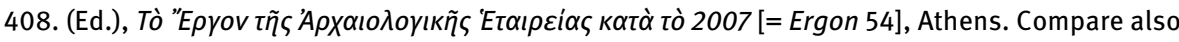
ПAE 162, 2007, $1 \alpha^{\prime}-\kappa \beta^{\prime}$.

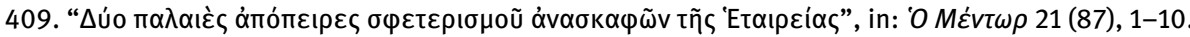

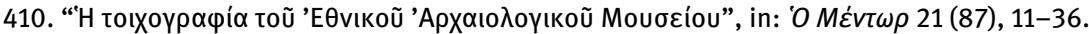

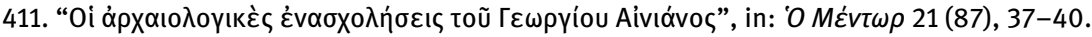

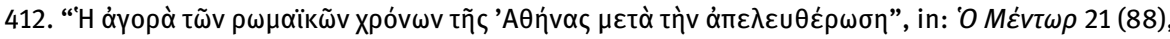
49-54.

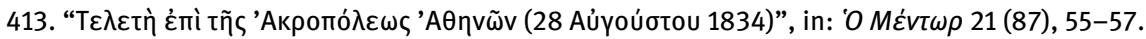

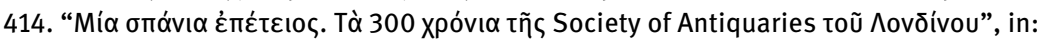

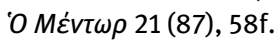

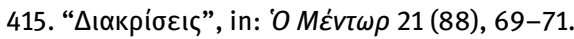

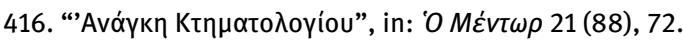

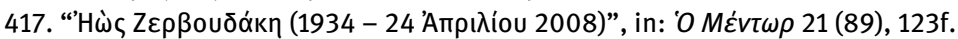

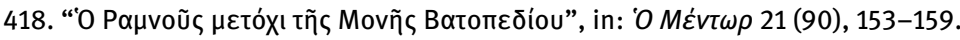

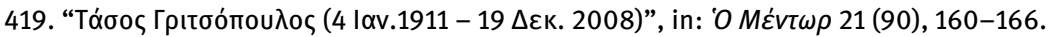

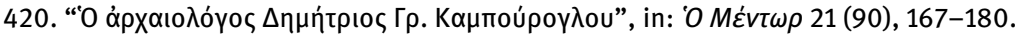

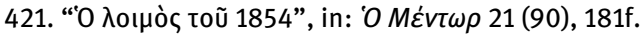

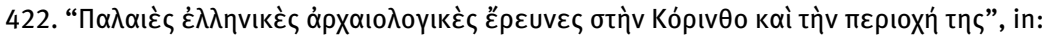

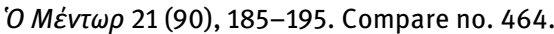

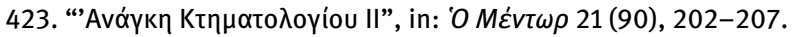

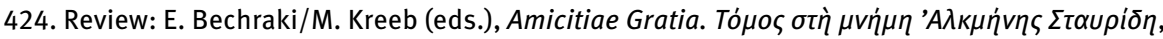
Athens 2008, in: 'O MÉvt $\omega \rho 21$ (90), 208-213.

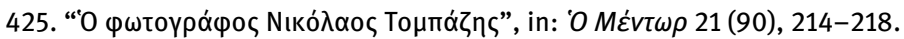

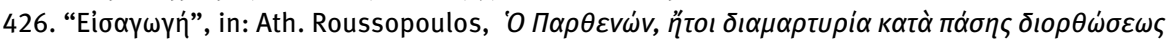

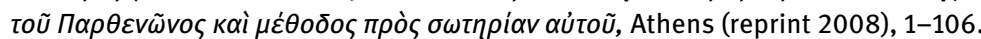

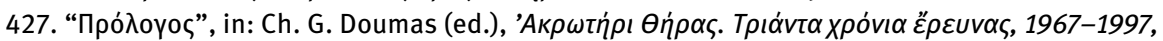

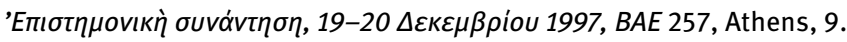

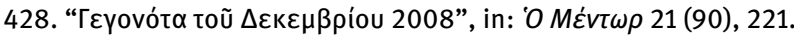

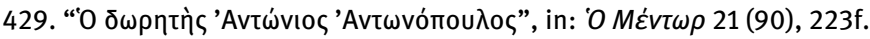

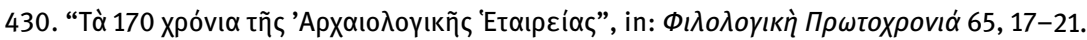

\section{9}

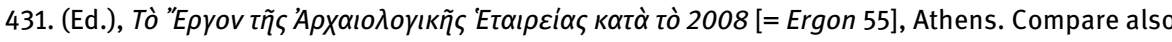
ПAE 163, 2008, $1 \alpha^{\prime}-1 \eta^{\prime}$.

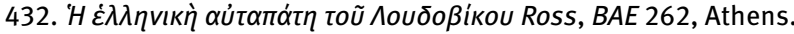

Review: K. Fittschen, Gnomon 88, 2016, 248-252.

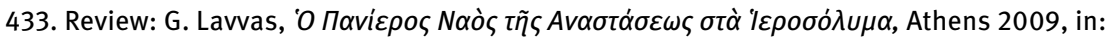

ПАА 84B, 35-45.

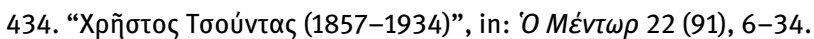

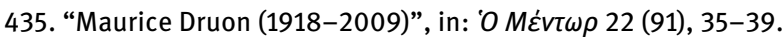

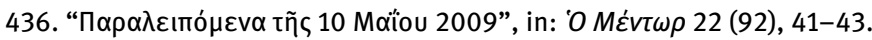

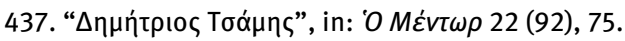

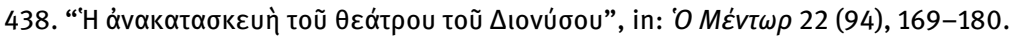

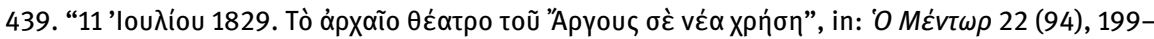
201. 


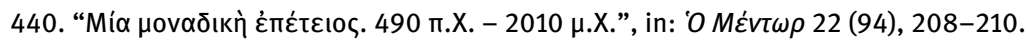

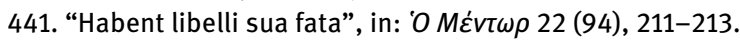

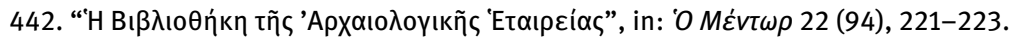

\section{0}

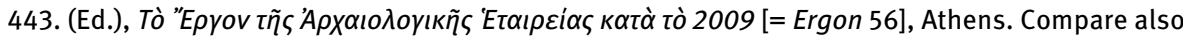
TAE 164, 2009, $1 \alpha^{\prime}-1 \zeta^{\prime}$.

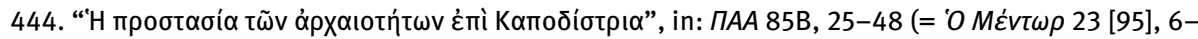
32)

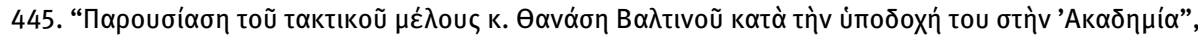
in: ПAA 85B, 141-146.

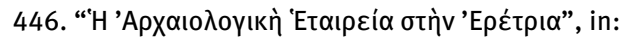

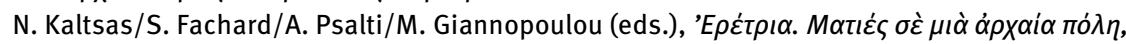

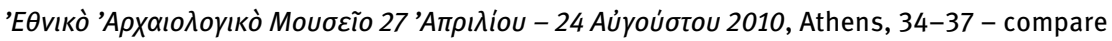
also the French and German translation in the Swiss edition. French: "La Société archéologique d'Athènes et ses recherches à Erétrie”, in: Ch. Martin Pruvot/K. Reber/Th. Theurillat (eds.), Cité sous terre. Des archéologues suisses explorent la cité grecque d'Érétrie, Catalogue de l'exposition réalisée par l'Ecole suisse d'archéologie en Grèce et l'Antikenmuseum Basel und Sammlung Ludwig, 22 septembre 2010 - 30 janvier 2011, Gollion Bâle, 37-39 - German: "Die Archäologische Gesellschaft Athens und ihre Forschungen in Eretria”, in: E. van der Meijden/K. Reber (eds.), Ausgegraben! Schweizer Archäologen erforschen die griechische Stadt Eretria. Eine Ausstellung der Schweizerischen Archäologischen Schule in Griechenland in Zusammenhang mit dem Antikenmuseum Basel und Sammlung Ludwig, 22 September 2010 - 30 Januar 2011, Basel, 37-39.

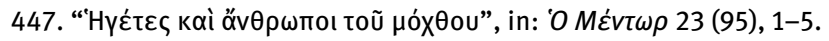

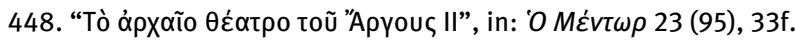

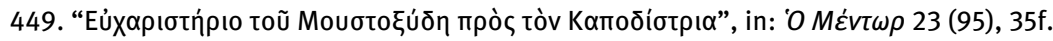

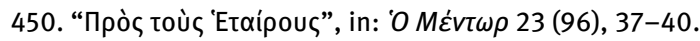

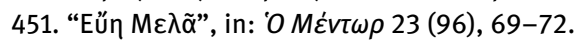

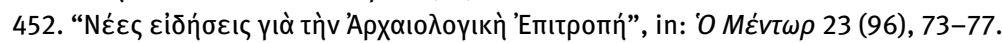

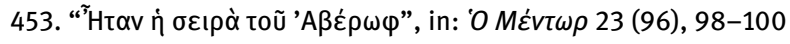

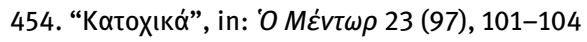

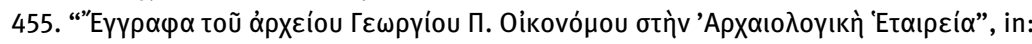

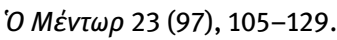

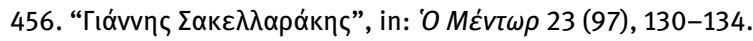

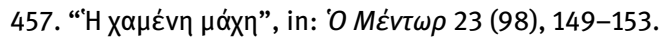

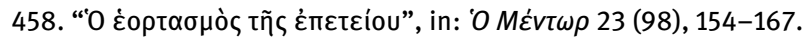

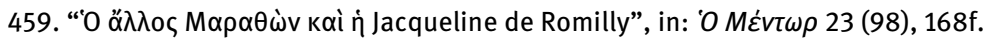

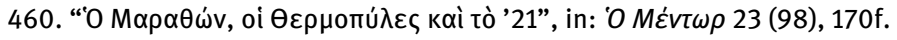

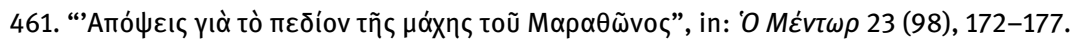

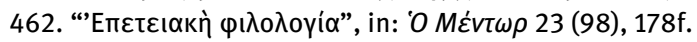

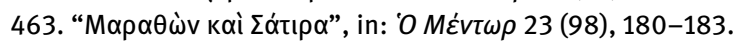

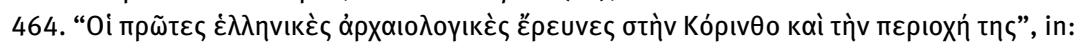

I. K. Giannaropoulou (ed.), Acts of the VIII International Congress of Peloponnesian Studies,

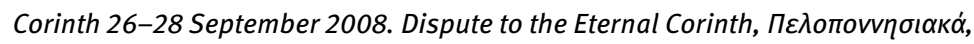

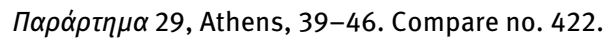


2011

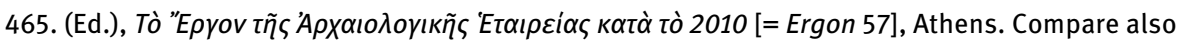

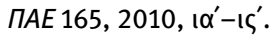

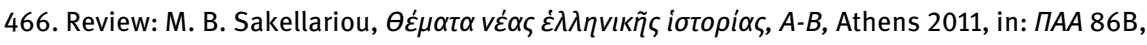
151-154.

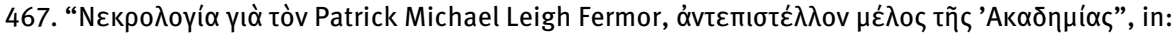
ПАА 86B, $155 \mathrm{f}$.

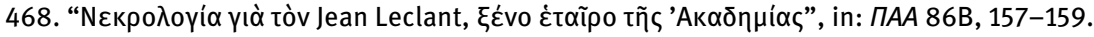

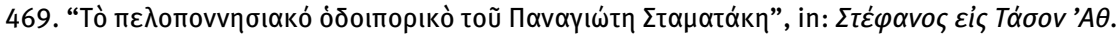

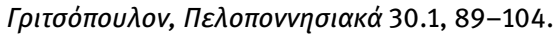

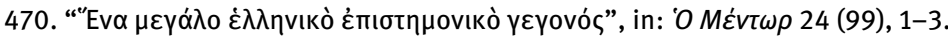

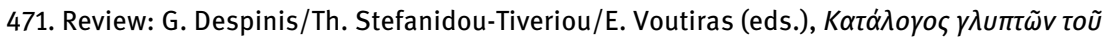

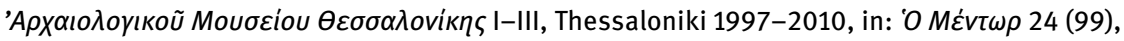
6-8.

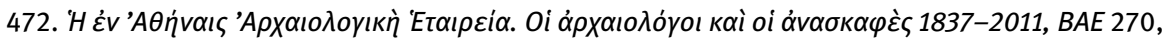

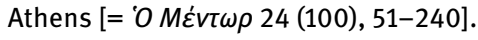

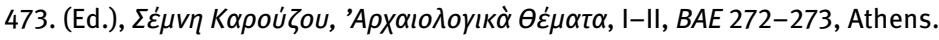

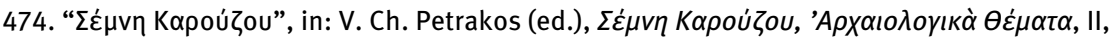
$B A E$ 273, Athens, XI-XV.

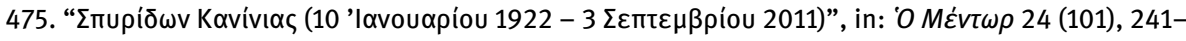
252.

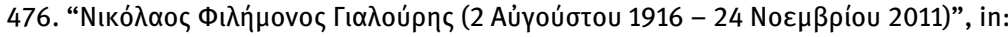

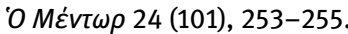

477. “Ф

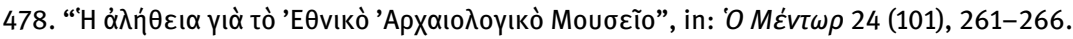

2012

479. (Ed.), Tò ”E ПAE 166, 2011, $\iota \alpha^{\prime}-1 \delta^{\prime}$.

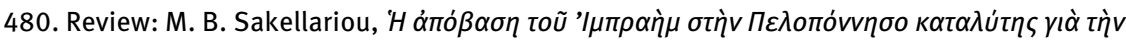

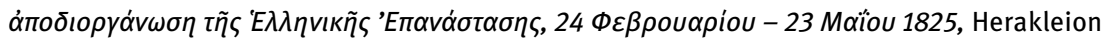
2012, in: ПАA 87B, 37-41.

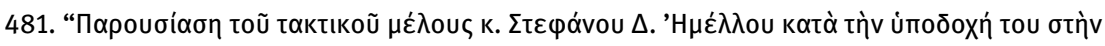

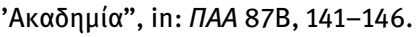

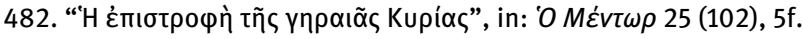

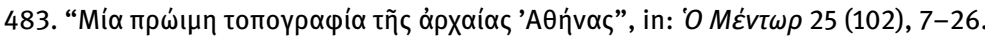

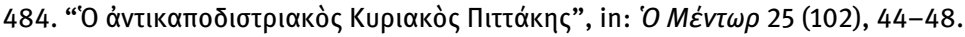

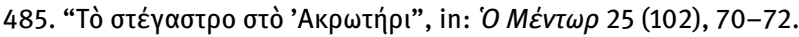

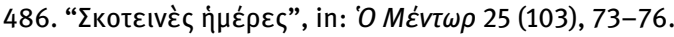

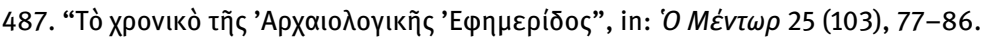

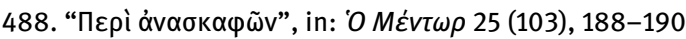

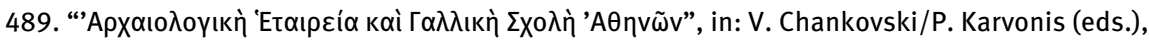
Tout vendre, tout acheter: structures et équipements des marchés antiques. Actes du colloque d'Athènes, 16-19 juin 2009, Ausonius Scripta Antiqua 42, Bordeaux, $9 f$.

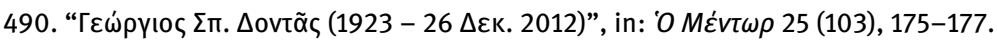

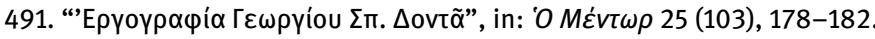


2013

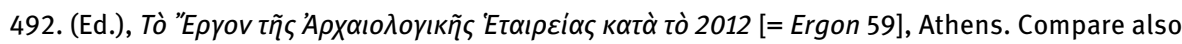
ПAE 167, 2012, เ $\alpha^{\prime}-ı \varsigma^{\prime}$.

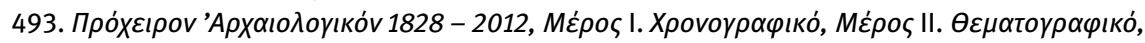
BAE 283-284, Athens.

Reviews: C. Souyoudzoglou-Haywood, BMCR 2015.02.34; R. Stupperich, Thetis 21, 2015, 269272.

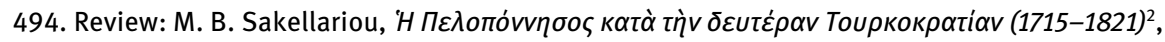
Athens 2012, in: ПАA 88B, 91-99.

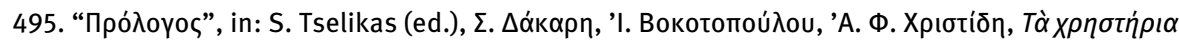

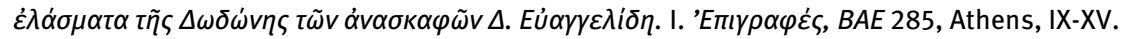

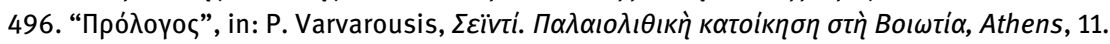

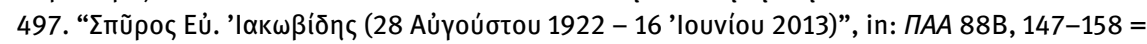

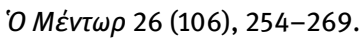

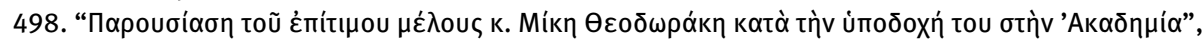
in: ПАA 88B, 209-213.

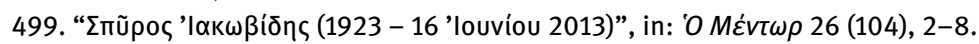

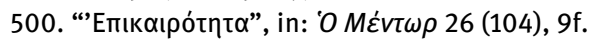

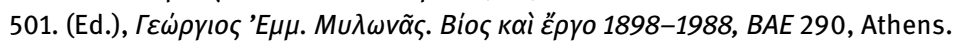

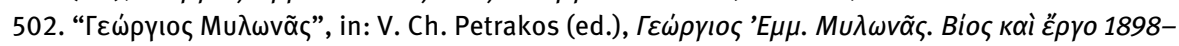

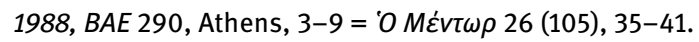

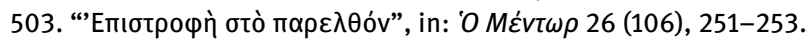

\section{4}

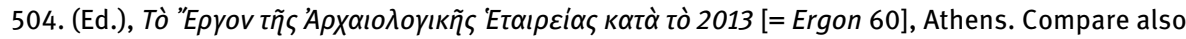
$\Pi A E$ 168, 2013, เ $\alpha^{\prime}-ı \varsigma^{\prime}$.

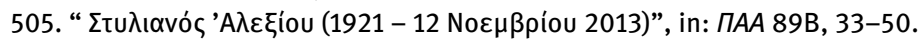

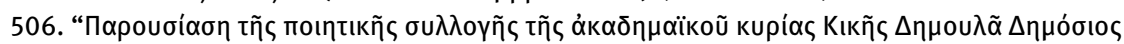
Kaıpós”, in: ПАA 89B, 33-50.

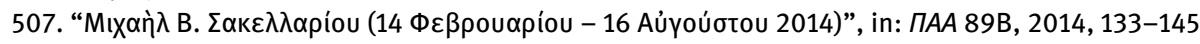
= $O$ M $\varepsilon^{\prime} v t \omega \rho 27$ (110), 336-353.

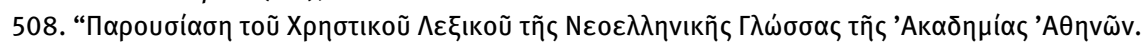

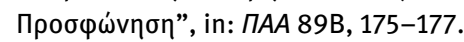

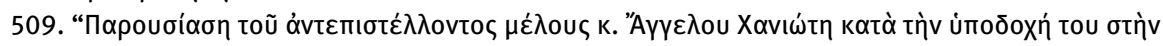

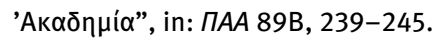

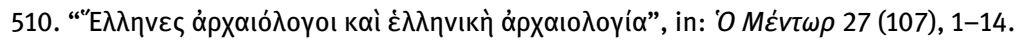

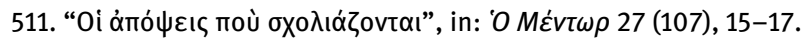

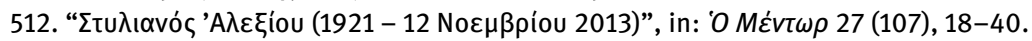

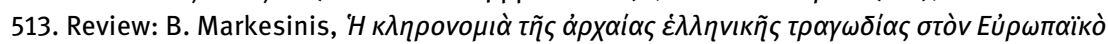

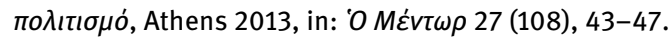

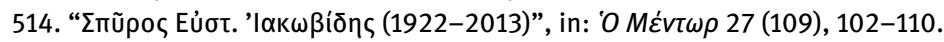

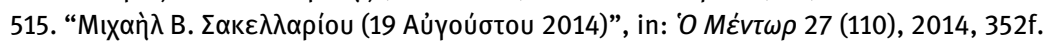

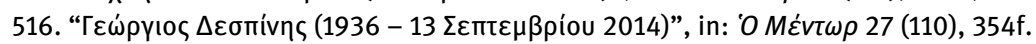

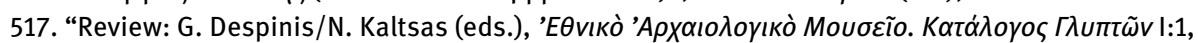

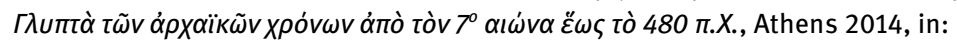

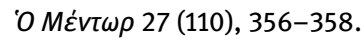

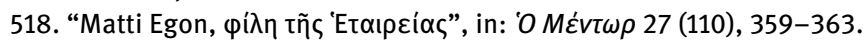

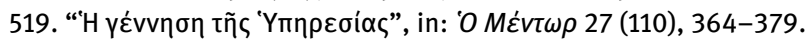

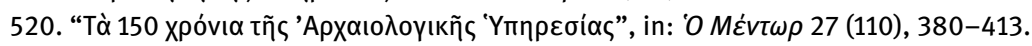




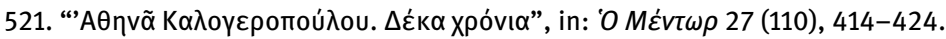

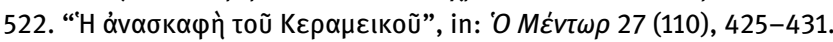

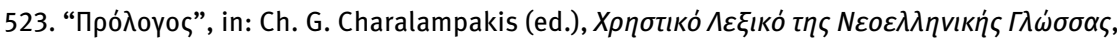
Athens, 7.

524. "Editor's preface", in: M. B. Cosmopoulos, The Sanctuary of Demeter at Eleusis. The Bronze Age. I, BAE 295, Athens, XII-XIV.

2015

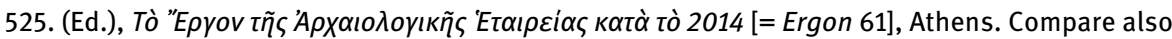
ПАE 169, 2014, $\theta^{\prime}-1 \delta^{\prime}$.

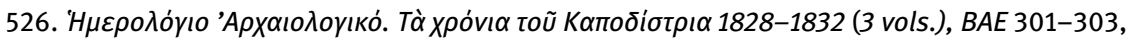
Athens.

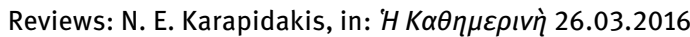

(https://www.kathimerini.gr/854290/article/politismos/vivlio/h-anoloklhrwth-sxesh-me-thnarxaiothta); N. Papalexandrou, in: BMCR 2016.10.15.

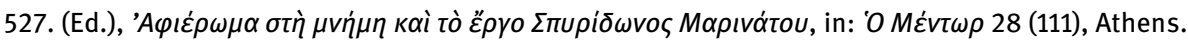

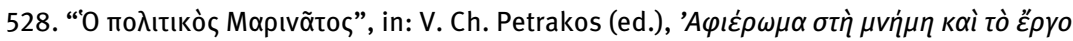

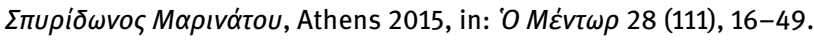

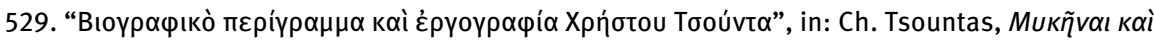

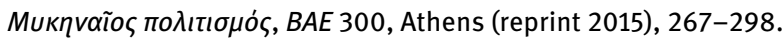

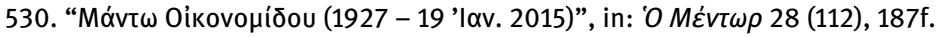

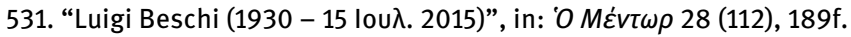

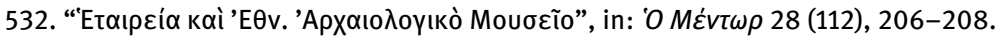

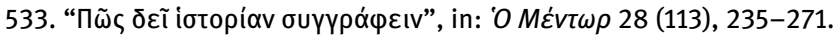

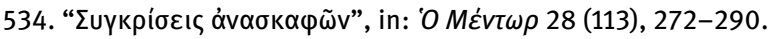

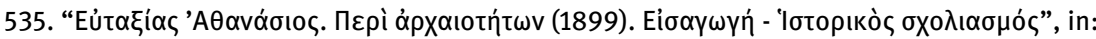

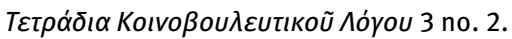

2016

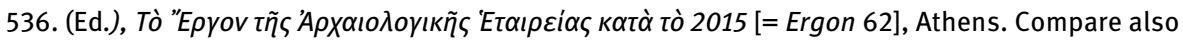
חAE 170, 2015, $\theta^{\prime}-1 \alpha^{\prime}$.

537. "Presentation of: Nanno Marinatos, Sir Arthur Evans and Minoan Crete. Creating the Vision of

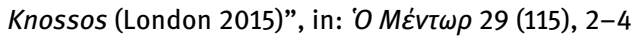

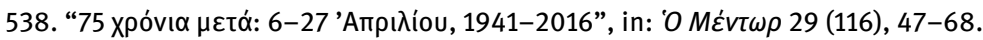

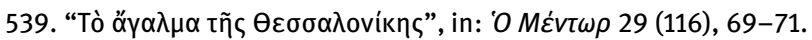

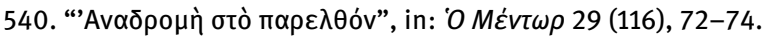

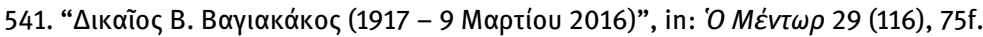

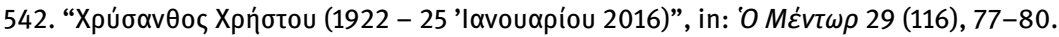

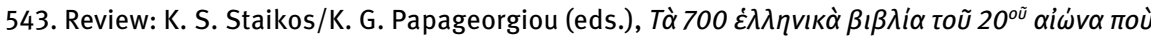

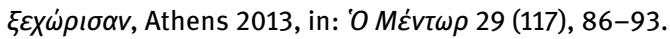

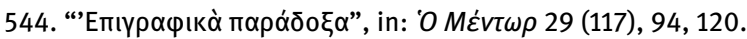

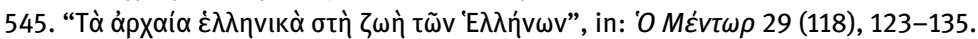

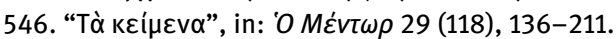

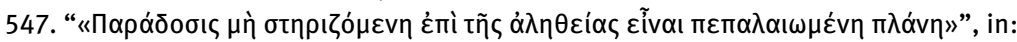

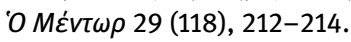

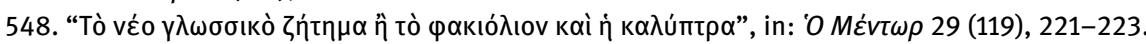

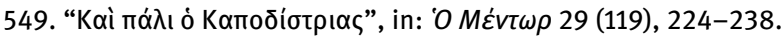

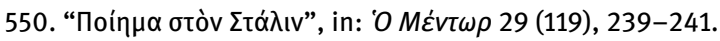

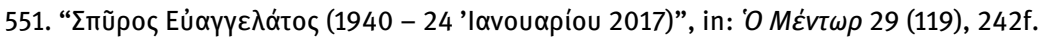




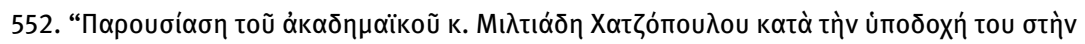

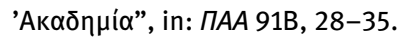

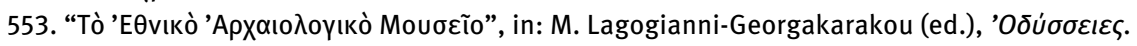

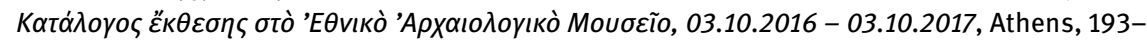
196.

2017

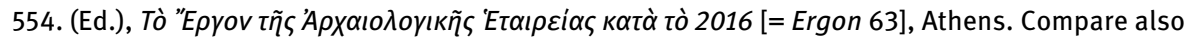
חAE 171, 2016, $\theta^{\prime}-1 \beta^{\prime}$.

555. Robert McCabe. Chronography. 180 Years Archaeological Society. Commentary by Vasileios Petrakos, Athens. Bilingual (Greek and English) edition.

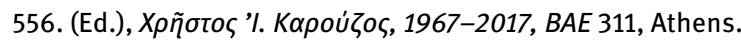

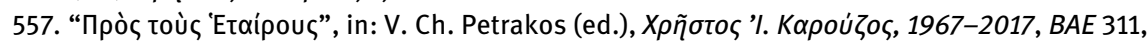
Athens, 1.

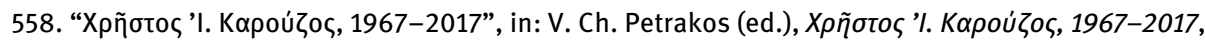
BAE 311, Athens, 159-184.

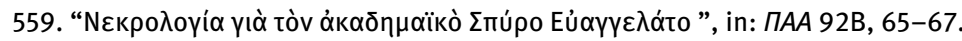

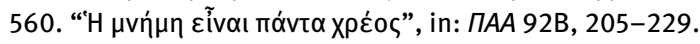

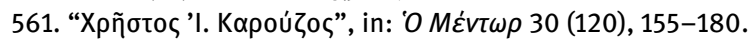

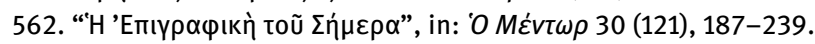

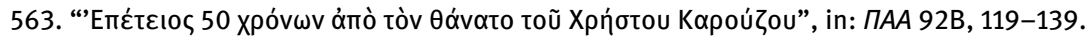

564. “"Аv $\triangle \eta \mu$ ou $\tilde{\alpha}^{\prime \prime}$, in: ПAA 92B, 189-202.

\section{8}

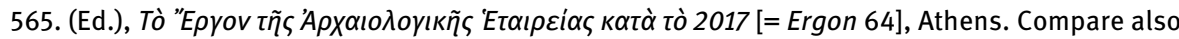
ПAE 172, 2017, $\theta^{\prime}-1 \beta^{\prime}$.

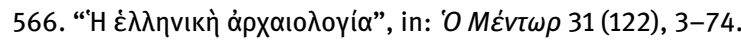

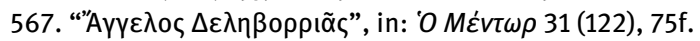

568. “Panagiotis Stamatakis. Hüter des Gesetzes”, in: Badisches Landesmuseum Karlsruhe (ed.), Mykene. Die sagenhafte Welt des Agamemnon, Darmstadt, 27-29.

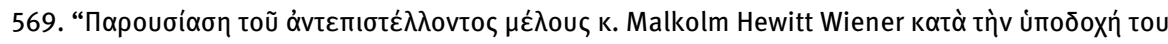

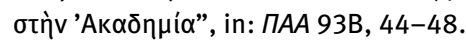

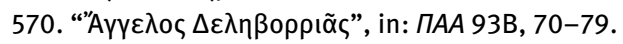

2019

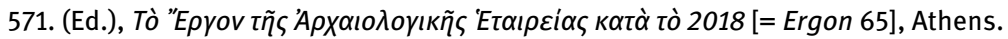

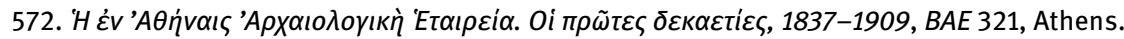

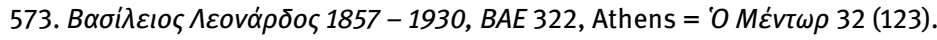

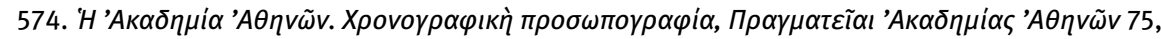
Athens.

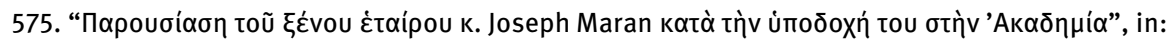
ПАА 94В, 86-90.

576. “Oi đ̊̉

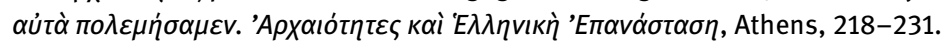

\section{0}

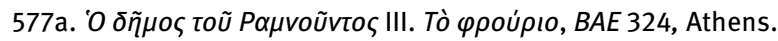

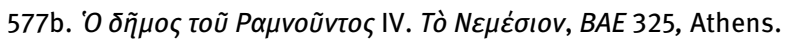




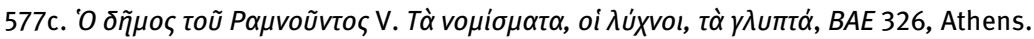

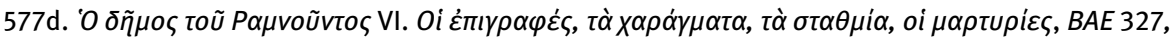
Athens.

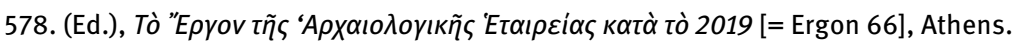

\section{Forthcoming}

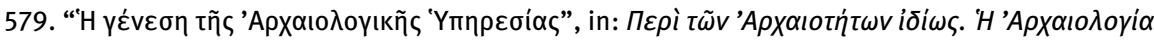

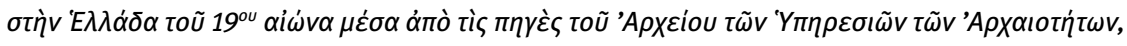

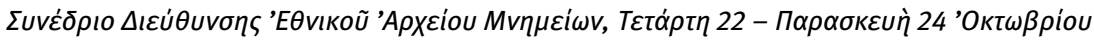

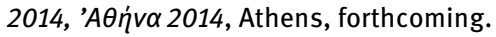

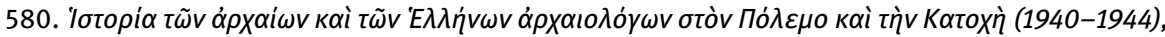
Athens, forthcoming.

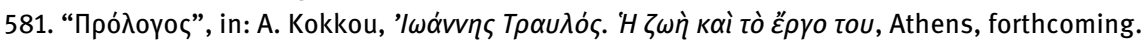

\section{Bibliography}

Doukellis, P.N. (1998), “V. Petrakos, Les inscriptions d'Oropos”, in: Dialogues d'histoire ancienne, 24:2, 162.

Dürrbach, F. (1890), De Oropo et Amphiarai sacro, Parisiis.

Habicht, Ch. (1998), "Recent Activities at Rhamnous", in: AJA 102, 388.

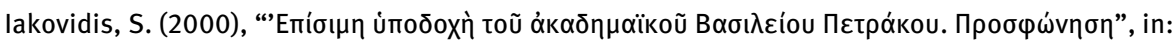
ПАА 75B, 556-558.

Jameson, M.H. (1999), “Inscriptions from Cos and Oropus", in: CPhil 94, 321-324.

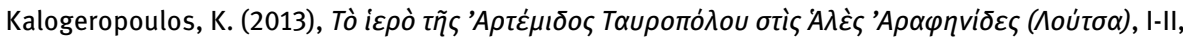

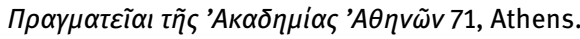

Ma, J. (2008), “The Return of the Black Hunter”, in: Cambridge Classical Journal 54, 188-208.

Nawracala, R. (2014), Das Thesmophorion von Rhamnous, Hamburg.

Oetjen, R. (2014), Athen im dritten Jahrhundert v. Chr. Politik und Gesellschaft in den Garnisonsdemen auf der Grundlage der inschriftlichen Überlieferung, Duisburg.

Oliver, G.J. (2002), “Callimachus the Poet and Benefactor of the Athenians", in: ZPE 140, 6-8.

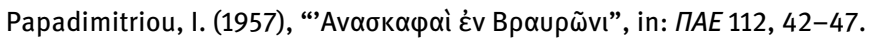

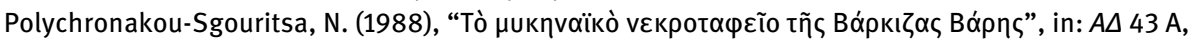
1-106.

Raubitschek, A. E (1964), “Die Inschrift als Denkmal. Bemerkungen zur Methodologie der Inschriftenkunde”, in: Studium Generale 17, 219-228. 